\title{
DESIGN OF WASTEWATER TREATMENT PLANT AND NUTRIENTS RECOVERY
}

By

Ashish Kumar Gupta

Bachelor of Engineering 1994, University of Bombay

A MRP presented to Ryerson University

in partial fulfilment of

the requirements for the degree of

Master of Engineering

in the Program of

Civil Engineering

Toronto, Ontario, 2016

(C) Ashish Kumar Gupta 2016 
Author's Declaration

I hereby declare that I am the sole author of this MRP. This is a true copy of the MRP, including any required final revisions.

I authorize Ryerson University to lend this MRP to other institutions or individuals for the purpose of scholarly research.

I further authorize Ryerson University to reproduce this MRP by photocopying or by other means, in total or in part, at the request of other institutions or individuals for the purpose of scholarly research.

I understand that my MRP may be made electronically available to the public. 


\title{
DESIGN OF WASTEWATER TREATMENT PLANT AND NUTRIENTS RECOVERY
}

\author{
Ashish Kumar Gupta, 2016 \\ Master of Engineering \\ Department of Civil Engineering \\ Ryerson University
}

\begin{abstract}
The objective was to design a municipal wastewater treatment plant with primary sedimentation and without primary sedimentation and then compare the savings in capital cost. The project discussed the design procures for the various units such as preliminary units, secondary units and tertiary units. The parametric cost estimation concept is utilized to arrive at the capital cost savings. The literature review includes the various methods to recover the nutrients from the wastewater. The literature review also includes various measures to be taken for performance improvement of municipal wastewater treatment plants. This project concludes that capital cost savings of about twenty percent can be achieved by not providing the primary sedimentation.
\end{abstract}


Acknowledgements

I wish to thank Dr. Elsayed Elbeshbishy for his guidance on this project. He also provided valuable insight and encouragement from time to time. Without the guidance of my supervisor, this task would have taken more time and the quality of work would have not have been as presented in this project. I also thank the Ryerson Civil Engineering Department for providing the required resources to accomplish this work. 


\section{Contents}

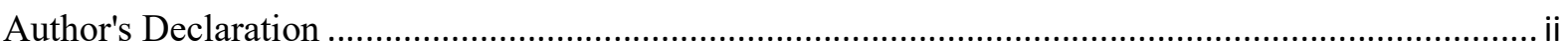

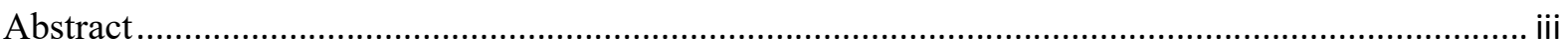

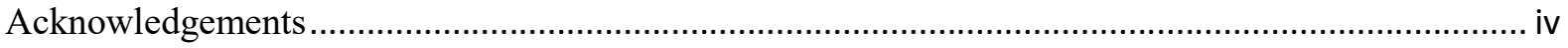

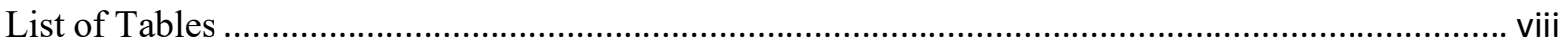

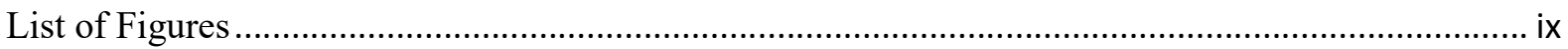

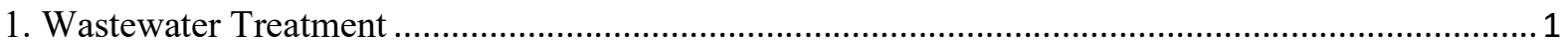

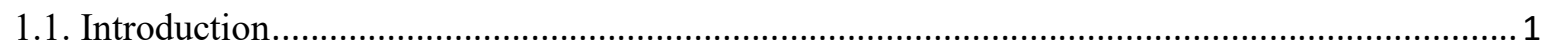

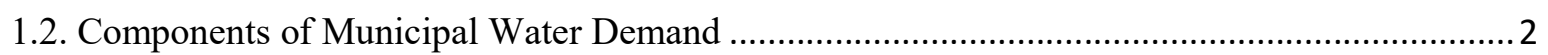

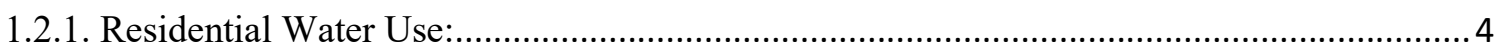

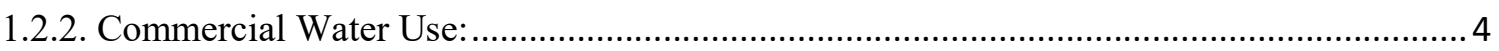

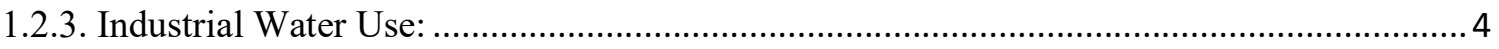

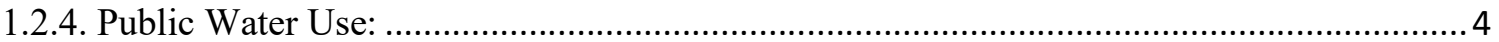

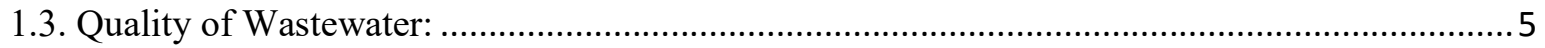

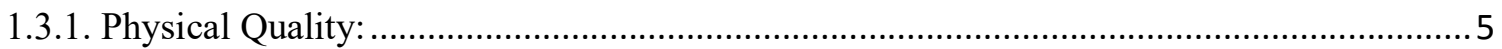

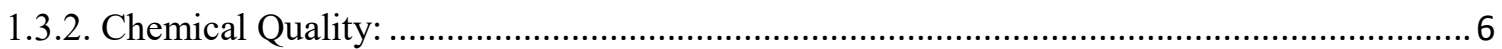

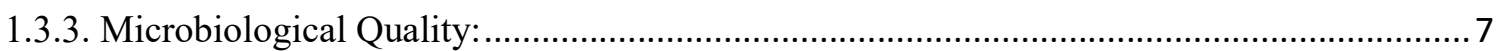

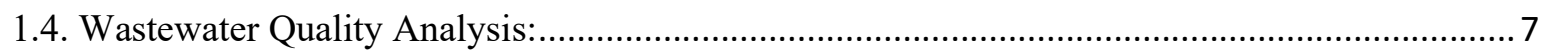

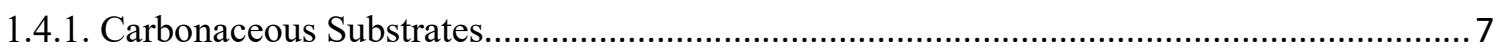

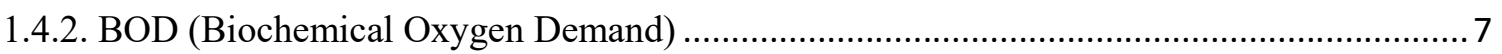

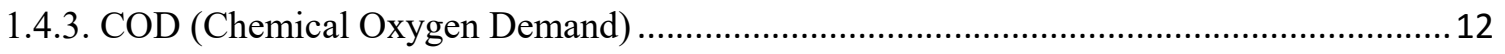

2. Wastewater Collection Systems ................................................................................................ 14

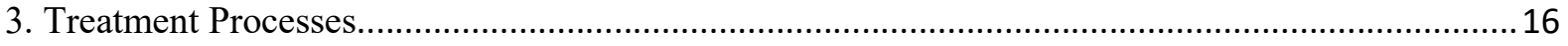

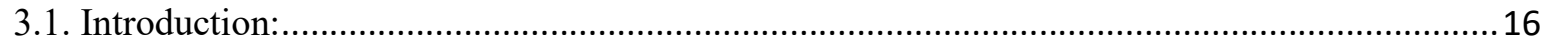

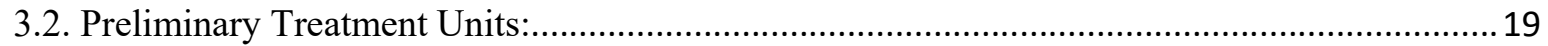

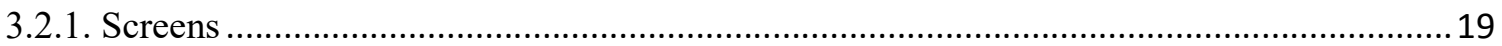

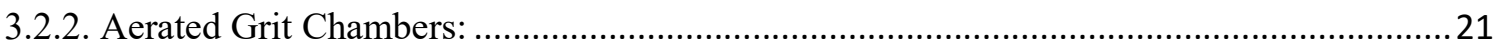

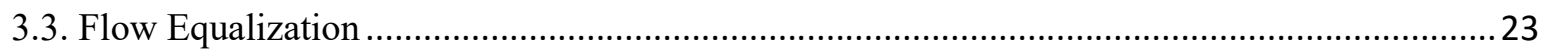

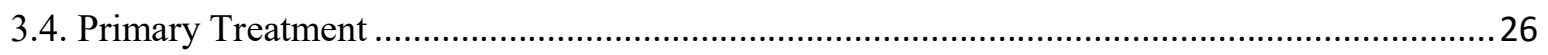

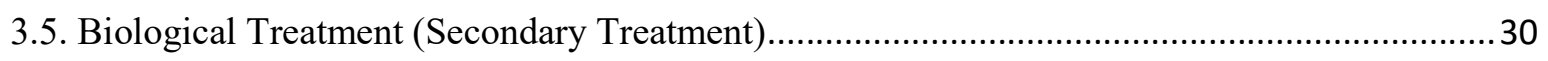

3.5.1. Activated Sludge Process .............................................................................................. 30

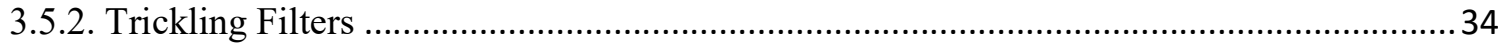




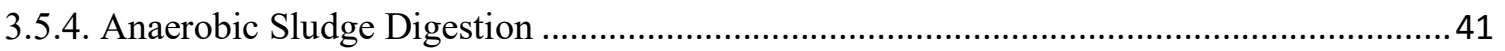

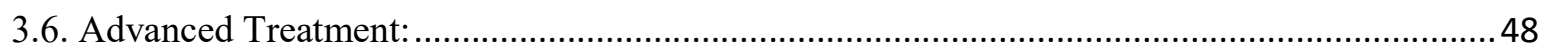

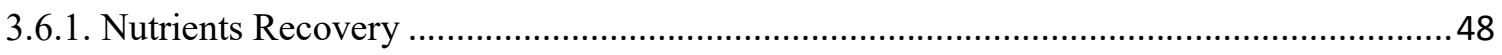

3.6.2. Phosphorous Recovery from Sludge Originating from a Biological Process ...................... 53

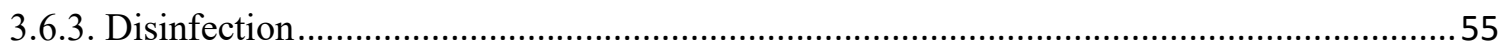

4. Optimization Opportunities Through Process Modifications .......................................................5 57

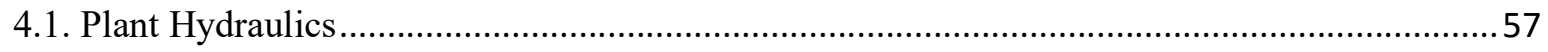

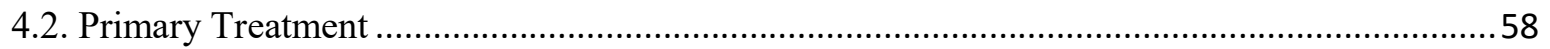

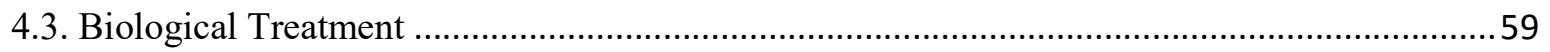

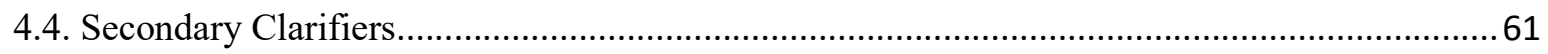

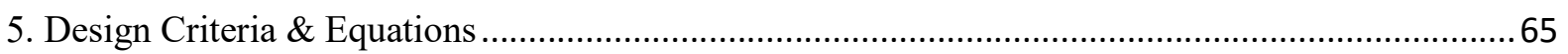

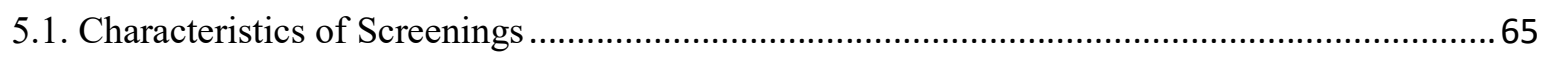

5.2. Typical Design Criteria for Aerated Grit Chamber are:.........................................................67

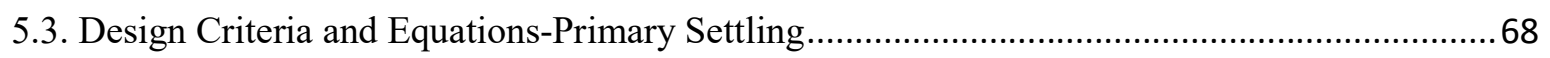

5.4. Design Criteria and Equations-Secondary Treatment (General) (Elbeshbishy, 2016) .............69

5.5. Conventional Activated Sludge Process ……...................................................................... 71

6. Design Calculations with Primary Sedimentation ……................................................................ 75

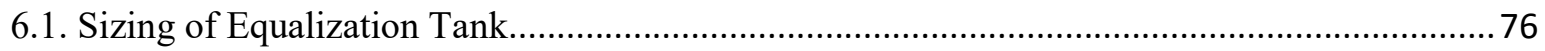

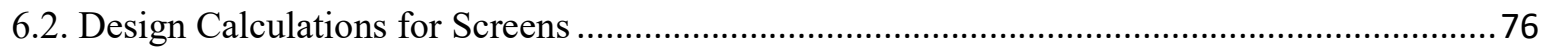

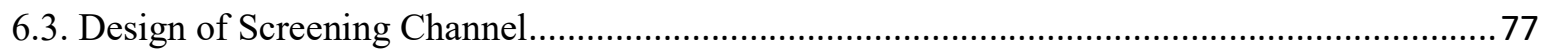

6.4. Design Calculation for Aerated Grit Chamber....................................................................... 77

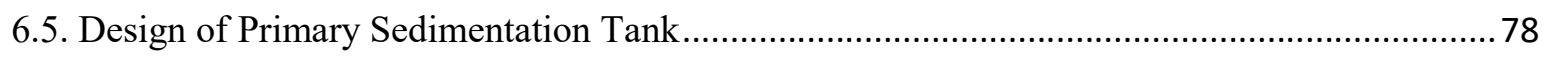

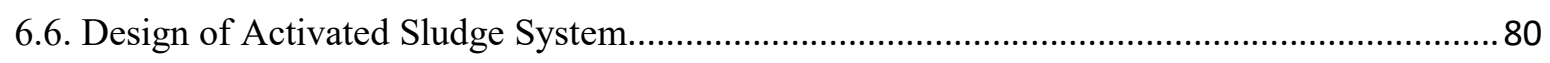

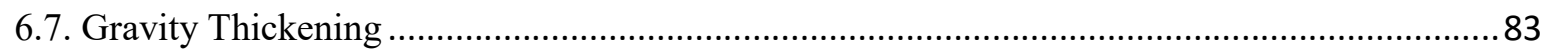

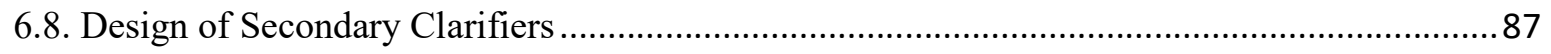

6.9. Design of Continuous Stirred Tank Reactor (CSTR) Digester .................................................90

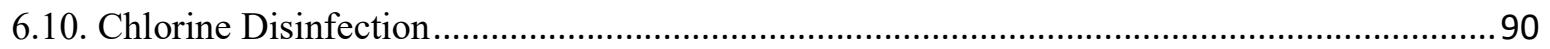

6.11. Drawings of the Treatment Units (Dimensions in milimetres) ................................................95

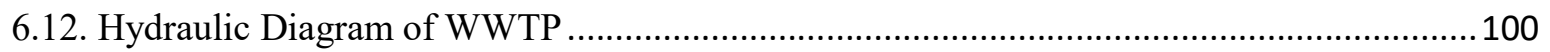

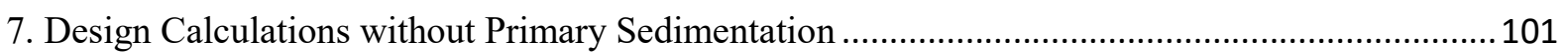

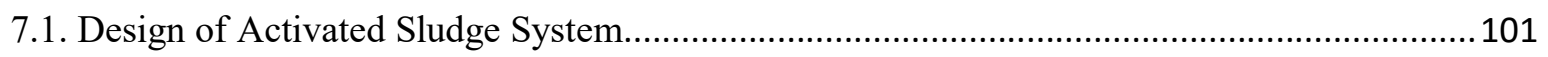

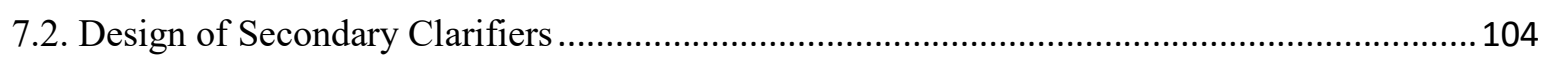

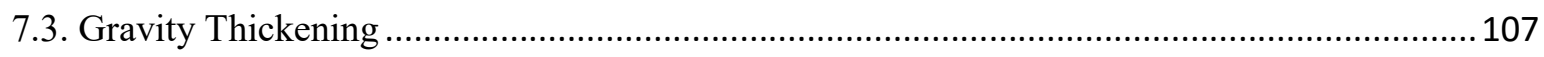


7.4. Design of Continuous Stirred Tank Reactor (CSTR) Digester

7.5. Chlorine Disinfection

7.6. Drawings of the Treatment Units (Dimensions in millimetres) 112

7.7. Hydraulic Diagram of WWTP (without Primary Sedimentation) 114

8. Establishing the Percent Capital Cost Savings Using the Technique of Parametric Estimation ....115

8.1. Parametric Estimation Concept \& Formulation. 115

8.2. Computing the Volume of the Units with Primary Sedimentation 117

8.3. Computing the Volume of the Units with Primary Sedimentation 117

8.4. Computing the Percent Capital Cost Savings 118

9. Conclusion 119

References. 120 


\section{List of Tables}

Table 1: Shows Major Pollutants in Wastewater and Their Impacts (Elbeshbishy, 2016)................... 3

Table 2: Characteristics of Typical Domestic Wastewater (Elbeshbishy, 2016) .................................. 6

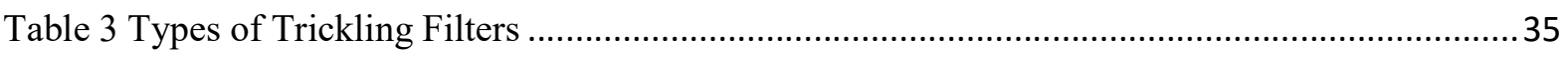

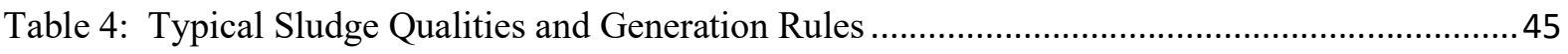

Table 5: Mechanisms of Phosphorous Recovery (Federation of Canadian Municipalities and National

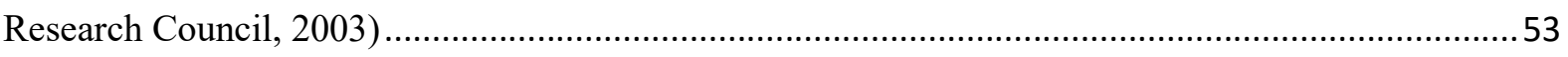

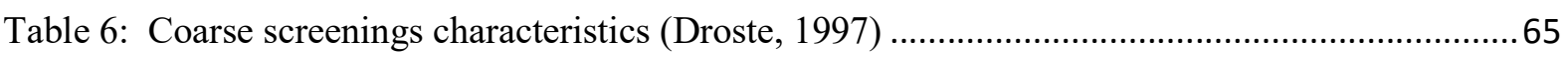

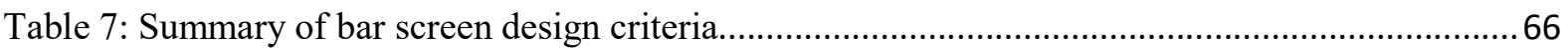

Table 8: Design factors for manually and mechanically cleaned bar racks .......................................67

Table 9: Design Criteria Typically Used for Primary Settling Tank. .................................................. 68

Table 10: Surface Loading Rates and Solid Concentration Typically Achieved in Thickeners...........85

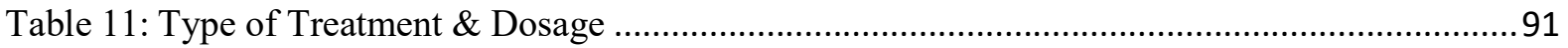

Table 12: Surface Loading Rates and Solid Concentration Typically Achieved in Thickeners.........109

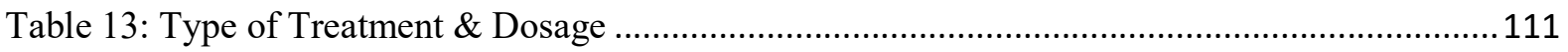

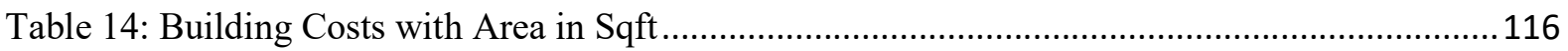

Table 15: Computation Showing the Volume with Primary Sedimentation.......................................117

Table 16: Computation Showing the Volume Without Primary Sedimentation................................117 


\section{List of Figures}

Figure 1: Shows Major Contaminants in Wastewater (Elbeshbishy, 2016) ....................................... 3

Figure 2: Typical Components of Wastewater Flow from Community (Elbeshbishy, 2016) ............. 4

Figure 3: A typical set-up for BOD measurement (www.hach.com).................................................

Figure 4: Ultimate BOD Estimation Using Long Term Incubation.................................................. 10

Figure 5: BOD Remaining with Incubation Time. (Elbeshbishy, 2016) ………...............................12

Figure 6: Typical COD Fractionation (Elbeshbishy, 2016) ……………………............................13

Figure 7: (A) Separate Sewer System, (B) Combined Sewer System (Elbeshbishy, 2016) .................14

Figure 8: Typical Steps in Wastewater Treatment (Elbeshbishy, 2016).............................................18

Figure 9: Typical Municipal Wastewater Treatment Process (Elbeshbishy, 2016) ............................18

Figure 10: (A) Schematic of a Typical bar Screen used in wastewater treatment plant (source

water.me.vccs.edu) (B) photograph of a bar screen (http://www.infobarscreens.com/bar-screen.jpg) 20

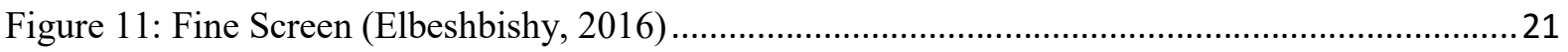

Figure 12: Shows Manual \& Mechanized Screen Cleaning (Indian Institute of Technology, India,

$2016)$

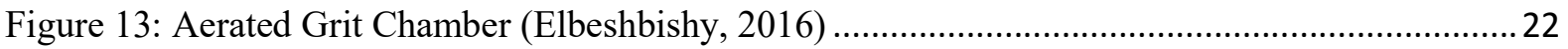

Figure 14: Sutro Weir (Ministry of Enviornment -Ontario, 2008) ...................................................23

Figure 15: Types of Flow equalization (A) inline, (B) Side-line (Elbeshbishy, 2016) ........................24

Figure 16: Design of Flow Equalization Basin (Elbeshbishy, 2016) ................................................25

Figure 17: Rectangular Sedimentation Tank (Ministry of Enviornment -Ontario, 2008) ...................27

Figure 18: Rectangular Clarifier with Zones (Elbeshbishy, 2016) ....................................................29

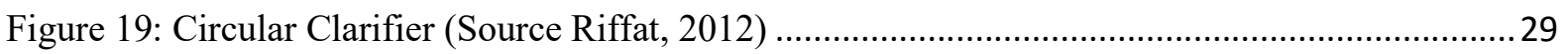

Figure 20: Activated Sludge Process (Indian Institute of Technology, India , 2016) ...........................30

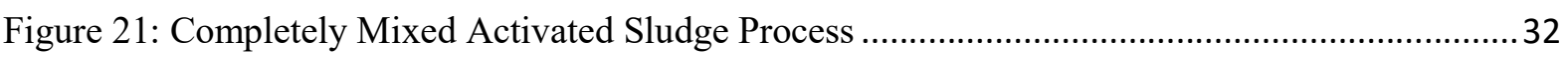

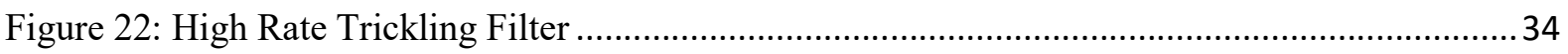

Figure 23: Flow Sheet of a Trickling Filter System (Indian Institute of Technology, India , 2016) ....36

Figure 24: Symbiotic Relationship and Functioning of Facultative Stabilization Pond (Indian Institute

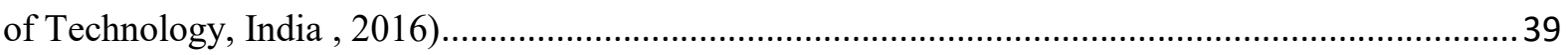

Figure 25: The Three Main Steps in Nutrient Recovery and Reuse (Federation of Canadian

Municipalities and National Research Council, 2003)

Figure 26: Potentially Recoverable Phosphorous at Various Points in a Typical WWTP (Federation of Canadian Municipalities and National Research Council, 2003) .50

Figure 27: Potentially Recoverable Nitrogen at Various Points in a Typical WWT (Federation of Canadian Municipalities and National Research Council, 2003) 
Figure 28: Options for Nutrient Recovery

Figure 29: Schematic of the Lystek Process- Developed after Singh el al. 2006 and Janssens 2014 ...54

Figure 30: Schematic of an Established Process of Alkalinity Addition-the N-Viro Process

(Federation of Canadian Municipalities and National Research Council, 2003). .54

Figure 31: An Emerging Technology: VitAG Process Producing Ammonium Sulfate -Developed

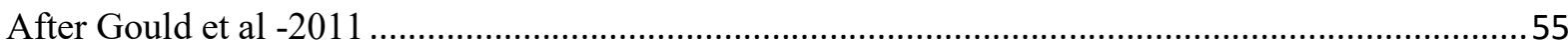

Figure 32: Schematic of a UV Disinfection Chamber (Elbeshbishy, 2016) ........................................56

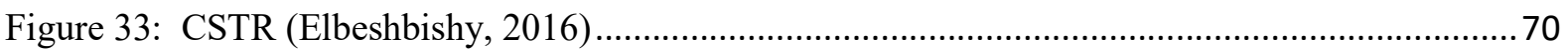

Figure 34: Activated Sludge Process (Elbeshbishy, 2016) .............................................................. 71

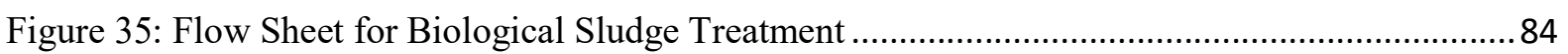

Figure 36: Above Shows Plan \& Section Through Equalization Tank..............................................95

Figure 37: Above Shows Plan and Section for Screening Channel ...................................................95

Figure 38: Above Shows Plan \& Section for Grit Chamber...............................................................96

Figure 39: Above Shows Plan \& Section for Primary Sedimentation Tank ........................................96

Figure 40: Figure Above Shows Plan \& Section of Aeration Tank....................................................97

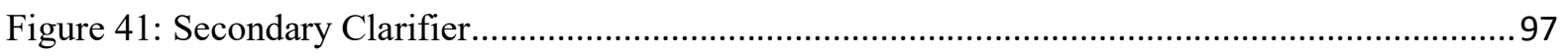

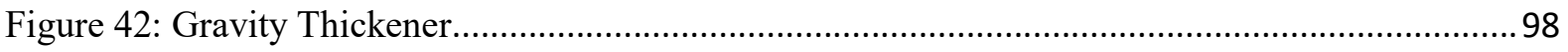

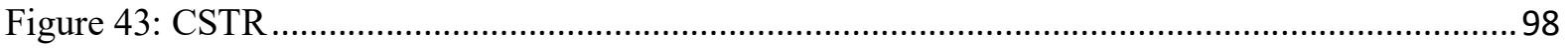

Figure 44: Plan Showing Chlorination Tank ………….................................................................... 99

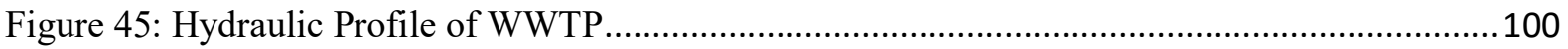

Figure 46: Flow Sheet for Biological Sludge Treatment .............................................................. 107

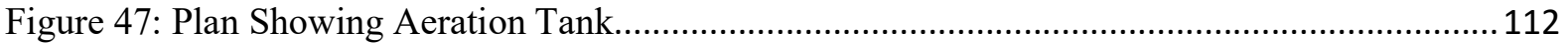

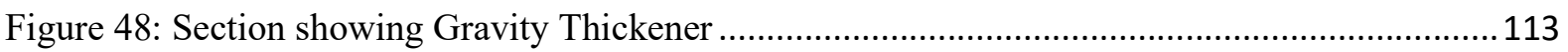

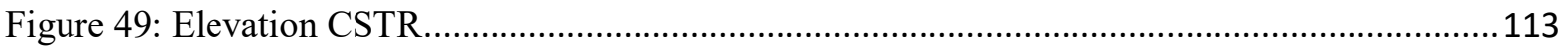

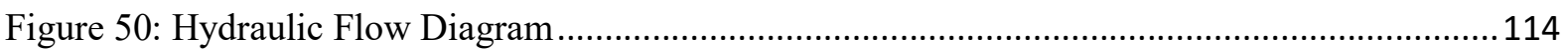




\section{Wastewater Treatment}

\subsection{Introduction}

Wastewater treatment plants are designed to convert raw sewage into less polluted final effluent, and to dispose of the solids removed in the process. It is required to determine the characteristics of the raw sewage and the statutory limits for treatment for effluent, before proceeding with the design of a treatment plant. It is necessary to obtain the approval of a regulatory body before proceeding with construction of any wastewater treatment plant. The regulations of the agency usually establish many of the basic design considerations. Many states have established classifications for various streams within their boundaries. These classifications generally establish "treatment standards" or "effluent standards" which limit the pollution material in the effluent. The "treatment standard" or the "effluent standards" are established taking into account the ability of the receiving waters to assimilate the waste and the uses to which the receiving waters are put. (Ministry of Enviornment -Ontario, 2008) (Kumar, 2011)

Periods of design for treatment plants vary. A normal design period would require treatment units to be designed for population and sewage flows anticipated some 15 to 20 years after completion of construction. Units are designed to be readily expandable as the population increases. (Ministry of Enviornment -Ontario, 2008) (Kumar, 2011)

Water consumption records, where available, are a good basis for determining domestic flow rates. About 80 to $90 \%$ of domestic water consumption may be expected to reach the sewer. In the absence of any better basis, many regulatory agencies accept a rate of 100 gallons per capita per day (gpcd). If commercial sewage flow is quite small in communities, the commercial flow is included as domestic flow. The design average flow rate is the average flow during some maximum significant period such as $4,8,12$, or $16 \mathrm{hr}$, depending on circumstances. (Ministry of Enviornment -Ontario, 2008) (Kumar, 2011)

Determination of important characteristics of sewage is essential to the proper design of treatment works. Where only population data are available, acceptable equivalents for design of treatment works are $0.20 \mathrm{lb}$ of suspended solids (SS) per day per capita or 250 parts per million (ppm) and $0.17 \mathrm{lb}$ of biochemical oxygen demand (BOD) per day per capita or 200 ppm. Sewage treatment processes may be classified as "preliminary”, "primary', "secondary" 
or "advanced" (tertiary). The purpose of preliminary treatment is to remove deleterious materials, which would damage equipment, interfere with the satisfactory operation of a process or equipment, or cause objectionable shore-line conditions. Primary treatment can usually be expected to remove 50 to $60 \%$ suspended solids and 25 to $35 \%$ BOD. Secondary treatment using conventional biological processes may remove up to $90 \%$ of suspended solids and 75 to $90 \%$ BOD. Different biological process units are deployed in secondary treatment. Tertiary or advanced treatment may be expected to remove over $95 \%$ of both BOD and SS in addition to reducing some undesirable chemicals. (Elbeshbishy, 2016)

\subsection{Components of Municipal Water Demand}

Water demand data is used for estimating the wastewater characteristics \& quantity of water. The average amount of municipal water usage in this project is approximately 350 litres per capita per day (Lpcd) (Based on the water consumption for Cambridge in Ontario). Fig 1 shows the major contaminants in the wastewater and Table 1 shows the pollutants and the impacts. This amount includes residential, commercial, light industrial, firefighting, public uses, and water lost or unaccounted for including the irrigation for gardens. The fig 2 shows typical components of the wastewater from community. The Factors affecting water withdrawal rates are:

1) climate,

2) geographic location,

3) size and economic conditions of the community,

4) degree of industrialization,

5) metered water supply,

6) cost of water. Various components of municipal water demand are discussed below. (Elbeshbishy, 2016) 


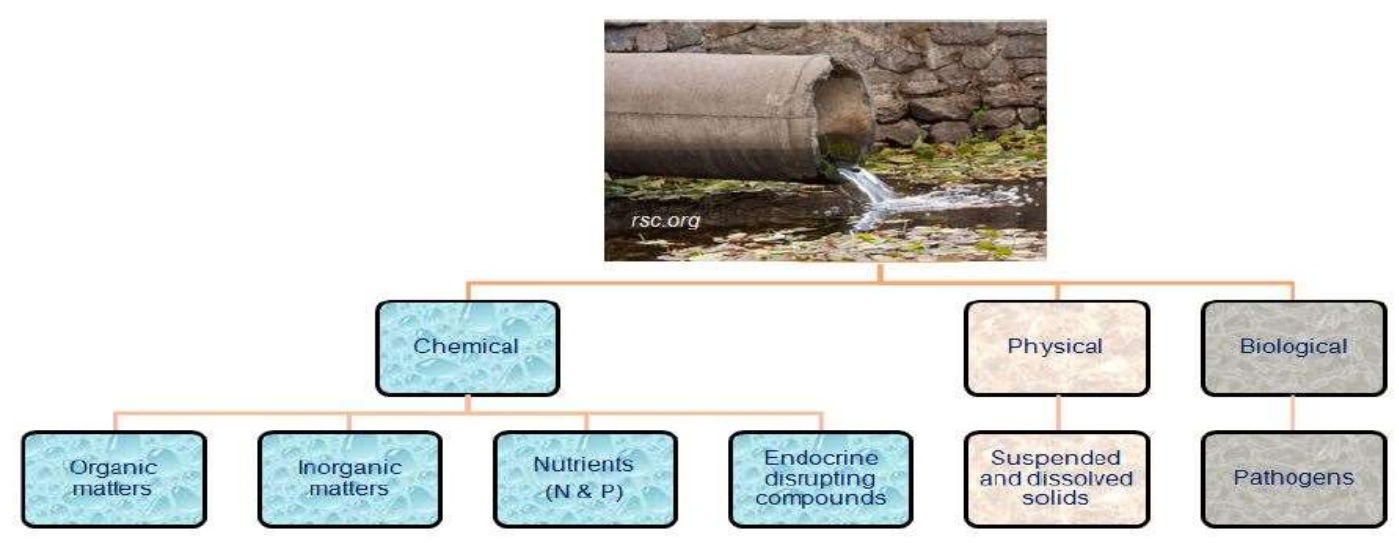

Figure 1: Shows Major Contaminants in Wastewater (Elbeshbishy, 2016)

Table 1: Shows Major Pollutants in Wastewater and Their Impacts (Elbeshbishy, 2016)

\begin{tabular}{|l|l|}
\hline Pollutant & Impact \\
\hline Suspended Solids & Scum layer on water surface, sludge deposits \\
\hline Organic Matter & Dissolved oxygen depletion \\
\hline Nutrients & Eutrophication \\
\hline Pathogens & Transmission of Diseases \\
\hline Heavy Metals & Toxic \\
\hline Endocrine disrupting compounds & Development disorders in both human \& wildlife \\
\hline
\end{tabular}




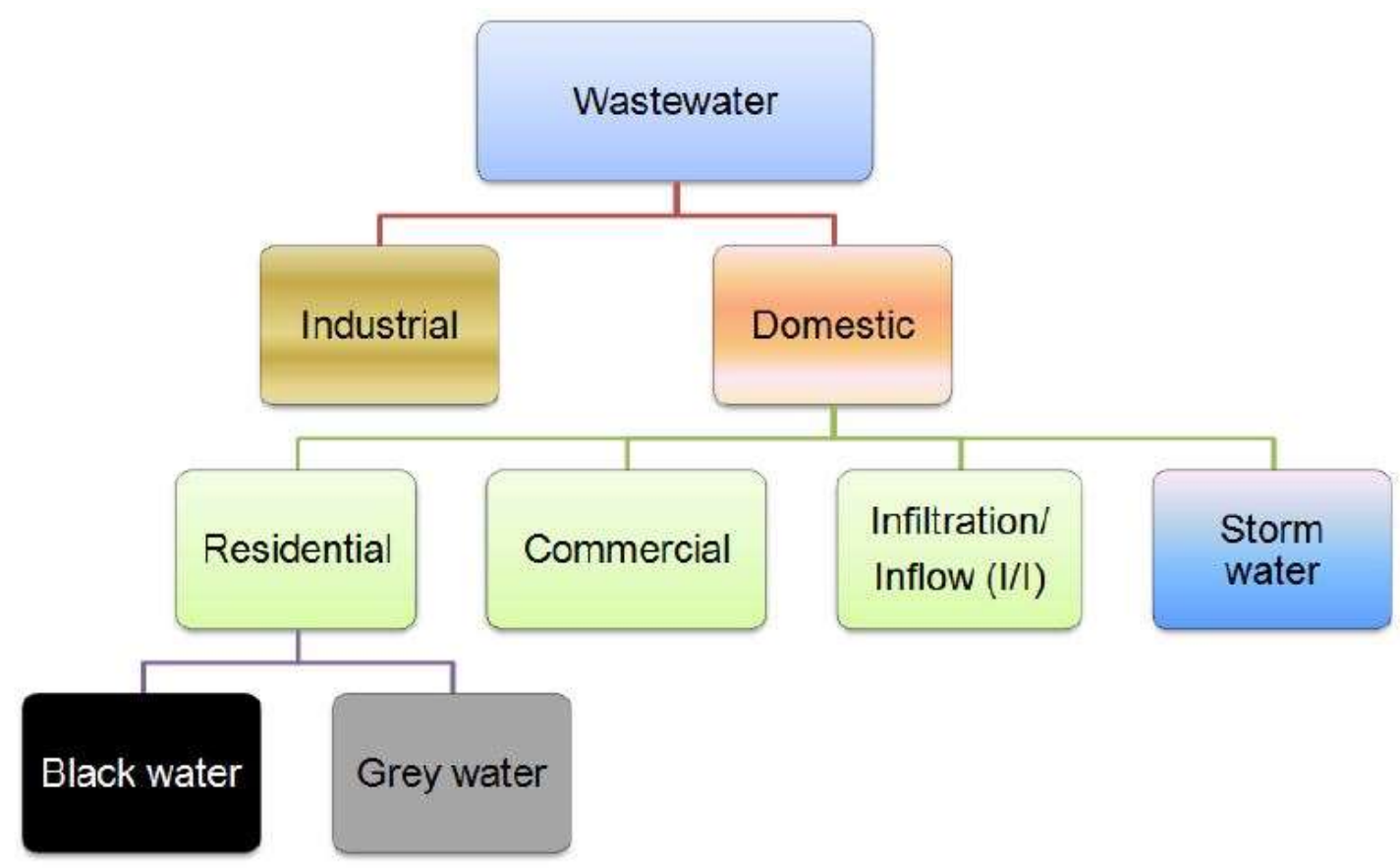

Figure 2: Typical Components of Wastewater Flow from Community (Elbeshbishy, 2016)

\subsubsection{Residential Water Use:}

The residential or domestic water demand is the portion of municipal water supply that is used in homes. It includes toilet flush, cooking, drinking washing, bathing, watering lawn, and other uses.

\subsubsection{Commercial Water Use:}

Commercial establishments include motels, hotels, office building shopping centres, service, stations, airports, and the like.

\subsubsection{Industrial Water Use:}

Water used for industrial processes such as process water, washing, and cooling, and the like.

\subsubsection{Public Water Use:}

Water used in public buildings (city halls, schools, etc.) as well as water used for public services including fire protection, street washing and public park irrigation is considering public water use. 
In a water supply system there is a certain amount of water that is lost or unaccounted for because of meter and pump slippage, leaks in mains, faulty meters. (Elbeshbishy, 2016) (Ministry of Enviornment -Ontario, 2008)

\subsection{Quality of Wastewater:}

Municipal wastewater contains over 99.9 percent water; the remaining substances include suspended and dissolved organic and inorganic materials as well as microorganisms. These materials determine the physical, chemical and biological qualities that are characteristics of residential and industrial wastewaters (Table 2).

\subsubsection{Physical Quality:}

The physical quality of municipal wastewater is generally reported in terms of temperature, colour odour, and turbidity. These physical parameters are shown below: 1) Temperature: the temperature of wastewater is slightly higher than that of water supply. Temperature has effect upon microbial activity, solubility of gases and the viscosity.

2) Colour: fresh wastewater is light grey. Stale wastewater is dark grey or black.

3) Odour: fresh wastewater has soapy or oily odour, which is somewhat disagreeable. Stale wastewater has putrid odours due to hydrogen sulphide, and other products of decomposition.

4) Turbidity: turbidity in wastewater is caused by a wide variety of suspended solidsin general, more polluted wastewater has higher turbidity. 
Table 2: Characteristics of Typical Domestic Wastewater (Elbeshbishy, 2016)

\begin{tabular}{|l|l|}
\hline Contaminant & Concentration Range (mg/L) \\
\hline Total Suspended Solids (TSS) & $100-350$ \\
\hline Volatile Suspended Solids (VSS) & $80-275$ \\
\hline Biochemical Oxygen Demand (BOD 5) & $110-400$ \\
\hline Total Organic Carbon (TOC) & $80-299$ \\
\hline Chemical Oxygen Demand(COD) & $250-1000$ \\
\hline Total Nitrogen & $20-85$ \\
\hline Ammonia Nitrogen & $12-50$ \\
\hline Total Phosphorous & $4-15$ \\
\hline Alkalinity & $50-200$ \\
\hline Grease & $50-150$ \\
\hline Total Coliform & $10^{\wedge} 6-10^{\wedge} 9$ organisms/ $100 \mathrm{ml}$ \\
\hline
\end{tabular}

\subsubsection{Chemical Quality:}

The chemical quality of wastewater is expressed in terms of organic and inorganic constituents. Domestic wastewater generally contains 50 percent organic and 50 percent inorganic matter. A general discussion on organic components, total suspended solids, and inorganic slat of wastewater is given below.

1) Total solids: organic and inorganic, settleable, suspended and dissolved matter. Suspended (TSS), $\mathrm{mg} / \ell$ : portion of organic and inorganic solid that are not dissolved. These solids are removed by coagulation or filtration. Dissolved (Total), mg/ $\ell$ : portion organic and smaller than one mill micron fall in this category.

2) BOD $(5 \mathrm{~d}), \mathrm{mg} / \ell$ : Biochemical oxygen demand $\left(5-\mathrm{d}, 20^{\circ} \mathrm{C}\right)$ it represents the biodegradable portion of organic component. It is a measure of dissolved oxygen required by microorganisms to stabilize the organic matter in 5 day.

3) $\mathrm{COD}, \mathrm{mg} / \ell$ : chemical oxygen demand, it is measure of organic matter and represents the amount of oxygen required to oxidize the organic matter by strong oxidizing chemical (potassium dichromate) under acidic condition.

4) Total nitrogen $(\mathrm{TN}), \mathrm{mg} / \ell$ : total nitrogen include organic nitrogen, ammonia, nitrite, and nitrate.

5) $\mathrm{PH}$ : is indication of acidic or basic nature of wastewater. 


\subsubsection{Microbiological Quality:}

The municipal wastewater contains microorganisms that play an important role in biological waste treatment the principal groups of microorganisms include bacteria, fungi, protozoa, and algae. (Elbeshbishy, 2016) (Ministry of Enviornment -Ontario, 2008)

\subsection{Wastewater Quality Analysis:}

\subsubsection{Carbonaceous Substrates}

Since it is not feasible to track all individual organic compounds in the wastewater, the amount of organics is typically expressed by oxygen that is equivalent to the organic contents in wastewater. Measurement of oxygen demand is used for indirect measurement of the organic matters. The method is based on the oxygen requirement for the oxidation or degradation of the organic matters in wastewater. Typically, two test methods (COD and BOD) are used to determine the oxygen demand of the wastewater.

\subsubsection{BOD (Biochemical Oxygen Demand)}

For BOD measurement, organic compounds are oxidized biologically. During BOD test, aerobic microorganisms degrade organic compounds, while they consume oxygen at the same time (typically for 5 days incubation period at 25oC). The BOD measured in this method is known as five-day BOD (BOD5). Since the microorganisms can partially oxidize organic compounds, measured BOD values are always less than measured COD values for wastewater samples. For example, typical COD/BOD5 for municipal wastewater is $\sim 1.5$. Typical effluent discharge standard for treated municipal wastewater is 5-30 mg BOD5/L. Although BOD analysis is very time consuming and analytical error is relatively high compared to COD test, BOD test is important to evaluate the biodegradability of the wastewater. BOD values can be useful for design and modelling biological treatment processes.

The steps in the laboratory method to measure BOD5 are:

- Measure a portion of wastewater sample into a $300 \mathrm{ml}$ BOD bottle

- Use bacteria (seed) in conditions similar to those of natural waters

- Fill the bottle with aerated dilution water supplemented with nutrients 
- Measure the initial dissolved oxygen (DO)

- Incubate the bottle at $20^{\circ} \mathrm{C}$ for 5 days in the dark

- Measure the final DO

- Calculate BOD5.

Figure 3 shows a typical set-up for BOD measurement. Since the test bottle is sealed, the difference in the initial and final DO values represents the oxygen consumed by microbes in the waste. This difference in DO is an indirect measure of the organic substances in the bottle. The calculation of the BOD is based on a simple mass balance:

$($ Mass of BOD in sample $)=($ Mass of initial DO in bottle at $t=0)-($ Mass of final DO in bottle at $\mathrm{t}=\mathrm{t}$ )

Vsample $($ BOD $)=$ Vbottle $($ DOo $)-\operatorname{Vbottle}($ DOt $)$

$\mathrm{BOD}=(\mathrm{DOo}-\mathrm{DOt}) \times$ Vbottle $/$ Vsample

Where, Vsample is the volume of the wastewater sample used $(\mathrm{mL})$, and Vbottle is the volume of the BOD bottle which is typically $300 \mathrm{~mL}$. The BOD of municipal wastewater may range from 50 to $200 \mathrm{mg} / \mathrm{L}$. Several dilutions are prepared to cover this range. The depletion of dissolved oxygen (DO0-DOt) less than $2 \mathrm{mg} / \mathrm{L}$ or residual dissolved oxygen (DOt) of less than $1 \mathrm{mg} / \mathrm{L}$ may be discarded for accurate BOD5 calculation.

In BOD5 test, 60 to $70 \%$ of the biodegradable organic matter is consumed. Therefore, another term 'ultimate BOD' is used to represent the maximum BOD exerted by the wastewater. 


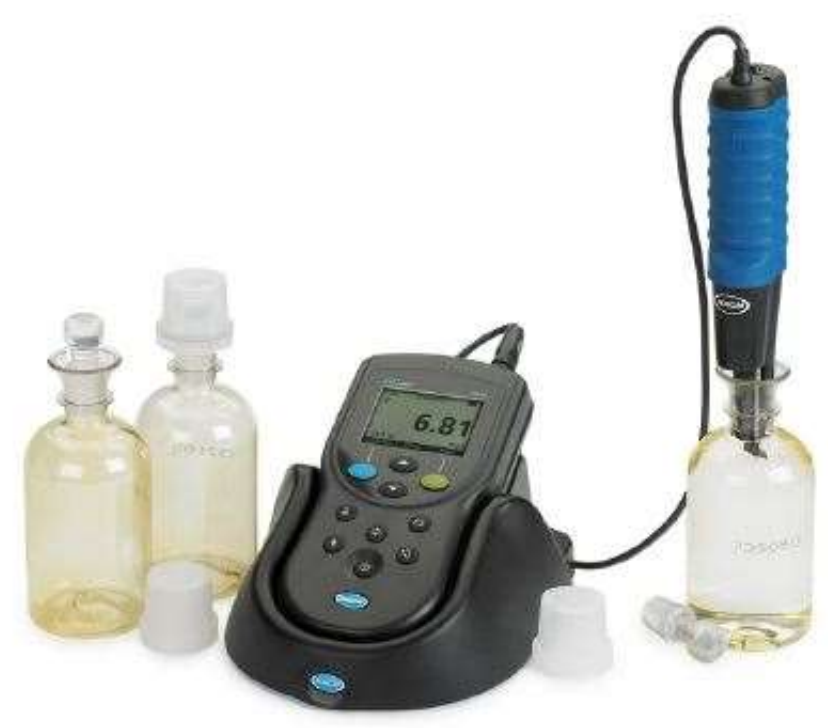

Figure 3: A typical set-up for BOD measurement (www.hach.com)

As shown Figure 4, if we wait for a long time in BOD test, the bacteria will continue consuming the organic material and DO, and the total DO will drop at a point that represents the 'ultimate BOD' (BODu). It is difficult to assign exact time to achieve ultimate BOD, and theoretically it takes infinite time. Typical BODu/BOD5 for municipal wastewater is $\sim 1.5$. Please note that it is possible to develop such correlations for a specific wastewater stream, but such correlations cannot be generalized for use with any other wastewater streams. (Ministry of Enviornment Ontario, 2008) (Elbeshbishy, 2016) (Indian Institute of Technology, India , 2016) 


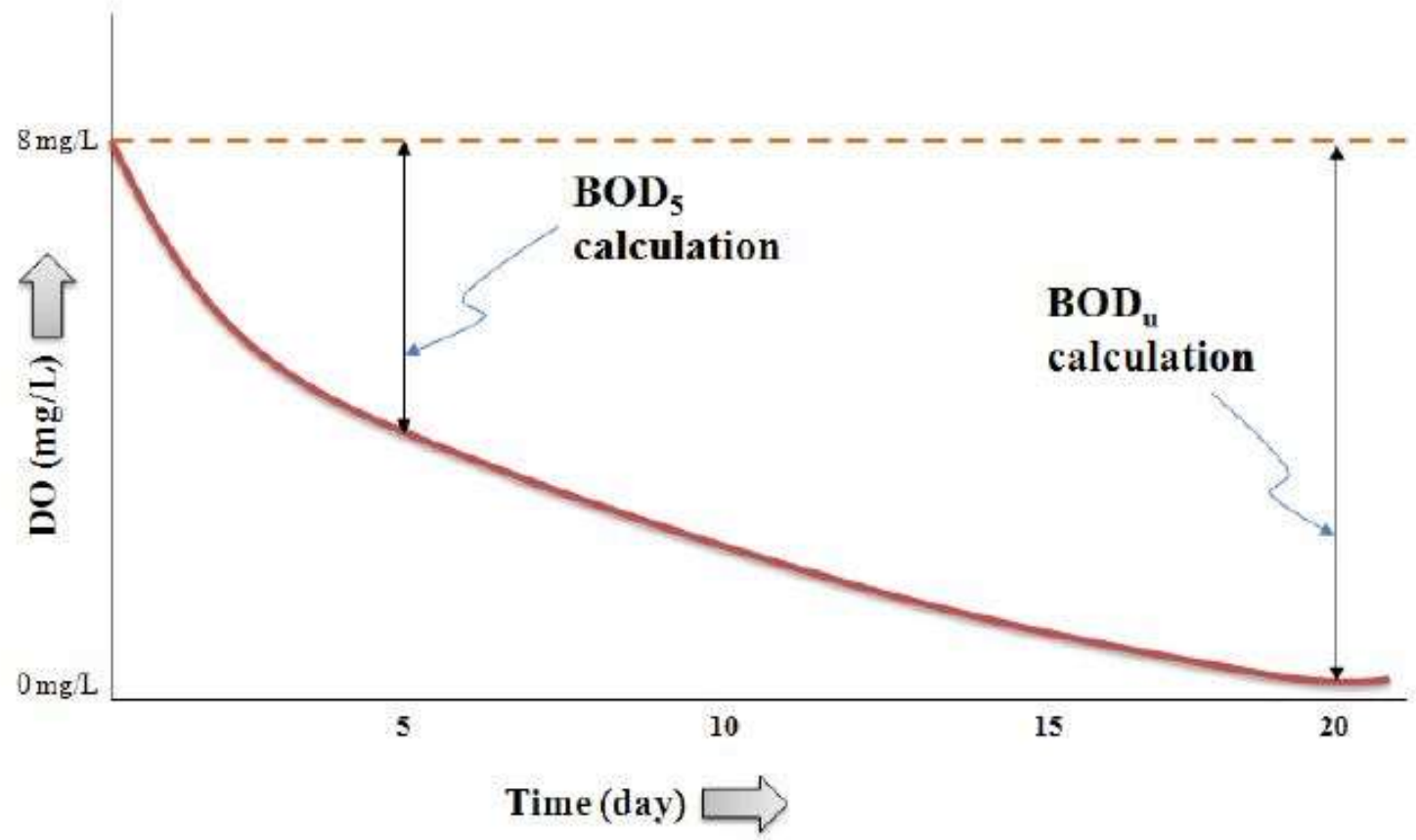

Figure 4: Ultimate BOD Estimation Using Long Term Incubation

Since long incubation and waiting period for BODu result is not desirable, BODu is also estimated using BOD kinetics model or degradation rate of BOD. In a BOD test, the rate at which BOD are degraded by the microbes is assumed to be a first order reaction. Therefore, the rate of BOD utilized is proportional to the amount of available BOD at that time and temperature. Figure 5 shows BOD remaining with incubation time.

Mathematically, we can express this relationship as follows:

$-\frac{d L}{d t}=k L$

Where, $\mathrm{L}$ is amount of BOD remaining to get oxidized by the microbes at time $\mathrm{t}, \mathrm{k}$ is the rate constant.

Integrating,

$L_{t}=L_{o} e^{-k t}$

Where,

Lo $=$ initial BOD of the sample or ultimate BOD $(\mathrm{BODu})$ 
$\mathrm{Lt}=$ remaining $\mathrm{BOD}$ after a given incubation time $(\mathrm{t})$

$\mathrm{t}=$ incubation time

$\mathrm{k}=$ reaction rate constant

BOD removed at time $t, y=L_{o}-L_{t}=L_{o}\left(1-e^{-k t}\right)$

If we measure BOD5, then y can be replaced with BOD5,

$B O D_{5}=B O D_{u}\left(1-e^{-5 \times k}\right)$

If the $\mathrm{k}$ is constant, then the relationship between BOD5 and BODu will be constant.

However, k varies with temperature. For raw domestic wastewater, typical value of $\mathrm{k}$ range from 0.1 to $0.23 \mathrm{~d}-1$ at $20^{\circ} \mathrm{C}$. The temperature effect on biological reaction rates can be expressed using the following Vant's Hoff-Arrhenius equation:

$\frac{k_{2}}{k_{1}}=\theta^{T_{2}-T_{1}}$

where $\mathrm{k}_{1}$ is the reaction rate constant at $\mathrm{T}_{1}{ }^{\circ} \mathrm{C}, \mathrm{k}_{2}$ is the reaction rate constant at $\mathrm{T}_{2}{ }^{\circ} \mathrm{C}, \theta$ is the temperature coefficient. The value of usually $\theta$ varies from 1.03 to 1.25 for biological treatment processes. (Ministry of Enviornment -Ontario, 2008) (Elbeshbishy, 2016) 


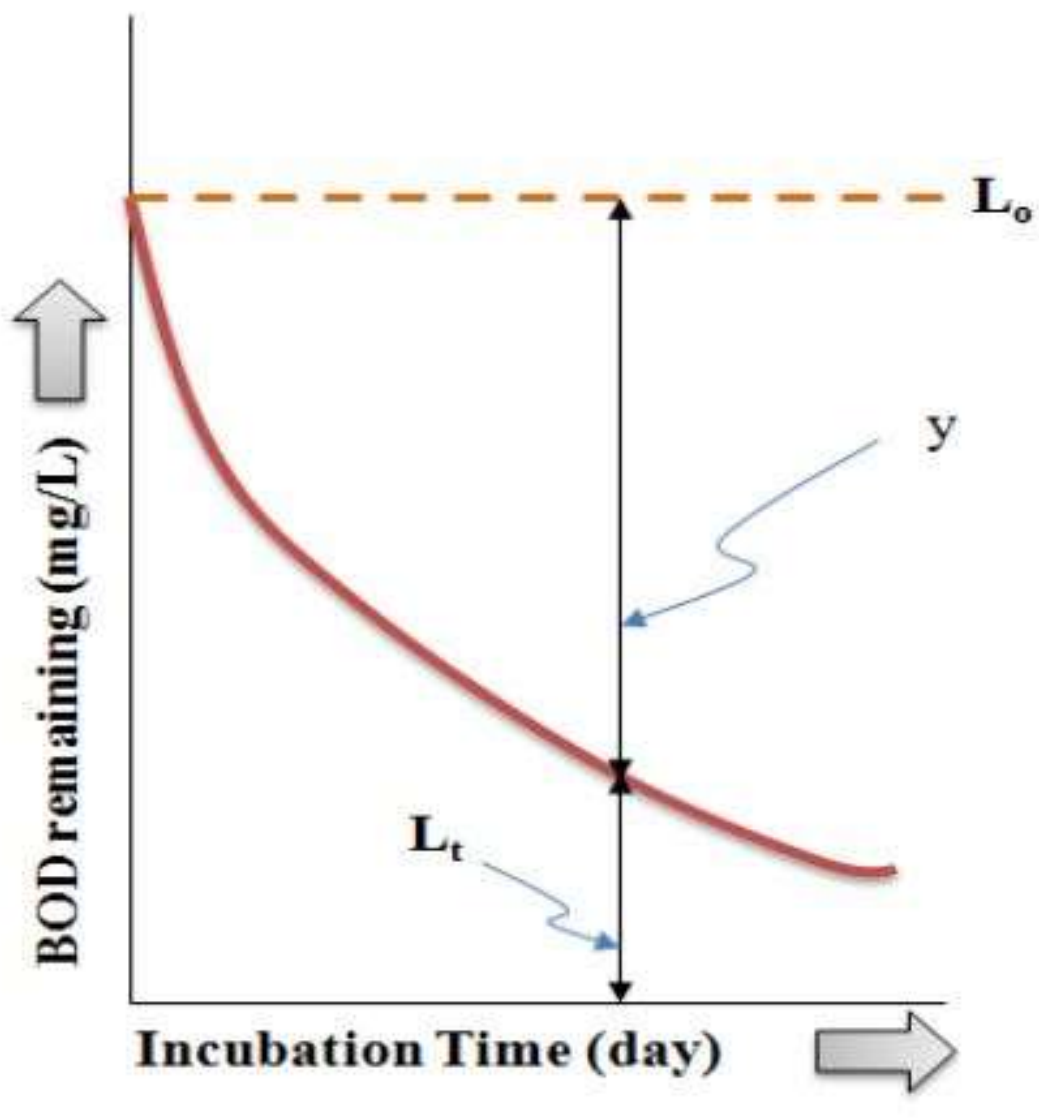

Figure 5: BOD Remaining with Incubation Time. (Elbeshbishy, 2016)

\subsubsection{COD (Chemical Oxygen Demand)}

For COD measurement, all organic compounds are completely oxidized to $\mathrm{CO}_{2}$ under acidic environment using a strong oxidizing agent (e.g., Potassium dichromate, $\mathrm{K}_{2} \mathrm{Cr}_{2} \mathrm{O}_{7}$, and Potassium permanganate, $\mathrm{KMnO}_{4}$ ). Since strong chemical oxidant is used for this analysis, the method is known as chemical oxygen demand. COD test can be conducted within a very short period (1-3 hours), and analytical error is relatively low. Therefore, total COD (TCOD) and soluble COD (SCOD) concentrations are typically measured for rapid monitoring of wastewater characteristics or treatment efficiency. For SCOD measurement, the wastewater sample is typically filtered through $0.45 \mu \mathrm{m}$ membrane filter. The difference between TCOD and SCOD represents the particulate COD (pCOD) fraction in the wastewater. However, measurement of TCOD and SCOD may not be sufficient for simulation and modeling of biological wastewater treatment process. Therefore, a comprehensive analysis of COD fractions may be used for studying advanced wastewater treatment. In comprehensive analysis, 
the total COD in the wastewater is made up of the following fractions with different microbiological properties (Figure 6):

$\mathrm{TCOD}=\mathrm{rbCOD}+\mathrm{sbCOD}+\mathrm{nbsCOD}+\mathrm{nbpCOD}$

Where,

$\mathrm{rbCOD}$ is the readily biodegradable substrate $(\mathrm{mg} / \mathrm{L})$

sbCOD is the slowly biodegradable substrate $(\mathrm{mg} / \mathrm{L})$

nbsCOD non-biodegradable (inert) soluble organic matter (mg/L)

nbpCOD non-biodegradable (inert) particulate organic matter $(\mathrm{mg} / \mathrm{L})$

This comprehensive COD fractionation is used for advanced design and mathematical modelling of wastewater treatment process. (Elbeshbishy, 2016)

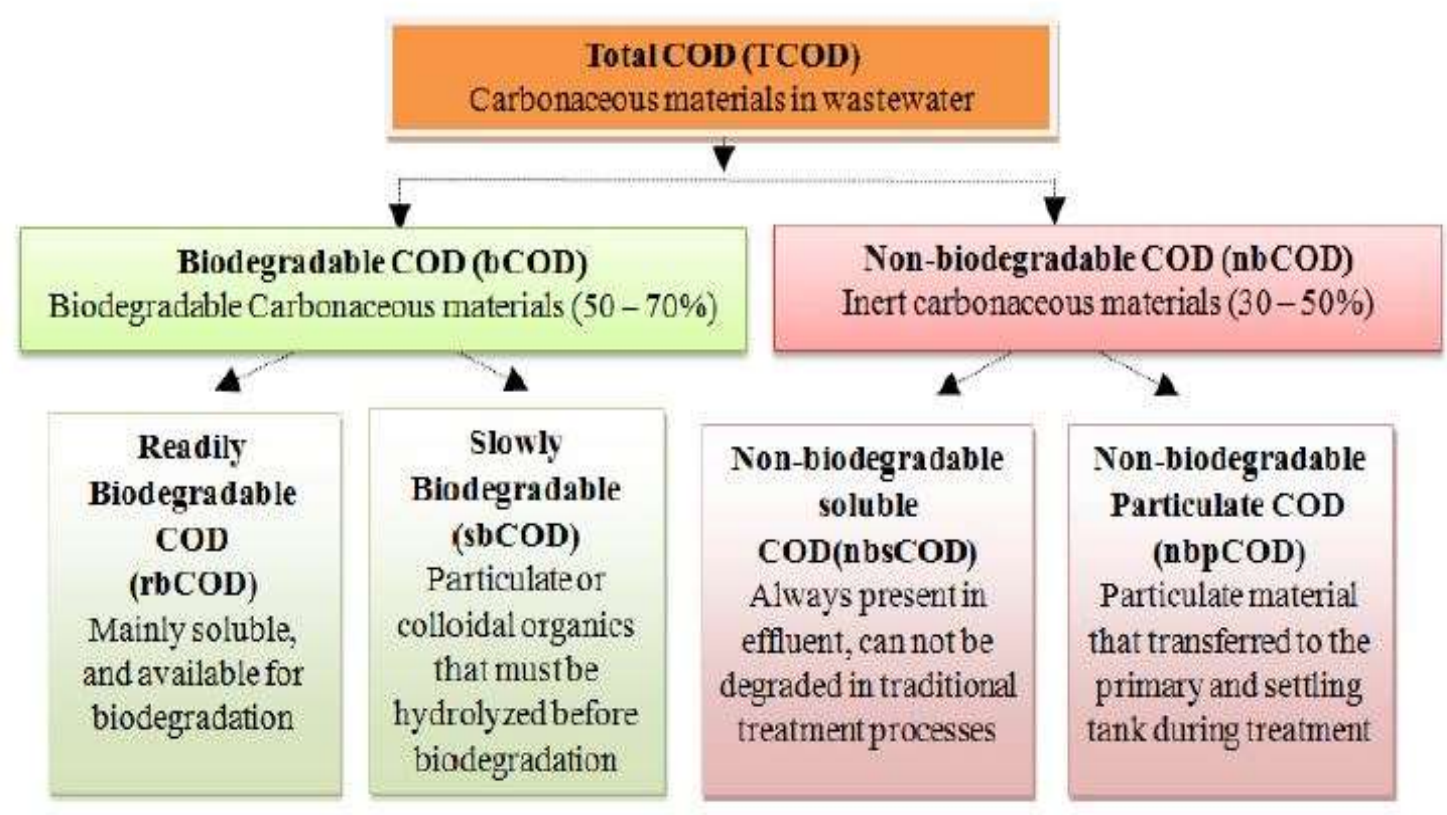

Figure 6: Typical COD Fractionation (Elbeshbishy, 2016) 


\section{Wastewater Collection Systems}

Wastewater collection systems are critical components for wastewater management. Collection systems primarily consist of underground sewer pipes and pumping stations. The time required for the wastewater to reach a WWTP is very important, since it may affect the treatment efficiency. A velocity of at least $0.6-2.4$ meter per second (ideally $0.6 \mathrm{~m} / \mathrm{s}$ ) should be maintained within the wastewater collection system to prevent any settling of solids that may clog underground pipes and cause odors. Therefore, manholes are typically located every 90150 meter to allow maintenance of the sewer. Pumping stations are typically used for low land areas and areas a great distance away from the treatment facility. These pumping stations lift the wastewater to a higher elevation where it can flow again by gravity or may be pumped under pressure to the treatment facility.

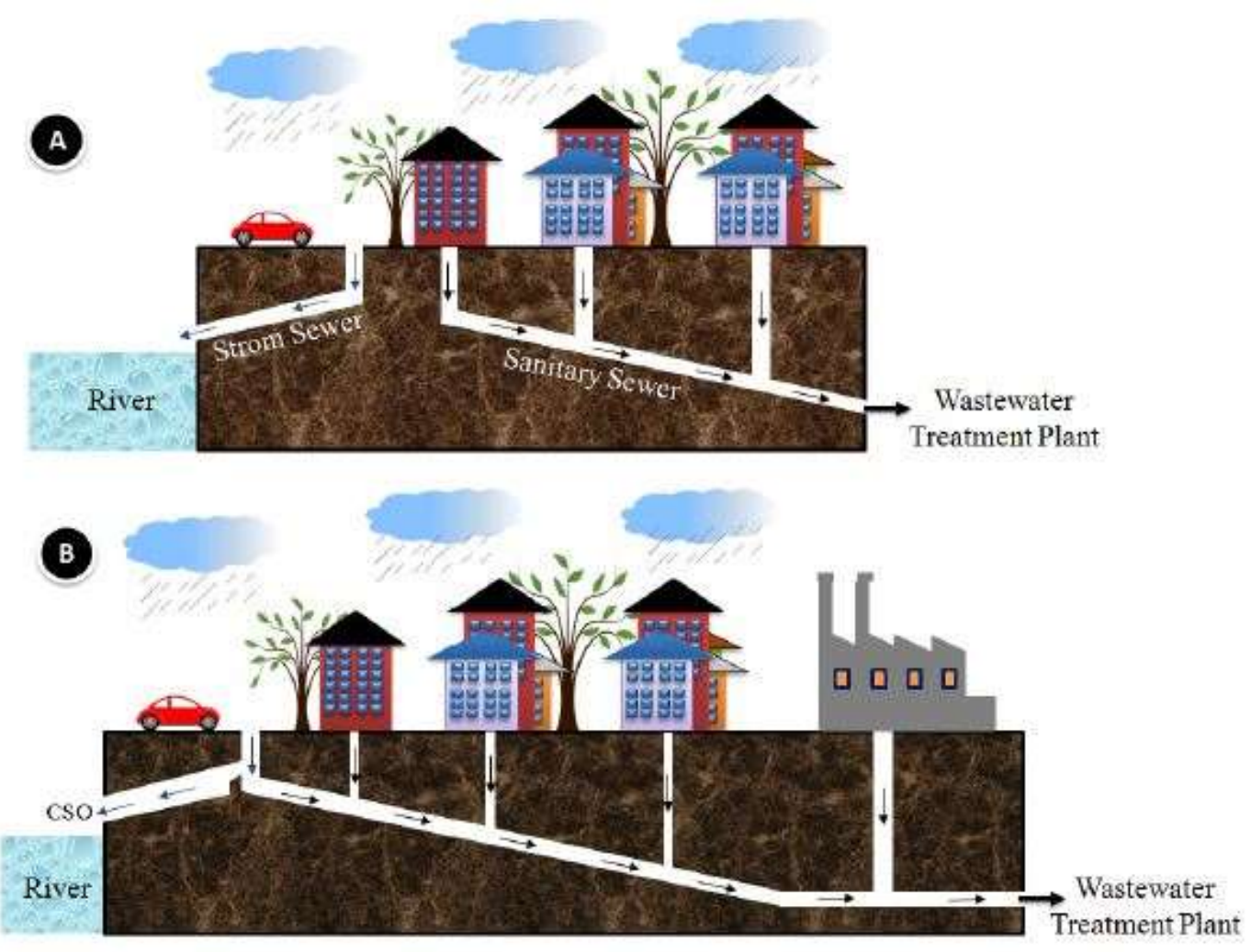

Figure 7: (A) Separate Sewer System, (B) Combined Sewer System (Elbeshbishy, 2016)

Collection system that collects the wastewater from homes, businesses and industries and transports it to a treatment facility is known as sanitary sewer system (Figure 7A). Similar 
system called storm sewer transports rainwater runoff (Figure 7A). Storm water is typically discharged to the water bodies without any treatment. A system transport sanitary sewer, storm runoff, and industrial wastewater is known as combined sewer system (Figure 7B). However, combined sewer systems are very uncommon these days, since they may cause several operational problems. For instance, hydraulic overloading during heavy rainfall or snowmelt may cause complete system failure. Therefore, separate sewer systems are used in most of the developing countries. However, combined sewer systems are designed to overflow occasionally and discharge excess wastewater directly to nearby water bodies (see Figure 3B). These overflows are known as combined sewer overflows (CSOs) which contain untreated domestic and/or industrial wastes along with storm water. Since CSOs can adversely affect aquatic ecosystem and can create aesthetic problems such as odors, high rate treatment process is required for the management of CSOs.

Collection systems represent major capital investments and deteriorate with time and use. The materials that can be used for underground piping must have resistance to damage by the wastewater to minimize leakage. Materials typically used for underground piping are asbestos cement pipe, cast iron pipe, ductile iron pipe, reinforced or non-reinforced concrete pipe, fiberglass reinforced pipe, and high density polyethylene pipe etc. (Elbeshbishy, 2016) 


\section{Treatment Processes}

\subsection{Introduction:}

Physical, chemical or biological treatment methods are combined for wastewater treatment depending on the nature of the pollutants and desired level of removal. Wastewater treatment systems are typically designed as a train of unit operations (physical treatment) and unit processes (chemical/biological treatment) that remove specific classes of contaminants (Figure 8). In general, unit processes are ordered in a way that:

1) Pollutants are removed as efficiently as possible

2) Unit processes are protected from pollutants that will damage them

Modern wastewater treatment process consists of four (four) levels including preliminary, primary, secondary treatment, tertiary or advanced treatment. Preliminary and primary treatments are mainly physical/mechanical (screening and gravity settling), while secondary and tertiary treatments use combination of biological, physical, and chemical treatment process (Figure 9).

Preliminary treatment removes larger inorganic materials and floating particles from raw wastewater that may cause maintenance or operational problems. Typically used unit operations in primary treatment are screen, grit chamber, and dissolved air flotation. During this step, sometimes equalization basin is used for flow balancing or temporary storage of diurnal or wet-weather flow peaks. Primary treatment removes a major portion (50-60\%) of suspended solids from raw wastewater, usually by sedimentation. Sometimes chemical coagulants are added for enhanced primary treatment. The suspended solids settled from the primary clarifier are known as primary sludge (PS) which needs to be treated prior to landfilling. The primary sludge is thickened and sent to the anaerobic digester (AD) for sludge reduction and biogas production by anaerobic microorganisms. Basically, AD is as a multistep biological system where organic materials in the sludge break down by anaerobic microorganisms under an oxygen-free environment. The digested sludge is dewatered and landfilled.

Secondary treatment process removes organic matters and suspended solids. Conventional secondary treatment typically uses basic biological activated sludge (AS) process that consists of an aeration tank followed by a secondary clarifier. In the aeration tank, aerobic microbes convert the dissolved and colloidal organic matters in wastewater to carbon dioxide, water, and 
energy for their growth and reproduction of new cells. The goal of AS systems is to treat wastewaters, which means new synthesized cells should be separated from the treated wastewater. The secondary settling tank separates these microbial cells by gravity settling. The solids (new cells) settled out from the secondary clarifier is known as activated sludge. A portion of the settled biomass is recycled back to the aeration tank (known as recycled activated sludge or RAS), while another portion of the sludges are taken out from the system (known as waste activated sludge or WAS). The WAS is thickened and sent to the AD along with PS. Other unit processes that can be used for secondary treatment are aerated lagoon, anaerobic lagoon, rotating biological contractor (RBC), trickling filter, up-flow anaerobic sludge blanket (UASB). These processes are typically used for small scale WWTP. The supernatant liquid from the secondary settling tank may contain a significant amount of nutrients (nitrogen and phosphorous). Nitrogen can be biologically removed via oxidation of ammonia to nitrate (known as nitrification process) followed by nitrate reduction to nitrogen $\left(\mathrm{N}_{2}\right)$ gas (denitrification process). Phosphorous is removed by another biological process known as enhanced biological phosphorous removal (EBPR). In EBPR process, specific microbes, known as polyphosphate-accumulating organisms (PAOs) accumulate large quantities phosphate as polyphosphate within their cell bodies. Thus, phosphorous can be removed from the wastewater. When the cells are enriched with polyphosphate, the biomass is then separated from the treated wastewater. Chemical treatment using ferric chloride or alum can be also used for phosphorous removal. Before discharge to the water bodies, disinfectants are added for pathogen removal from treated wastewater. However, sometimes granular media filtration, ion exchange, reverses osmosis, activated carbon adsorption, and air stripping is used to remove residual suspended solids, volatile organic compounds, specific ions, toxic compounds to achieve desired level of treatment. (Elbeshbishy, 2016) (Federation of Canadian Municipalities and National Research Council, 2003) 


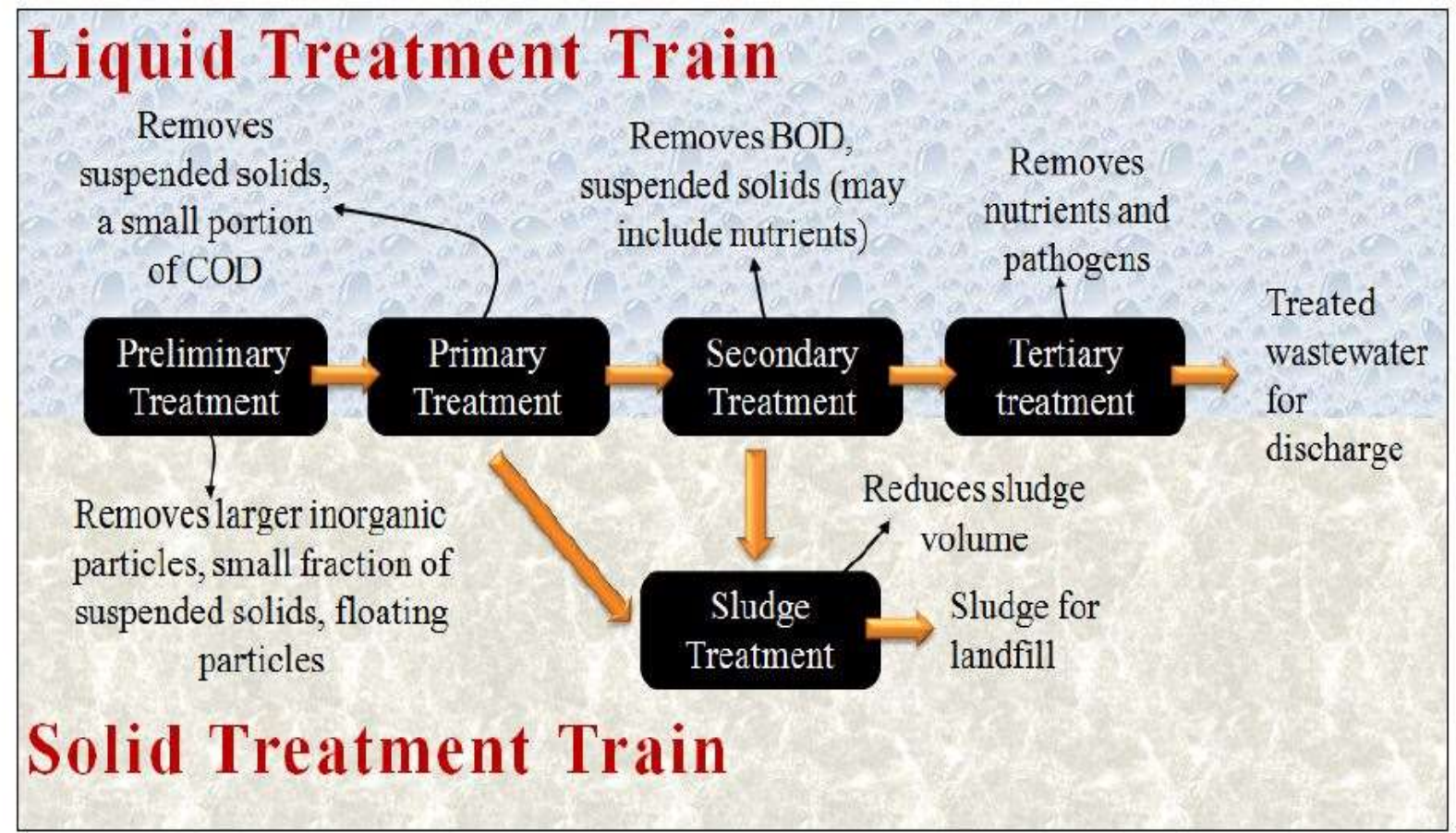

Figure 8: Typical Steps in Wastewater Treatment (Elbeshbishy, 2016)

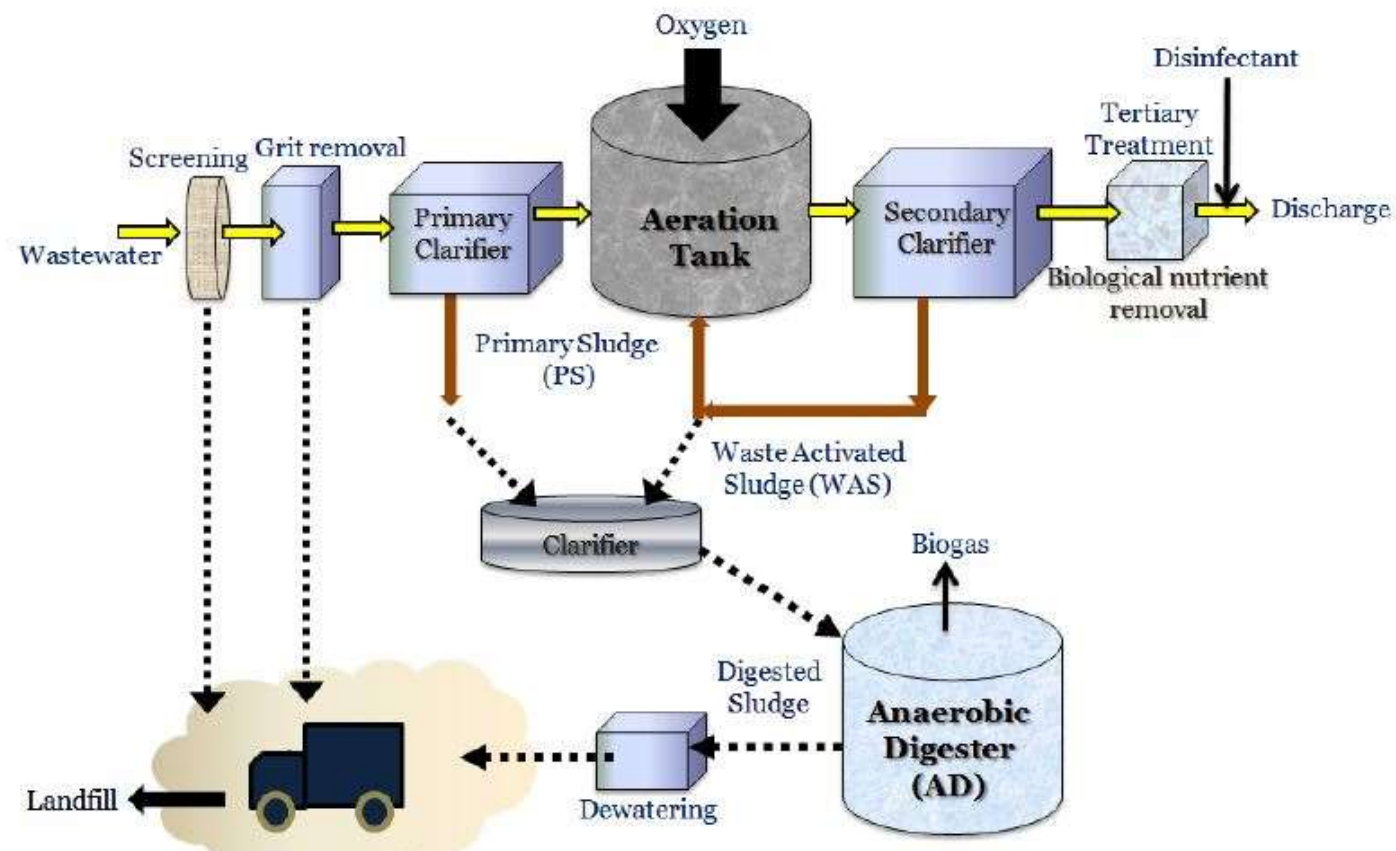

Figure 9: Typical Municipal Wastewater Treatment Process (Elbeshbishy, 2016) 


\subsection{Preliminary Treatment Units:}

It includes unit operations such as:

\subsubsection{Screens:}

The general purpose of screens is to remove large objects such as rags, paper, plastics, metals, and the like these objects, if not removed may damage the pumping and sludge- removal equipment, including choking the pipes and pumps and hampering the growth of the microbes in the biological units.

The main two types of screens are coarse and fine screens. (Elbeshbishy, 2016) (Federation of Canadian Municipalities and National Research Council, 2003)

\section{Coarse Screens:}

Coarse screens remove large solids, rags, and debris from wastewater, and typically have openings of $6 \mathrm{~mm}(0.25 \mathrm{in})$ or larger. The most widely used coarse screen in wastewater industry is bar screens (Figure $10 \mathrm{~A} \& \mathrm{~B}$ ). Based on the cleaning operation bar screens are classified as manually cleaned screens or mechanically cleaned screens. The bar spacing for mechanically cleaned screen is in the range of $1.5-4 \mathrm{~cm}$, while the bar spacing for manually cleaned bar screens is in the range of $2-5 \mathrm{~cm}$. Manually cleaned screens are typically mounted at an angle of 45-70 degree from horizontal to increase cleaning surfaces, making cleaning easier, and prevent excessive head loss by clogging. Mechanically cleaned screens are mounted at an angle of 70-90 degree from horizontal. For mechanically cleaned screens, at least two units should be installed so that one unit may be taken out of service for maintenance. (Elbeshbishy, 2016)

- For wastewater flow rates $>1000 \mathrm{~m} 3 / \mathrm{d}$, mechanically cleaned screens are preferred 

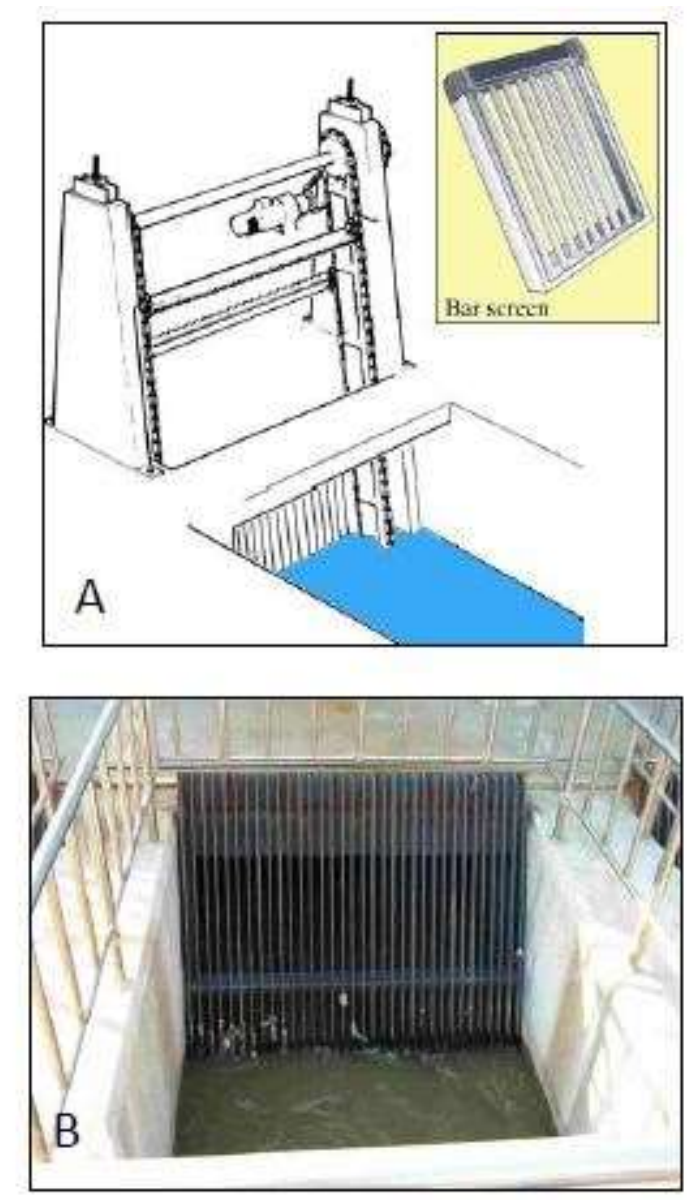

Figure 10: (A) Schematic of a Typical bar Screen used in wastewater treatment plant (source water.me.vccs.edu) (B) photograph of a bar screen (http://www.infobarscreens.com/bar-screen.jpg)

\section{Fine Screens:}

Fine screens are typically used to remove material that may create operation and maintenance problems in downstream processes, particularly in wastewater treatment plants that lack primary treatment. Typical opening sizes for fine screens are less than $6 \mathrm{~mm}$. Very fine screens with openings of 0.2 to $1.5 \mathrm{~mm}$ placed after coarse screens can reduce suspended solids to levels near those achieved by primary clarification. However, capital cost and maintenance for fine screens is much higher than coarse screens. Fine screens are typically used to remove material that may create operation and maintenance problems in downstream processes, particularly in wastewater treatment plants that lack primary treatment. Typical opening sizes for fine screens are less than $6 \mathrm{~mm}$. Very fine screens with openings of 0.2 to $1.5 \mathrm{~mm}$ placed after coarse screens can reduce suspended solids to levels near those achieved by primary clarification. However, capital cost and maintenance for fine screens is much higher than 
course screens. Figure 3 shows a schematic of a commercial fine screen. Fine screens may remove TSS in wastewater ranging from 10 to $80 \%$ (55\% average). (Elbeshbishy, 2016)

Figure 11 shows a schematic of a commercial fine screen.

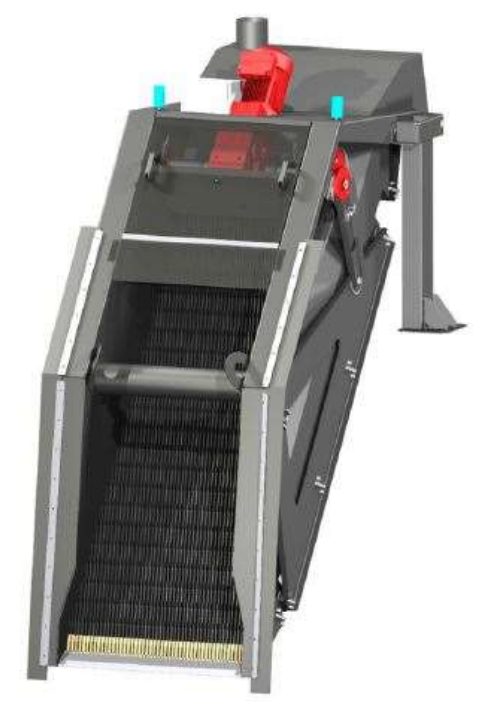

Figure 11: Fine Screen (Elbeshbishy, 2016)

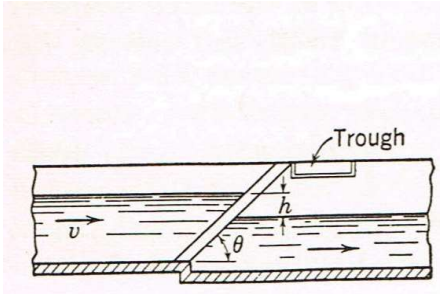

(a)

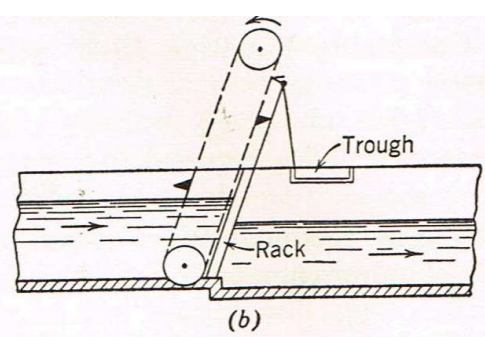

(b)

\section{Figure 12: Shows Manual \& Mechanized Screen Cleaning (Indian Institute of Technology, India , 2016)}

\subsubsection{Aerated Grit Chambers:}

Minute pieces of mineral matter like sand, and gravel, and materials that are not of mineral origin like coffee grounds, seeds, and similar material constitute grit. Grit in sewage has two characteristics: (1) They are non-putrescible and (2) they have subsiding velocities substantially greater than those of organic putrescible solids.

Grit chambers are located downstream of screen chambers. The purpose of a grit chamber is three fold: (1) the protection of moving mechanical equipment from abrasion and accompanying abnormal wear, (2) the reduction of pipe clogging caused 
by deposition of grit particles or heavy sludge in pipes and channels, particularly at changes in direction of conduits, and (3) reduction of frequency of digester and settling tank cleaning required as a result of excessive accumulation of grit in these units. Fig 13 shows section of aerated grit chamber. (Elbeshbishy, 2016)

\section{Horizontal Flow Grit Chamber:}

In the horizontal flow type, the flow passes through the chamber in a horizontal direction. A constant velocity of flow through the grit chamber must be maintained at $0.9 \mathrm{~m} / \mathrm{sec}$ for all depths of flow in order to prevent settling of organic solids. This is accompanied by means of providing a sutro weir. (Ministry of Enviornment -Ontario, 2008) (Elbeshbishy, 2016)

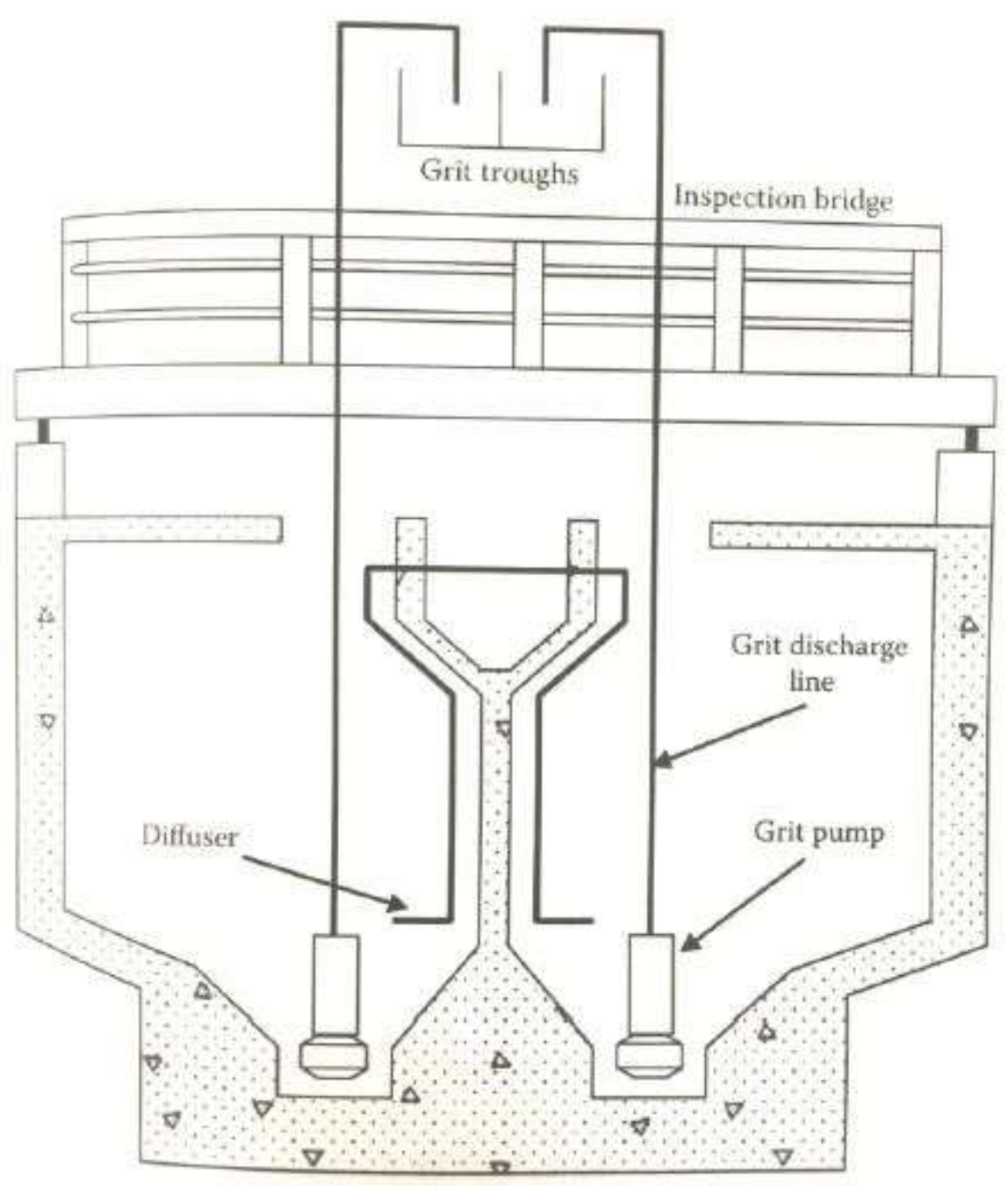

Figure 13: Aerated Grit Chamber (Elbeshbishy, 2016) 


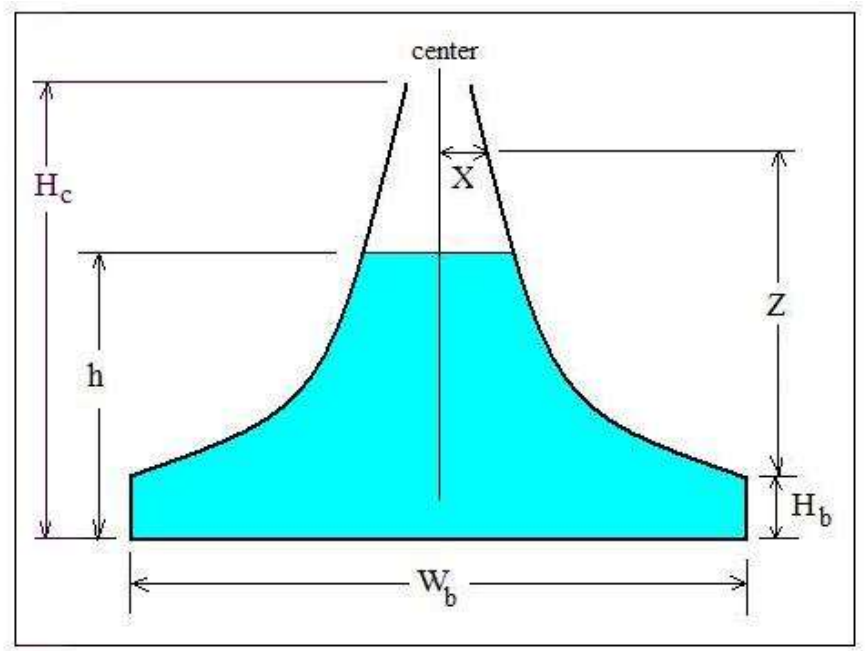

Figure 14: Sutro Weir (Ministry of Enviornment -Ontario, 2008)

\section{Aerated Grit Chamber:}

The aerated type consists of a spiral-flow aeration tank, the spiral velocity being controlled by the dimensions and the quantity of air supplied to the unit. The detention provided is 3 minutes at the maximum flow rate.

The grit solids are raked by a rotating mechanism to a sump at the side of the tank, from which they are moved by a reciprocating rake mechanism. The quantities of grit vary from one location to another depending on the type of sewerage system, the characteristics of the drainage area, the condition of the sewers, the frequency of street sanding, the type of industrial wastes, the number of garbage grinders served, and the proximity and use of sandy bathing beaches. There is a wide range in the quantity of grit varying from $1 / 3 \mathrm{ft}^{3}$ to $24 \mathrm{ft}^{3}$ per million gallon of sewage treated. Because of the wide variation, a factor of safety must be used in calculations concerning the actual storage, handling, or disposal of the grit.

Common method of grit disposal is as fill, covered if necessary to prevent objectionable conditions. Grit also is incinerated with sludge. In coastal cities grit and screenings are barged to sea and dumped. Generally, the grit must be washed before removal.

\subsection{Flow Equalization}

The wastewater to be treated in the WWTP has a lot of variations in flow rates. Since a WWTP is typically designed for a certain flow rate, treatment performance can't sustain during large daily or seasonal variations in flow rates. In-line and side-line flow equalization is a method to overcome such problems related to fluctuations in flow rates (Figure 15). Flow equalisation basins store excess water for later treatment. Flow 
equalisation basin is located after most of the preliminary treatment units such as screening and grit removal but before primary sedimentation.

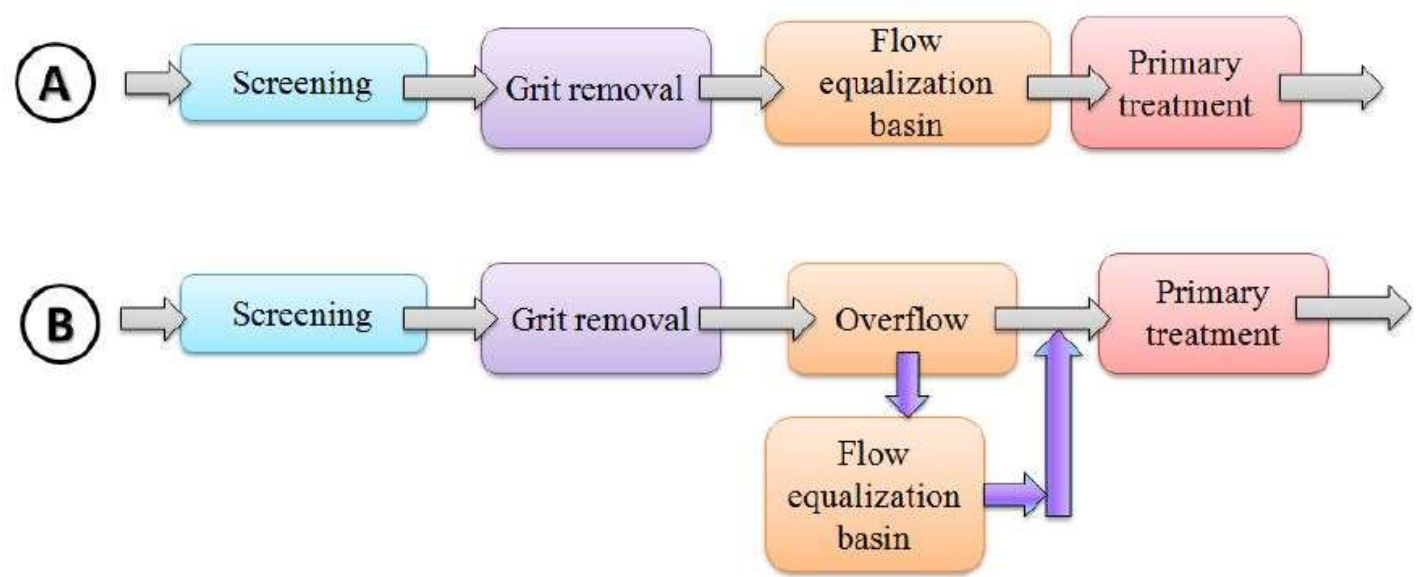

Figure 15: Types of Flow equalization (A) inline, (B) Side-line (Elbeshbishy, 2016)

- Flow equalization $\rightarrow$ a method of damping the variation in flow rates $\rightarrow$ NOT a treatment

\section{Design of Equalization Basin:}

The principal design parameter of flow equalization basin is size, and typically designed as completely mixed basins. Flow equalisation basins are typically designed by examining cumulative inflow over one day. Figure 16 shows two typical inflow patterns. The straight line drawn from origin to the end point of the diagram shows the average daily flow rate. (Elbeshbishy, 2016)

For Flow Pattern A, a line parallel to the average daily flow rate is drawn at the low point of tangency to the cumulative inflow curve. The vertical distance from the point of tangency to the straight line representing the average flow rate represents the required volume for equalization basin. At lower point of tangency, the storage basin would be empty. Beyond this point, the basin will be beginning to fill because the slope of the cumulative inflow diagram is higher than the average daily flow rate. (Elbeshbishy, 2016)

- For Flow Pattern B, required volume for equalization basin can be determined by drawing lines which is tangent at low and high points. The required volume is vertical 
distance between the two lines. The basin will be completely filled at the upper point of tangency. (Elbeshbishy, 2016)

- In practice, the volume of basin will be $10-20 \%$ larger than the theoretically determined volume to accommodate sudden increase in flow.

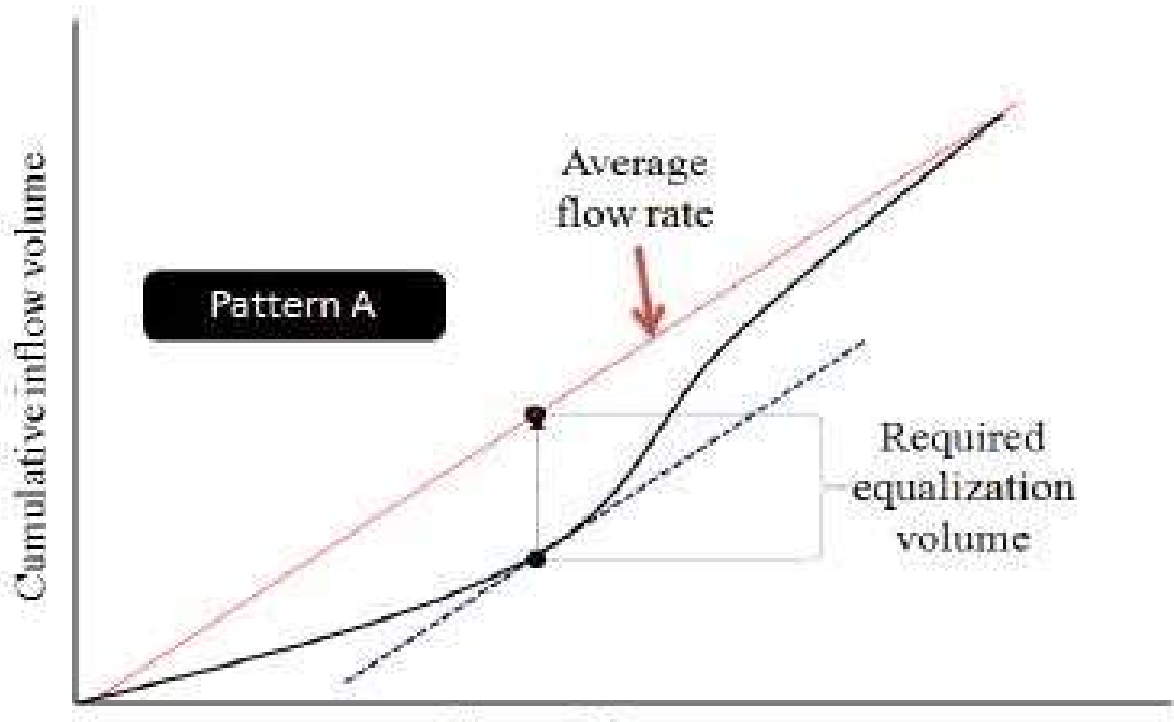

Time of day

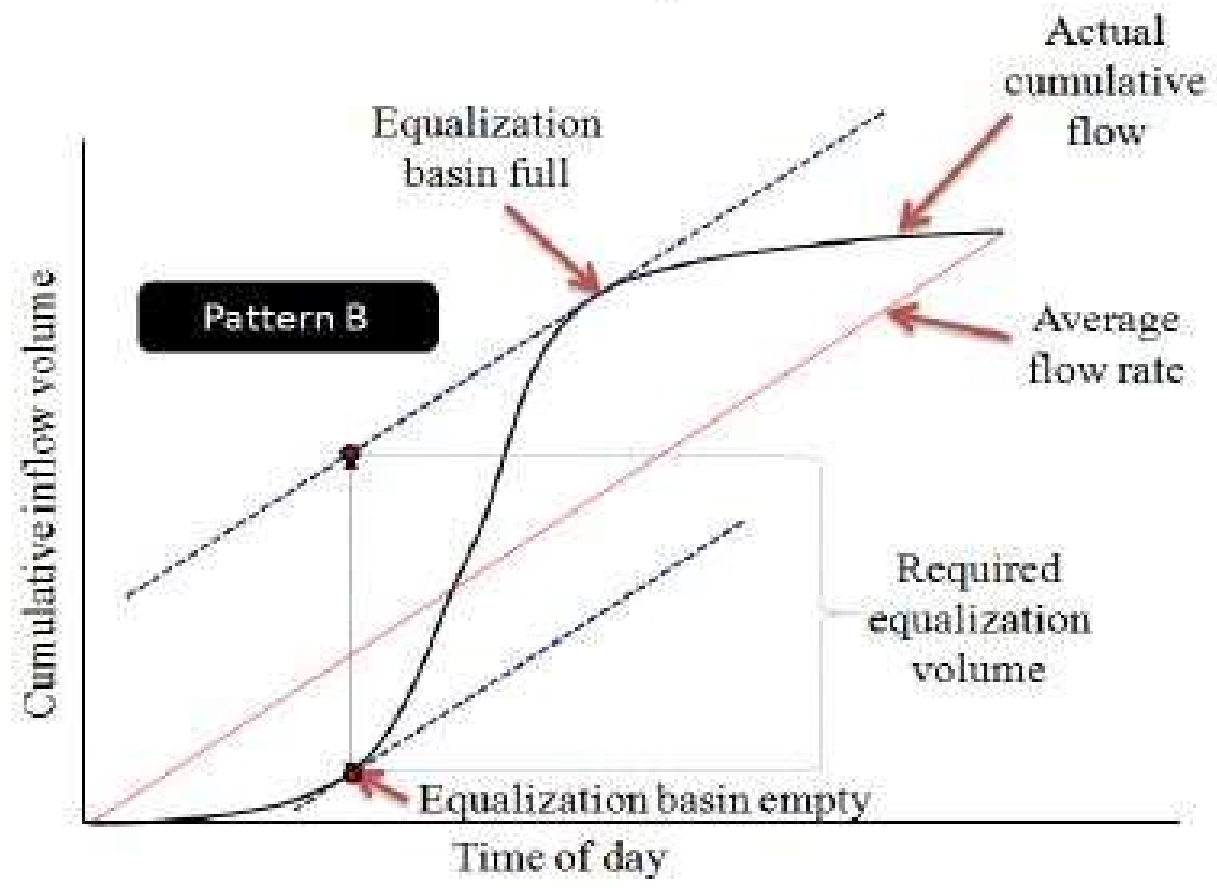

Figure 16: Design of Flow Equalization Basin (Elbeshbishy, 2016) 


\subsection{Primary Treatment}

Primary treatment consists of settling the sewage in a sedimentation tank. Whenever a liquid containing solids in suspension is placed in a relatively quiescent state, those solids having a higher specific gravity than the liquid will tend to settle, and those with lower specific gravity will tend to rise. These principles are utilized in the design of sedimentation tanks. The objective of treatment by sedimentation is to reduce the suspended solids content by removing readily settleable solids and floating material. (Elbeshbishy, 2016) (Federation of Canadian Municipalities and National Research Council, 2003)

Efficiently designed and operated primary sedimentation tanks should remove from 50 to $65 \%$ of SS and 25 to $40 \%$ of BOD. Sedimentation tanks are normally designed on the basis of a surface-loading rate at the average rate of flow, expressed as gallons/day $/ \mathrm{ft}^{2}$ of horizontal area. The effect of surface-loading rate and detention time on SS removal varies widely depending on the character of the sewage, proportion of settleable solids, concentration of solids, and other factors. When the area of the tank has been established, the detention period in the tank is governed by water depth. (Elbeshbishy, 2016) (Ministry of Enviornment -Ontario, 2008)

Surface settling rates not followed by secondary treatment shall not exceed 600 gallons per day per square foot $\left(\mathrm{gpd} / \mathrm{ft}^{2}\right)$ for design flow of $1 \mathrm{mgd}$ or less. Higher rates may be permitted for larger plants. Normally, primary detention tanks are designed to provide 90 to $150 \mathrm{~min}$ of detention based on the average rate of sewage flow. Weir loadings should not exceed 10,000 gallons/linear ft/day for plants designed for average flows of 1 MGD or less. For plants designed for higher flows, the weir loading rate can be increased up to a maximum of 15,000 gallons/linear $\mathrm{ft} /$ day. Weir rates have been found to have less effect on efficiencies of removal than over flow rates. A minimum water depth of $7 \mathrm{ft}$ is recommended. (Elbeshbishy, 2016) (Ministry of Enviornment -Ontario, 2008)

Tank type, size and shape - Almost all sedimentation tanks are designed as rectangular or circular tanks with mechanical cleaning mechanism. The selection of the shape is governed by the size of the installation, by rules and regulations of permitting authorities, by local site conditions and the estimate of cost. Two or more 
tanks should be provided in order that the process may remain in operation while one tank is out of service for maintenance and repair work.

Rectangular tanks - The length of rectangular tanks is restricted to $300 \mathrm{ft}$. Tank widths may not be more than $80 \mathrm{ft}$, but it should be divided in to 4 bays so that the cleaning mechanism can be installed in a 20 -foot width bay.

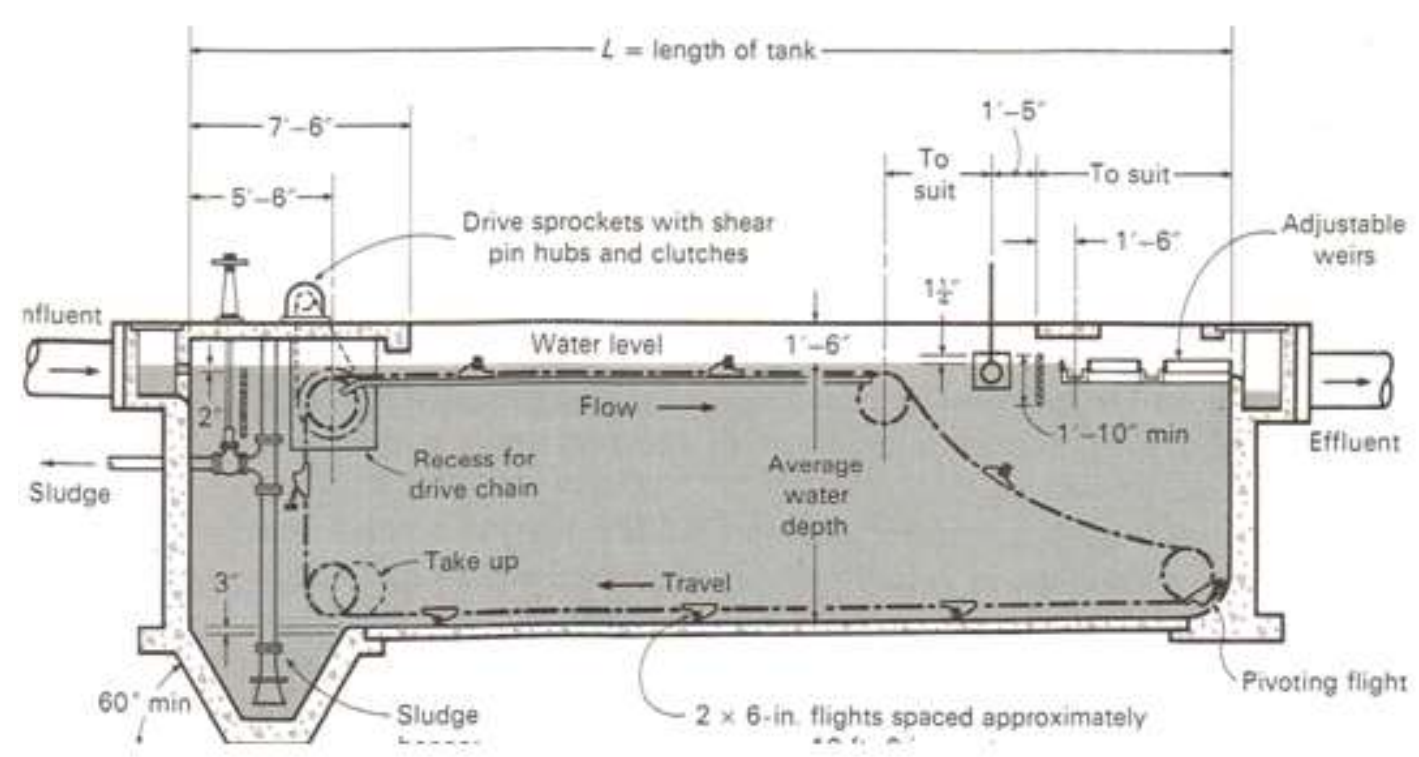

Figure 17: Rectangular Sedimentation Tank (Ministry of Enviornment -Ontario, 2008)

Circular tanks - The diameter of round tanks varies from 10 to $180 \mathrm{ft}$ with no single factor influencing the selection other than the size of the plant. The side wall depth varies from 7 to $14 \mathrm{ft}$. Floors are deepest at the center and slope radially upwards to the tank walls at a rate of 1 in per ft. The slope facilitates sludge withdrawal and drainage of the tank.

In one type of circular tanks, the sewage is carried to the center of the tank in a pipe suspended from a bridge or encased in concrete beneath the tank floor. At the center of the tank, sewage enters a circular well designed to distribute the flow equally in all directions. The removal mechanism moves continuously at a peripheral speed of 5 to $8 \mathrm{ft} / \mathrm{min}$ and may have two or four arms equipped with scrapers. The arms also support blades for scum removal. In the second type, a suspended circular aluminium baffle at a short distance from the tank wall forms an 
annular space into which the sewage is distributed in a tangential direction. The sewage flows spirally around the tank and underneath the baffle, the clarified liquid being skimmed off over weirs on both sides of a centrally located weir trough. Grease and scum are confined to the surface of the annular space. Intervals of pumping the sludge vary from once in 30 min to once in 12 hours depending upon the volume to be pumped and the plant operating schedules.

\section{Operation of Primary Sedimentation}

For continuous operation, minimum two primary settling tanks are provided. In practice, primary settling tank can be circular or rectangular (Figure 17, 18 and 19). The selection of type of clarifier depends on:

- Preference of regulatory authorities

- Size of installation

- Local site condition

\section{Rectangular Clarifiers vs. Circular Clarifiers}

Advantages of rectangular design over circular design:

- Occupy less space when multiple units used

- Provide longer travel distance for settling to occur

- Less short circuiting of liquids

Advantages of rectangular design over circular design:

- Possible dead corners

- Sensitive to flow surges

- Higher maintenance costs of chains \& flights 

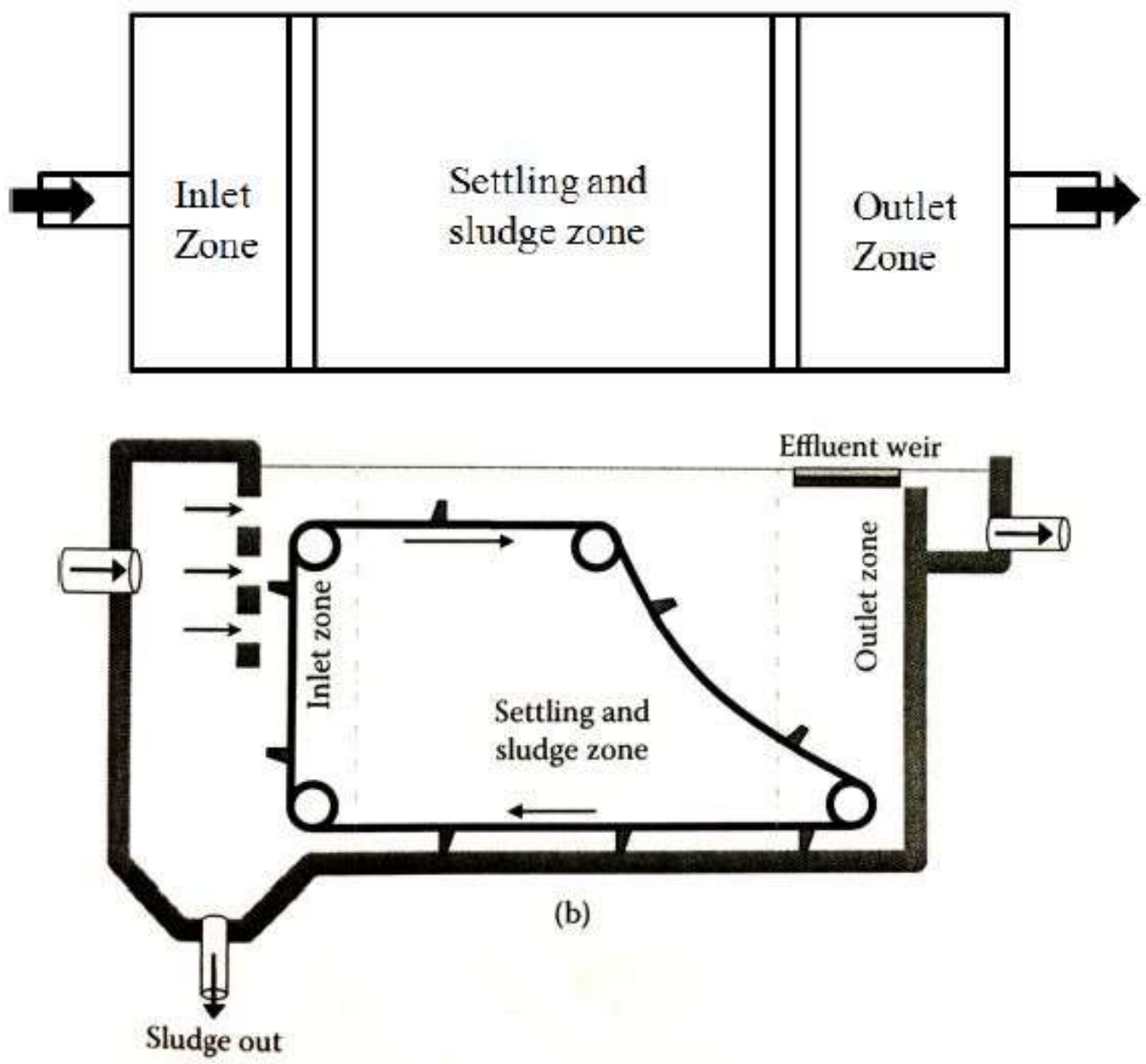

Figure 18: Rectangular Clarifier with Zones (Elbeshbishy, 2016)

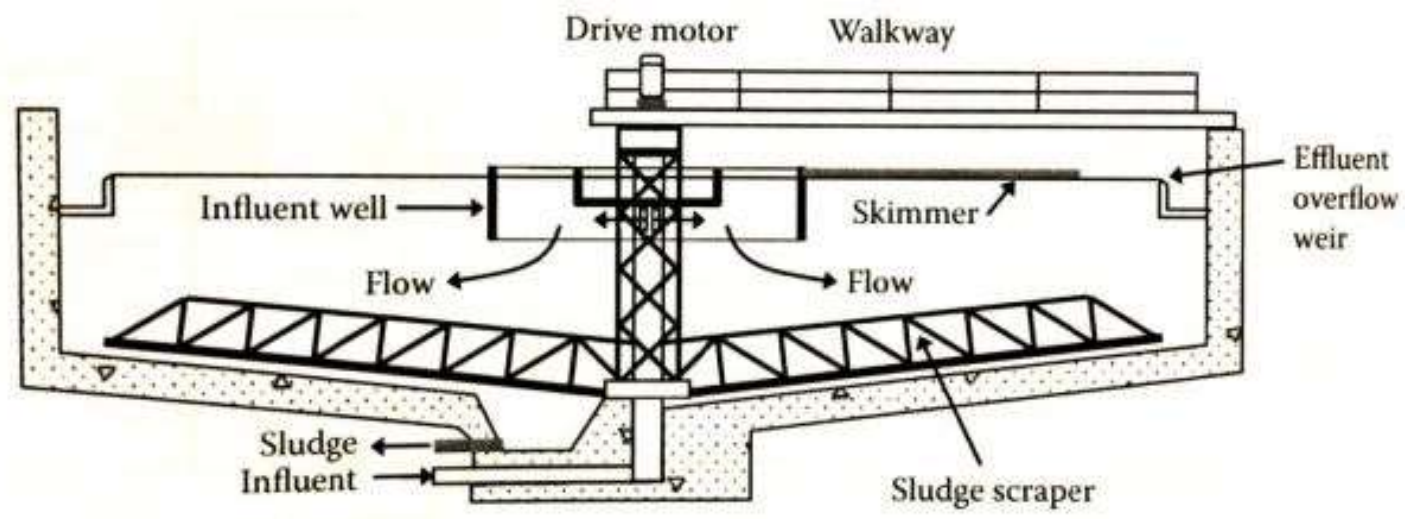

Figure 19: Circular Clarifier (Source Riffat, 2012) 


\subsection{Biological Treatment (Secondary Treatment)}

The idea of secondary treatment is to get rid of the soluble organics that is not possible to be treated in primary treatment process. These dissolved and suspended organic materials are decayed by the microorganisms usually Hetrotrophs in aerobic environment to more stable organic matter and subsequently are removed as sludge from the wastewater.

The secondary treatment can eliminate more than 85 percent of the BOD (5 d) and suspended solids, it does not eliminate the significant amount of nitrogen, phosphor heavy metals, no degradable organics, bacteria and viruses. (Elbeshbishy, 2016) (Indian Institute of Technology, India , 2016)

\subsubsection{Activated Sludge Process}

The most common suspended growth process used for municipal wastewater treatment is the activated sludge process as shown in figure 20:

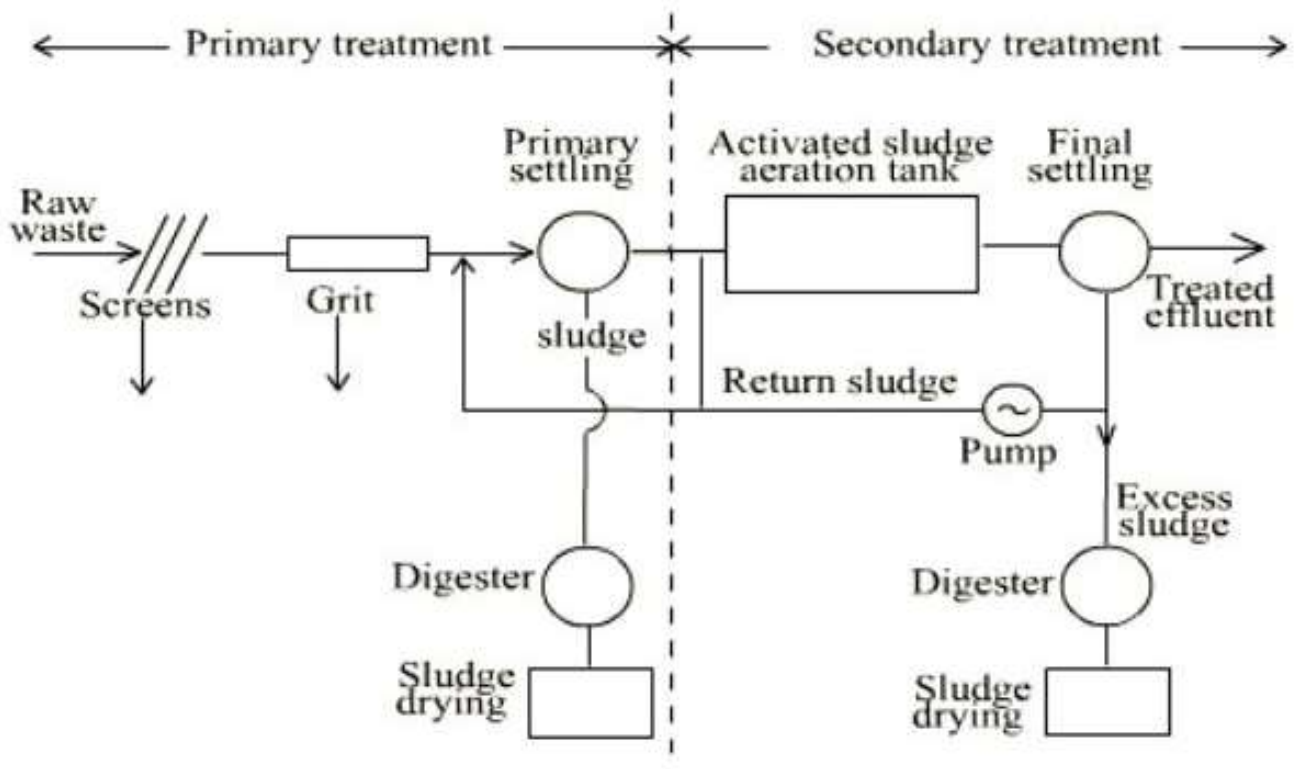

Figure 20: Activated Sludge Process (Indian Institute of Technology, India , 2016) 
Activated sludge plant involves:

1. wastewater aeration in the presence of a microbial suspension,

2. solid-liquid separation following aeration,

3. discharge of clarified effluent,

4. wasting of excess biomass, and

5. return of remaining biomass to the aeration tank.

During the activated sludge process wastewater containing organic matter is aerated in an aeration basin in which microorganisms metabolize the suspended and soluble organic matter. Some percentage of organic matter is synthesized into new cells and some part is oxidized to $\mathrm{CO}_{2}$ and water to derive energy. In activated sludge systems the new cells formed in the reaction are eliminated from the liquid stream in the form of a flocculent sludge in secondary clarifier settling tanks. A percentage of this settled biomass, described as activated sludge is returned to the aeration tank and the remaining percentage forms waste or excess sludge. (Indian Institute of Technology, India , 2016)

\section{Activated Sludge Process Variables}

The main variables of activated sludge process are the mixing regime, loading rate, and the flow scheme.

\section{Mixing Regime}

Generally, two types of mixing system are of major interest in activated sludge process: plug flow and complete mixing (Fig 21). In the plug flow, the system is characterized by orderly flow of mixed liquor through the aeration tank with no element of mixed liquor overtaking or mixing with any other element. There may be sideways mixing of mixed liquor but there must be no mixing along the path of flow.

In complete mixing, the substances of aeration tank are well stirred and uniform throughout. Thus, at steady state, the effluent from the aeration tank has the same composition as the aeration tank contents. 
The type of mixing system is very important as it affects (1) oxygen transfer requirements in the aeration tank, (2) susceptibility of biomass to shock loads, (3) local environmental conditions in the aeration tank, and (4) the kinetics governing the treatment process.

\section{Loading Rate}

A loading parameter that has been developed over the years is the hydraulic retention time (HRT), q, d

$\mathrm{q}=\mathrm{V} / \mathrm{Q}$

$\mathrm{V}=$ volume of aeration tank, $\mathrm{m}^{3}$, and $\mathrm{Q}=$ sewage inflow, $\mathrm{m}^{3} / \mathrm{d}$

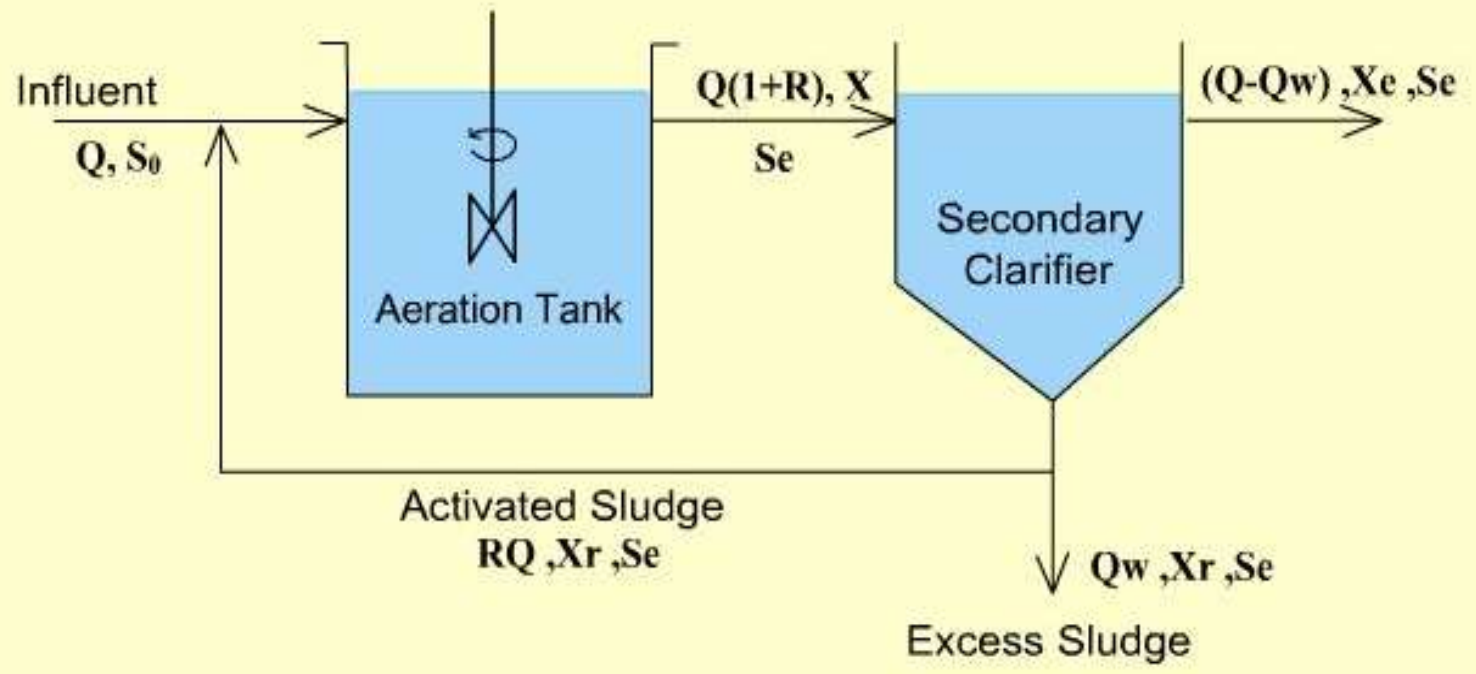

Figure 21: Completely Mixed Activated Sludge Process

Another empirical loading parameter is volumetric organic loading which is defined as the BOD applied per unit volume of aeration tank, per day. 
A rational loading parameter, which has found wider acceptance and is preferred is specific substrate utilization rate, $\mathrm{q}$, per day.

$\mathrm{q}=\underline{\mathrm{Q}}\left(\mathrm{S}_{\mathrm{O}}-\underline{\mathrm{S}_{\mathrm{e}}}\right)$

$\mathrm{V}$ X

A similar loading parameter is mean cell residence time or sludge retention time (SRT), $q_{c}, d$

$\mathrm{q}_{\mathrm{c}}=\frac{\mathrm{VX}}{\mathrm{Q}_{\mathrm{w}} \mathrm{X}_{\mathrm{r}}+\left(\mathrm{Q}_{-}-\mathrm{Q}_{\mathrm{w}} \mathrm{X}_{\mathrm{e}}\right)}$

where $S_{o}$ and $S_{e}$ are influent and effluent organic matter concentration respectively, measured as $\mathrm{BOD}_{5}\left(\mathrm{~g} / \mathrm{m}^{3}\right), \mathrm{X}, \mathrm{X}_{\mathrm{e}}$ and $\mathrm{X}_{\mathrm{r}}$ are MLSS concentration in aeration tank, effluent and return sludge respectively, and $\mathrm{Q}_{\mathrm{w}}=$ waste activated sludge rate.

Under steady state operation the mass of waste activated sludge is given by

$$
\mathrm{Q}_{\mathrm{w}} \mathrm{X}_{\mathrm{r}}=\mathrm{YQ}\left(\mathrm{S}_{\mathrm{O}}-\mathrm{S}_{\mathrm{e}}\right)-\mathrm{k}_{\mathrm{d}} \mathrm{XV}
$$

where $\mathrm{Y}=$ maximum yield coefficient (microbial mass synthesized / mass of substrate utilized) and $\mathrm{k}_{\mathrm{d}}=$ endogenous decay rate $\left(\mathrm{d}^{-1}\right)$.

From the above equation it is seen that $1 / \mathrm{q}_{\mathrm{c}}=\mathrm{Yq}-\mathrm{k}_{\mathrm{d}}$

If the value of $\mathrm{S}_{\mathrm{e}}$ is small as compared $\mathrm{S}_{\mathrm{O}}$, $\mathrm{q}$ may also be expressed as Food to Microorganism ratio, F/M

$\mathrm{F} / \mathrm{M}=\mathrm{Q}\left(\mathrm{S}_{\mathrm{O}}-\mathrm{S}_{\mathrm{e}}\right) / \mathrm{XV}=\mathrm{QS}_{\mathrm{O}} / \mathrm{XV}$

The $\mathrm{q}_{\mathrm{c}}$ value adopted for design controls the effluent quality, and settleability and drainability of biomass, oxygen requirement and quantity of waste activated sludge.

\section{Flow Scheme}

The flow scheme involves:

- the pattern of sewage addition 
- the pattern of sludge return to the aeration tank and

- the pattern of aeration.

Sewage addition may be at a single point at the inlet end or it may be at several points along the aeration tank. The sludge return may be directly from the settling tank to the aeration tank or through a sludge reaeration tank. Aeration may be at a uniform rate or it may be varied from the head of the aeration tank to its end.

\subsubsection{Trickling Filters}

Trickling filter is an attached growth process i.e. process in which microorganisms responsible for treatment are attached to an inert packing material. Packing material used in attached growth processes include, sand, redwood, rock, gravel, slag and a wide range of plastic and other artificially prepared materials.(Logan, Hermanowicz, \& Denny, 1987) (Harrison \& Daigger, 1987)

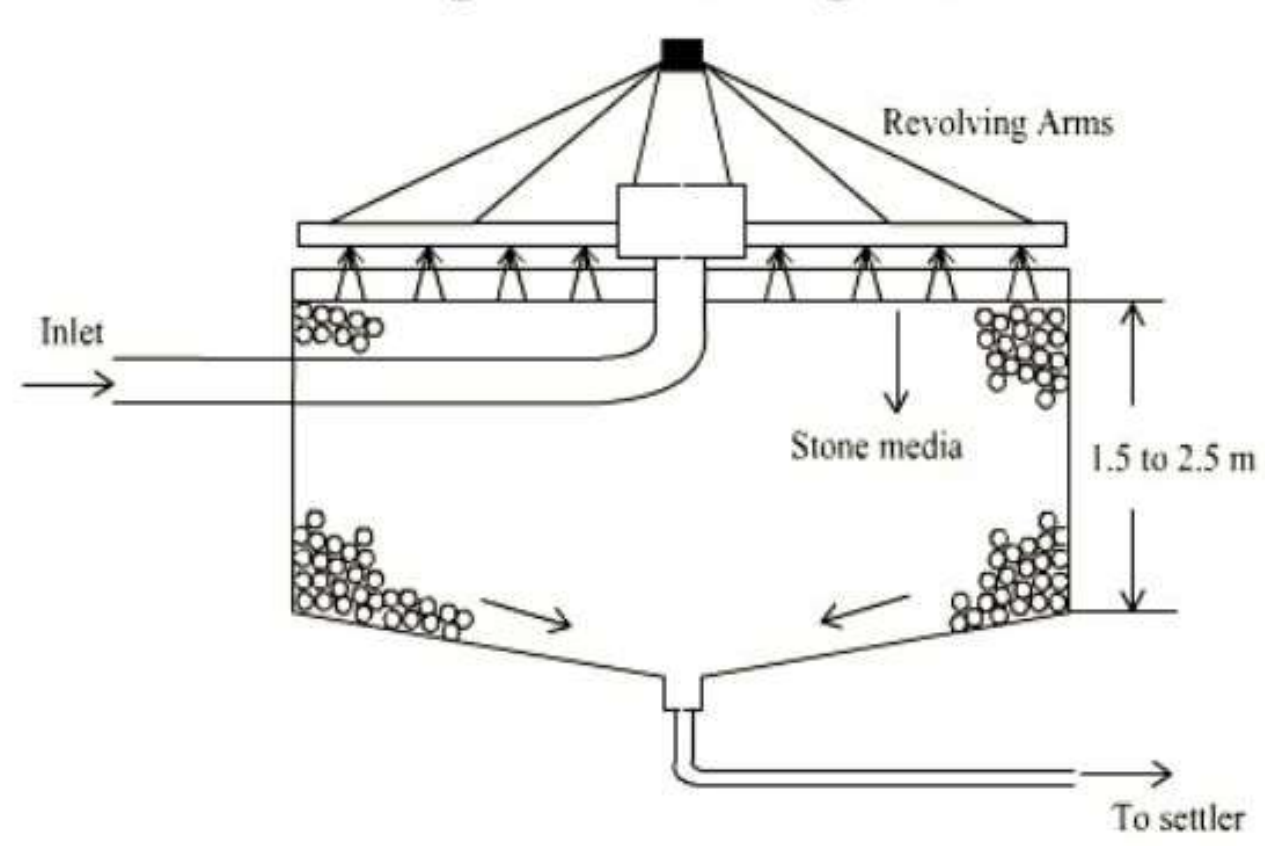

Figure 22: High Rate Trickling Filter 


\section{Process Description}

The wastewater in trickling filter is distributed over the top area of a vessel containing nonsubmerged packing material.

- Air circulation in the void space, by either natural draft or blowers, provides oxygen for the microorganisms growing as an attached biofilm.

- During operation, the organic material present in the wastewater is metabolised by the biomass attached to the medium. The biological slime grows in thickness as the organic matter abstracted from the flowing wastewater is synthesized into new cellular material.

- The depth of penetration of oxygen into the microbial layer limits the thickness of the aerobic layer.

- The micro-organisms near the medium face enter the endogenous phase as the substrate is metabolised before it can reach the micro-organisms near the medium face as a result of increased thickness of the slime layer and lose their ability to cling to the media surface. The liquid then washes the slime off the medium and a new slime layer starts to grow. This phenomenon of losing the slime layer is called sloughing.

The sloughed off film and treated wastewater are collected by an underdrainage which also allows circulation of air through filter. The collected liquid is passed to a settling tank used for solid- liquid separation.

\section{Types of Filters (Refer table 3)}

Trickling filters are classified as high rate or low rate, based on the organic and hydraulic loading applied to the unit.

Table 3 Types of Trickling Filters

\begin{tabular}{|l|l|l|l|}
\hline S. No & Design Feature & Low rate Filter & High Rate Filter \\
\hline 1 & Hydraulic loading, $\mathrm{m}^{3} / \mathrm{m}^{2} . \mathrm{d}$ & $1-4$ & $10-40$ \\
\hline 2 & Organic loading BOD $/ \mathrm{m}^{3} . \mathrm{d}$ & $0.08-0.32$ & $0.32-1.0$ \\
\hline 3 & Depth, $\mathrm{m}$. & $1.8-3.0$ & $0.9-2.5$ \\
\hline
\end{tabular}




\begin{tabular}{|l|l|l|l|}
\hline 4 & Recirculation ratio & 0 & $\begin{array}{l}0.5-3.0 \text { (domestic wastewater) upto } \\
8 \text { for strong industrial wastewater. }\end{array}$ \\
\hline
\end{tabular}

- The hydraulic loading rate is the total flow including recirculation applied on unit area of the filter in a day, while the organic loading rate is the 5 day $20^{\circ} \mathrm{C} \mathrm{BOD}$, excluding the BOD of the recirculant, applied per unit volume in a day.

- Recirculation is generally not adopted in low rate filters.

- A well operated low rate trickling filter in combination with secondary settling tank may remove 75 to $90 \%$ BOD and produce highly nitrified effluent. It is suitable for treatment of low to medium strength domestic wastewaters.

- The high rate trickling filter, single stage or two stage are recommended for medium to relatively high strength domestic and industrial wastewater. The BOD removal efficiency is around 75 to $90 \%$ but the effluent is only partially nitrified.

Single stage unit contains of a primary settling tank, filter, secondary settling tank and facilities for recirculation of the effluent. Two stage filters consist of two filters in series with a primary settling tank, an intermediate settling tank, which may be omitted in certain cases, and a final settling tank.

\section{Process Design}

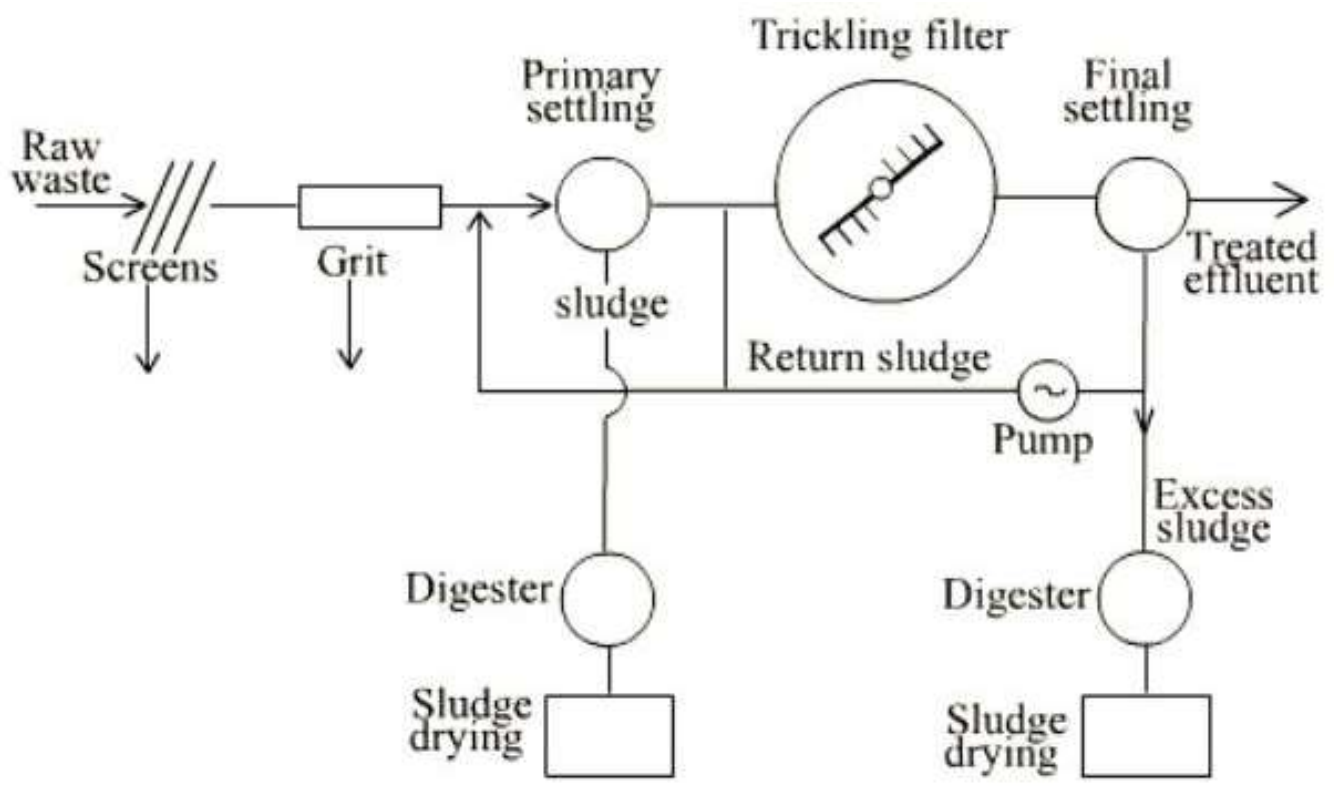

Figure 23: Flow Sheet of a Trickling Filter System (Indian Institute of Technology, India , 2016) 
Generally trickling filter design is based on empirical relationships to find the required filter volume for a designed degree of wastewater treatment. Types of equations:

1. NRC equations (National Research Council of USA)

2. Rankins equation

3. Eckenfilder equation

4. Galler and Gotaas equation

NRC and Rankin's equations are commonly used. NRC equations give satisfactory values when there is no re-circulation, the seasonal variations in temperature are not large and fluctuations with high organic loading. Rankin's equation is used for high rate filters.

NRC equations: These equations are applicable to both low rate and high rate filters. The efficiency of single stage or first stage of two stage filters, $E_{2}$ is given by

$$
\mathrm{E}_{2}=\frac{100}{1+0.44\left(F_{1 . B O D} / \mathrm{V}_{1} \cdot \mathrm{Rf}_{1}\right)^{1 / 2}}
$$

For the second stage filter, the efficiency $\mathrm{E}_{3}$ is given by

$$
\mathrm{E}_{3}=\frac{100}{\left[(1+0.44) /\left(1-\mathrm{E}_{2}\right)\right]\left(F_{2 . B O D} / \mathrm{V}_{2} \cdot \mathrm{Rf}_{2}\right)^{1 / 2}}
$$

where $E_{2}=\%$ efficiency in BOD removal of single stage or first stage of two-stage filter, $E_{3}=\%$ efficiency of second stage filter, $F_{1 . B O D}=$ BOD loading of settled raw sewage in single stage of the two-stage filter in $\mathrm{kg} / \mathrm{d}, F_{2 . B O D}=F_{1 . B O D}\left(1-\mathrm{E}_{2}\right)=$ BOD loading on second-stage filter in $\mathrm{kg} / \mathrm{d}$, $\mathrm{V}_{1}=$ volume of first stage filter, $\mathrm{m}^{3} ; \mathrm{V}_{2}=$ volume of second stage filter, $\mathrm{m}^{3} ; \mathrm{Rf}_{1}=$ Recirculation factor for first stage, $\mathrm{R}_{1}=$ Recirculation ratio for first stage filter, $\mathrm{Rf}_{2}=$ Recirculation factor for second stage, $\mathrm{R}_{2}=$ Recirculation ratio for second stage filter.

Rankins equation: This equation also known as Tentative Method of Ten States USA has been successfully used over wide range of temperature. It requires following conditions to be observed for single stage filters:

1. Raw settled domestic sewage BOD applied to filters should not exceed $1.2 \mathrm{~kg}$ $\mathrm{BOD}_{5} /$ day/ $\mathrm{m}^{3}$ filter volume. 
2. Hydraulic load (including recirculation) should not exceed $30 \mathrm{~m}^{3} / \mathrm{m}^{2}$ filter surface-day.

3. Recirculation ratio $(\mathrm{R} / \mathrm{Q})$ should be such that $\mathrm{BOD}$ entering filter (including recirculation) is not more than three times the BOD expected in effluent. This implies that as long as the above conditions are satisfied efficiency is only a function of recirculation and is given by:

$$
\mathrm{E}=\frac{(\mathrm{R} / \mathrm{Q})+1}{(\mathrm{R} / \mathrm{Q})+1.5}
$$

\subsubsection{Stabilization Ponds}

- The stabilization ponds are open flow through basins specifically designed and constructed to treat sewage and biodegradable industrial wastes. They provide long detention periods extending from a few to several days. (Mburu, Tebitendwa, Bruggen, Rousseau, \& Lens, 2013)

- Pond systems, in which oxygen is provided through mechanical aeration rather than algal photosynthesis are called aerated lagoons.

- Lightly loaded ponds used as tertiary step in waste treatment for polishing of secondary effluents and removal of bacteria are called maturation ponds.

\section{Classification of Stabilization Ponds}

Stabilization ponds may be aerobic, anaerobic or facultative.

- Aerobic ponds are shallow ponds with depth less than $0.5 \mathrm{~m}$ and BOD loading of 40$120 \mathrm{~kg} / \mathrm{ha}$.d so as to maximize penetration of light throughout the liquid depth. Such ponds develop intense algal growth.

- Anaerobic ponds are used as pre-treatment of high strength wastes with BOD load of 400-3000 kg/ha.d Such ponds are constructed with a depth of 2.5-5m as light penetration is unimportant.

- Facultative pond functions aerobically at the surface while anaerobic conditions prevail at the bottom. They are often about 1 to $2 \mathrm{~m}$ in depth. The aerobic layer acts as a good check against odour evolution from the pond. 


\section{Mechanism of Purification}

The functioning of a facultative stabilization pond and symbiotic relationship in the pond are shown below. Sewage organics are stabilized by both aerobic and anaerobic reactions. In the top aerobic layer, where oxygen is supplied through algal photosynthesis, the non-settleable and dissolved organic matter is oxidized to $\mathrm{CO}_{2}$ and water. In addition, some of the end products of partial anaerobic decomposition such as volatile acids and alcohols, which may permeate to upper layers are also oxidized periodically. The settled sludge mass originating from raw waste and microbial synthesis in the aerobic layer and dissolved and suspended organics in the lower layers undergo stabilization through conversion to methane which escapes the pond in form of bubbles. Refer to fig 24 .

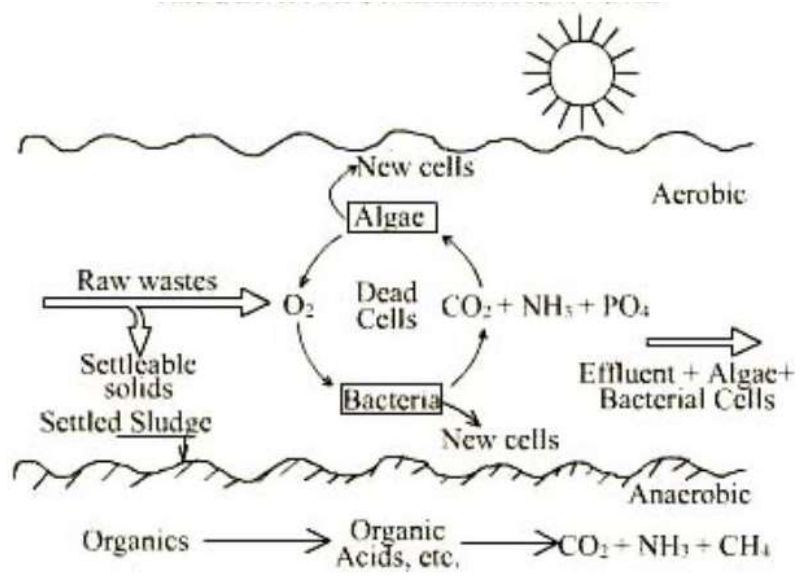

Figure 24: Symbiotic Relationship and Functioning of Facultative Stabilization Pond (Indian Institute of Technology, India , 2016)

\section{Factors Affecting Pond Reactions}

Various factors affect pond design:

- wastewater characteristics and fluctuations.

- environmental factors (solar radiation, light, temperature)

- algal growth patterns and their diurnal and seasonal variation)

- bacterial growth patterns and decay rates.

- solids settlement, gasification, upward diffusion, sludge accumulation. 
The depth of aerobic layer in a facultative pond is a function of solar radiation, waste characteristics, loading and temperature. As the organic loading is increased, oxygen production by algae falls short of the oxygen requirement and the depth of aerobic layer decreases. Further, there is a decrease in the photosynthetic activity of algae because of greater turbidity and inhibitory effect of higher concentration of organic matter.

Gasification of organic matter to methane is carried out in distinct steps of acid production by acid forming bacteria and acid utilization by methane bacteria. If the second step does not proceed satisfactorily, there is an accumulation of organic acids resulting in decrease of $\mathrm{pH}$ which would result in complete inhibition of methane bacteria. Two possible reasons for imbalance between activities of methane bacteria are: (1) the waste may contain inhibitory substances which would retard the activity of methane bacteria and not affect the activity of acid producers to the same extent. (2) The activity of methane bacteria decreases much more rapidly with fall in temperature as compared to the acid formers.

Thus, year round warm temperature and sunshine provide an ideal environment for operation of facultative ponds.

\section{Algal Growth and Oxygen Production}

Algal growth converts solar energy to chemical energy in the organic form. Empirical studies have shown that generally about $6 \%$ of visible light energy can be converted to algal energy. The chemical energy contained in an algal cell averages 6000 calories per gram of algae. Depending on the sky clearance factor for an area, the average visible radiation received can be estimated as follows:

Avg. radiation $=$ Min. radiation $+[($ Max. radiation - Min. radiation $) \mathrm{x}$ sky clearance factor $]$

Oxygen production occurs concurrently with algal production in accordance with following equation:

$106 \mathrm{CO}_{2}+16 \mathrm{NO}_{3}+\mathrm{HPO}_{4}+122 \mathrm{H}_{2} \mathrm{O}+18 \mathrm{H}^{+} \longrightarrow \mathrm{C}_{106} \mathrm{H}_{263} \mathrm{O}_{110} \mathrm{~N}_{16} \mathrm{P}_{1}+138 \mathrm{O}_{2}$

On weight basis, the oxygen production is 1.3 times the algal production. 


\section{Areal Organic Loading}

The permissible areal organic loading for the pond expressed as $\mathrm{kg}$ BOD/ha.day will depend on the minimum incidence of sunlight that can be expected at a location and also on the percentage of influent BOD that would have to be satisfied aerobically. The Bureau of Indian Standards has related the permissible loading to the latitude of the pond location to aerobically stabilize the organic matter and keep the pond odour free. The values are applicable to towns at sea levels and where sky is clear for nearly $75 \%$ of the days in a year. The values may be modified for elevations above sea level by dividing by a factor $(1+0.003 \mathrm{EL})$ where EL is the elevation of the pond site above MSL in hundred meters. (Elbeshbishy, 2016) (Indian Institute of Technology, India , 2016)

\section{Detention Time}

The flow of sewage can approximate either plug flow or complete mixing or dispersed flow. If BOD exertion is described by first order reaction, the pond efficiency is given by:

for plug flow: $\mathrm{L}_{\mathrm{e}} / \mathrm{L}_{\mathrm{i}}=\mathrm{e}^{-\mathrm{k} 1 \mathrm{t}}$

for complete mixing: $\mathrm{L}_{\mathrm{e}} / \mathrm{L}_{\mathrm{i}}=\underline{1}$

$$
1+\mathrm{k}_{1} \mathrm{t}
$$

For dispersed flow the efficiency of treatment for different degrees of intermixing is characterized by dispersion numbers. Choice of a larger value for dispersion number or assumption of complete mixing would give a conservative design and is recommended.

\section{Depth}

Having determined the surface area and detention capacity, it becomes necessary to consider the depth of the pond only in regard to its limiting value. The optimum range of depth for facultative ponds is $1.0-1.5 \mathrm{~m}$.

\subsubsection{Anaerobic Sludge Digestion}

Anaerobic digestion may be considered beneficial for sludge stabilization when the sludge volatile solids content is $50 \%$ or higher and if no inhibitory substances are present or 
expected. Conversion rates during anaerobic treatment of soluble substrates are generally described by Monod kinetics (Pavlostathis and Giraldo-Gómez, 1991; van Haandel and Lettinga, 1994). Recently, prospects of multi-phase digestion have become more promising compared to single stage digestion. In conventional single phase digester, the acidogenic and methanogenic microorganisms are kept in a single reactor. Both groups of microorganisms are different in terms of physiology, $\mathrm{pH}$ requirement, nutrient requirement, growth kinetics, ability to tolerate environmental conditions (Demirel and Yenigün, 2002; Demirer and Chen, 2005). Favorable operating conditions such as shorter HRT and lower $\mathrm{pH}$ for acid-forming bacteria are not suitable for methane-forming bacteria (Demirer and Chen, 2005). Therefore, it is very difficult to provide an optimum condition for different groups of microorganisms in a conventional single stage digester. Several studies have shown that two-phase digestion is more effective for high solid containing waste (Chanakya et al., 1992; Argelier et al., 1998, MataAlvarez et al., 2000).

Anaerobic digestion of primary sludge is preferred over activated sludge because of the poor solids-liquid separation characteristics of activated sludges. Combining primary and secondary sludges will result in settling characteristics better than activated sludge but less desirable than primary alone. Chemical sludges containing lime, alum, iron, and other substances can be successfully digested if the volatile solids content remains high enough to support the biochemical reactions and no toxic compounds are present. If an examination of past sludge characteristics indicates wide variations in sludge quality, anaerobic digestion may not be feasible because of its inherent sensitivity to changing substrate quality. The following is a list of sludges, which are suitable for anaerobic digestion:

1. Primary and lime;

2. Primary and ferric chloride;

3. Primary and alum;

4. Primary and trickling filter;

5. Primary, trickling filter, and alum;

6. Primary and waste activated;

7. Primary, waste activated, and lime;

8. Primary, waste activated, and alum;

9. Primary, waste activated, and ferric chloride; and

10. Primary, waste activated, and sodium aluminate. 


\section{Advantages}

The advantages offered by anaerobic digestion include (Ward, Hobbs, Holliman, \& Jones, 2008), (Metcalf \& Eddy, 2002) (Tsonis \& Grigoropoulos, 1993)

1. Excess energy over that required by the process is produced. Methane is produced and can be used to heat and mix the reactor. Excess methane gas can be used to heat space or produce electricity, or as engine fuel;

2. The quantity of total solids for ultimate disposal is reduced. The volatile solids present are converted to methane, carbon dioxide, and water thereby reducing the quantity of solids. About 30 to $40 \%$ of the total solids may be destroyed and 40 to $60 \%$ of the volatile solids may be destroyed;

3. The product is a stabilized sludge that may be free from strong or foul odours and can be used for land application as ultimate disposal because the digested sludge contains plant nutrients;

4. Pathogens are destroyed to a high degree during the process. Thermophilic digestion enhances the degree of pathogen destruction; and

5. Most organic substances found in municipal sludge are readily digestible except lignin, tannins, rubber, and plastics.

\section{Disadvantages}

The disadvantages associated with anaerobic digestion include:

1. The digester is easily upset by unusual conditions and erratic or high loadings and very slow to recover;

2. Operators must follow proper operating procedures;

3. Heating and mixing equipment are required for satisfactory performance

4. Large reactors are required because of the slow growth of methanogens and required solid retention times (SRT's) of 15 to 20 days for a high-rate system. Thus capital cost is high.

5. The resultant supernatant side stream is a strong waste stream that greatly adds to the loading of the wastewater plant. It contains high concentrations of BOD, COD, suspended solids and ammonia nitrogen;

6. Cleaning operations are difficult because of the closed vessel. Internal heating and mixing equipment can become major problems as a result of corrosion and wear in harsh inaccessible environments.

7. A sludge poor in dewatering characteristics is produced; 
8. The possibility of explosion as a result of inadequate operation and maintenance, leaks, or operator carelessness exists; and

9. Gas line condensation or clogging can cause major maintenance problems. (Pavlostathis \& Giraldo-Gomez, 1991) (Ward, Hobbs, Holliman, \& Jones, 2008)

\section{Digestion Tanks and Number of Stages}

With anaerobic sludge digestion facilities, the need for multiple units can often be avoided by providing two-stage digestion along with sufficient flexibility in sludge pumpage and mixing so that one stage can be serviced while the other stage receives the raw sludge pumpage. Single stage digesters will generally not be satisfactory due to the usual need for sludge storage, and effective supernating. They will be considered, however, where the designer can show that the above concerns can be satisfied and that alternate means of sludge processing or emergency storage can be used in the event of breakdown.

Typical Sludge Qualities and Generation Rates for Different Unit Processes When reliable data are not available, the sludge generation rates and characteristics given in Table 3 below may be used (Demirer \& Chen, 2005). (Demirel \& Yenigün, 2002) 
Table 4: Typical Sludge Qualities and Generation Rules

\begin{tabular}{|c|c|c|c|c|c|c|}
\hline \multirow[t]{2}{*}{ Unit Process } & \multirow{2}{*}{$\begin{array}{l}\text { Liquid } \\
\text { Sludge } \\
\text { L/Cum }\end{array}$} & \multicolumn{2}{|c|}{$\begin{array}{l}\text { Solids } \\
\text { Concentration }\end{array}$} & \multirow{2}{*}{$\begin{array}{l}\text { Volatile } \\
\text { Solids } \\
(\%)\end{array}$} & \multicolumn{2}{|c|}{ Dry Solids } \\
\hline & & $\begin{array}{l}\text { Range } \\
(\%)\end{array}$ & $\begin{array}{l}\text { Average } \\
(\%)\end{array}$ & & $\mathrm{g} / \mathrm{Cum}$ & g/cap.d \\
\hline \multicolumn{7}{|c|}{ Primary Sedimentation with Anaerobic Digestion } \\
\hline $\begin{array}{l}\text { Undigested (no P } \\
\text { removal) }\end{array}$ & 2.0 & $1.5-8$ & 5.0 & 65 & 120 & 55 \\
\hline $\begin{array}{l}\text { Undigested (With P } \\
\text { removal) }\end{array}$ & 3.2 & $3.5-7$ & 4.5 & 65 & 170 & 77 \\
\hline digested (no P removal) & 1.1 & $5-13$ & 6.0 & 50 & 75 & 34 \\
\hline $\begin{array}{l}\text { digested (With } \mathrm{P} \\
\text { removal) }\end{array}$ & 1.6 & $5-13$ & 5.0 & 50 & 110 & 50 \\
\hline \multicolumn{7}{|c|}{ Primary Sedimentation and conventional Activated Sludge with Anaerobic Digestion } \\
\hline $\begin{array}{l}\text { Undigested (no P } \\
\text { removal) }\end{array}$ & 4.0 & $2-7$ & 4.5 & 65 & 160 & 62 \\
\hline $\begin{array}{l}\text { Undigested (With P } \\
\text { removal) }\end{array}$ & 5.0 & $2-6.5$ & 4.0 & 60 & 220 & 100 \\
\hline digested (no P removal) & 2.0 & $2-6$ & 5.0 & 50 & 115 & 52 \\
\hline $\begin{array}{l}\text { digested (With P } \\
\text { removal) }\end{array}$ & 3.5 & $2-6$ & 4.0 & 45 & 150 & 68 \\
\hline \multicolumn{7}{|c|}{ Contact Stabilization and High rate with anaerobic Digestion } \\
\hline $\begin{array}{l}\text { Undigested (no P } \\
\text { removal) }\end{array}$ & 15.5 & $0.4-2.6$ & 1.1 & 70 & 170 & 77 \\
\hline $\begin{array}{l}\text { Undigested (With P } \\
\text { removal) }\end{array}$ & 19.1 & $0.4-2.6$ & 1.1 & 60 & 210 & 95 \\
\hline digested (no P removal) & 6.1 & $1-3$ & 1.9 & 70 & 115 & 52 \\
\hline $\begin{array}{l}\text { digested (With } \mathrm{P} \\
\text { removal) }\end{array}$ & 8.1 & $1-3$ & 1.9 & 60 & 155 & 70 \\
\hline \multicolumn{7}{|c|}{ Extended Aeration with Aerated Sludge Holding Tank } \\
\hline $\begin{array}{l}\text { Waste Activated (no P } \\
\text { removal) }\end{array}$ & 10.0 & $0.4-1.9$ & 0.9 & 70 & 90 & 41 \\
\hline $\begin{array}{l}\text { Waste Activated ( P } \\
\text { removal) }\end{array}$ & 13.3 & $1.4-1.9$ & 0.9 & 60 & 120 & 55 \\
\hline $\begin{array}{l}\text { Sludge Holding Tank( } \\
\text { no P removal) }\end{array}$ & 4.0 & $1.4-5.0$ & 2.0 & 70 & 80 & 36 \\
\hline $\begin{array}{l}\text { Sludge Holding Tank( } \\
\text { no P removal) }\end{array}$ & 5.5 & $0.4-4.5$ & 2.0 & 60 & 110 & 50 \\
\hline $\begin{array}{ll}\circ & \text { L/Cum de } \\
& \text { sewage } \\
\circ & \mathrm{g} / \text { Cum de } \\
\circ & \text { the above } \\
& \mathrm{mg} / \mathrm{l}, \mathrm{solu} \\
\end{array}$ & $\begin{array}{l}\text { tes gram } \\
\text { alues are }\end{array}$ & $\begin{array}{l}\text { of liquid } \\
\text { s of dry } \mathrm{s} \\
\text { based on } \\
0, \mathrm{SS}=2\end{array}$ & $\begin{array}{l}\text { udge per cr } \\
\text { ds per cub } \\
\text { pical raw s } \\
\mathrm{mg} / \mathrm{L}, \mathrm{P}=7\end{array}$ & $\begin{array}{l}\text { chic me } \\
\text { c meter } \\
\text { ewage }\end{array}$ & $\begin{array}{l}\text { of treate } \\
\text { treated } \\
\mathrm{h} \text { total } \mathrm{BC} \\
\mathrm{i} 3=20 \mathrm{~ms}\end{array}$ & $\begin{array}{l}\text { ewage } \\
\mathrm{OD}=570 \\
/ \mathrm{L}\end{array}$ \\
\hline
\end{tabular}




\section{Solids Retention Time}

The minimum solids retention time for a low rate digester shall be 30 days. The minimum solids retention time of a high rate digester shall be 15 days.

\section{Design of Tank Elements}

Digester Shape Anaerobic digesters are generally cylindrical in shape with inverted conical bottoms. Choosing a proper depth-diameter ratio can minimize heat loss from digesters, such that the total surface area is the least for a given volume. A cylinder with diameter equal to depth can be shown to be the most economical shape from heat loss viewpoint. However, structural requirements and scum control aspects also govern the optimum depth-diameter ratio.

\section{Floor Slope}

To facilitate draining, cleaning and maintenance, the following features are desirable:

1. The tank bottom should slope to drain toward the withdrawal pipe;

2. For tanks equipped with mechanisms for withdrawal of sludge, a bottom slope not less than 1:12 (vertical: horizontal) is recommended; and

3. Where the sludge is to be removed by gravity alone, 1:4 slope is recommended.

\section{Depth and Freeboard}

For those units proposed to serve as supernatant development tanks, the depth should be sufficient to allow for the formation of a reasonable depth of supernatant liquor. A minimum water depth of $6 \mathrm{~m}$ is recommended. The acceptable range for sidewater depth is between 6 and $14 \mathrm{~m}$.

The freeboard provided must take into consideration the type of cover and maximum gas pressure. For floating covers, the normal working water level in the tank under gas pressure is approximately $0.8 \mathrm{~m}$ below the top of the wall, thus providing from 0.5 to $0.6 \mathrm{~m}$ of freeboard between the liquid level and the top of the tank wall. For fixed flat slab roofs, a freeboard of 0.3 to $0.6 \mathrm{~m}$ above the working liquid level is commonly provided. For fixed conical or domed roofs, the freeboard between the working liquid level and the top of the wall inside the tank can be reduced to less than $0.3 \mathrm{~m}$. 


\section{Scum Control}

Including any of the following provisions in the equipment design can control scum accumulation:

1. Floating covers keep the scum layer submerged and thus moist and more likely to be broken up;

2. Discharging re-circulated sludge on the scum mat serves the same purpose as (1);

3. Re-circulating sludge gas under pressure through the tank liquors and scum;

4. Mechanically destroying the scum by employing rotating arms or a propeller in a draft tube;

5. A large depth-area ratio; or

6. A concentrated sludge feed to the digester.

Items (5) and (6) would release large volumes of gas per unit area, keep the scum in motion and mix the solids in the digester.

\section{Grit and Sand Control}

The digesters should be designed to minimize sedimentation of the particles and facilitate removal if settling takes place. These objectives can be achieved if tank contents are kept moving at 0.23 to $0.3 \mathrm{~m} / \mathrm{s}$ and the floor slopes are about $1: 4$.

\section{Alkalinity and PH Control}

The effective $\mathrm{pH}$ range for methane producers is approximately 6.5 to 7.5 with an optimum range of 6.8 to 7.2. Maintenance of this optimum range is important to ensure good gas production and to eliminate digester upsets.

The stability of the digestion process depends on the buffering capacity of the digester contents; the ability of the digester contents to resist $\mathrm{pH}$ changes. The alkalinity is a measure of the buffer capacity of a freshwater system. Higher alkalinity values indicate a greater capacity for resisting $\mathrm{pH}$ changes. The alkalinity shall be measured as bicarbonate alkalinity. Values for alkalinity in anaerobic digesters range from 1500 to $5000 \mathrm{mg} / \mathrm{L}$ as $\mathrm{CaCO}$. The volatile acids produced by the acid producers tend to depress $\mathrm{pH}$. Volatile acid concentrations under stable conditions range from 100 to $500 \mathrm{mg} / \mathrm{L}$. Therefore, a constant ratio below 0.25 of volatile acids 
to alkalinity shall be maintained so that the buffering capacity of the system can be maintained. Sodium bicarbonate, lime, sodium carbonate, and ammonium hydroxide application are recommended for increasing alkalinity of digester contents

\subsection{Advanced Treatment:}

It is an additional treatment processes, such as filtration, carbon adsorption, chemical precipitation of phosphorus, to remove those constituents that are not adequately removed in the secondary treatment plant. These include nitrogen, phosphorus, and other soluble organic and inorganic compounds.

\subsubsection{Nutrients Recovery}

It is summary of nitrogen and phosphorus recovery and the potential agriculture utilization in the economic conditions of decreasing world phosphorus resources. Phosphorus recovery methods discussed in the chapter are grouped according to the type of mainstream P removal process (i.e. EBPR or chemical) and point of recovery (i.e. biosolids, SDL, mainstream, ash). Nitrogen and phosphorus are essential to life and cannot be substituted. Nitrogen is assimilated by plants and can be easily synthesized by the conventional Haber-Bosch process (Cornel and Schaum 2009). Phosphorus on the other hand is obtained from phosphate rock from reserves, which will be depleted within this century as the population increases to 10 billion people. Some $80 \%$ of mined phosphorus is used in agriculture where the application of P-fertilizer increases with the affluence of developing nations resulting in accelerated consumption of phosphorus.

Canada's population approaching 36 million discharges some 43,000 tons of phosphorus in municipal wastewater per year. Recovery of this phosphorus as $\mathrm{P} 2 \mathrm{O} 5$ fertilizer would lead to reduction of some 1 million tons of greenhouse gases (CEEP, 2008) and a revenue stream that could offset the costs of nutrient removal (Algeo and O'Callaghan, 2012). A number of European countries such as Germany and Sweden have announced national objectives for phosphorus recovery from municipal wastewater. Phosphorus recovery is now included in UK Environment Agency's strategy. (Damian Kruk, 2015) (Federation of Canadian Municipalities and National Research Council, 2003).

Phosphorus and nitrogen concentrations in raw municipal wastewater depend on unit water consumption and range from 4 to $20 \mathrm{mg} \mathrm{TP} / \mathrm{L}$ and from 30 to $100 \mathrm{mg} \mathrm{TN} / \mathrm{L}$. The concentrations in side streams depend on the method of solids treatment and vary from 30 to $250 \mathrm{mg} \mathrm{TP} / \mathrm{L}$ and 200 to $2000 \mathrm{mg}$ TN/L. Figure 25 presents the main steps required for nutrients recovery and reuse. Nutrient removal can be in the form of concentration in the biomass such as in 
activated sludge or algae, or physicochemical concentration into precipitate or adsorption on media

That material can then be used directly for land application as is. Should precipitation yield a marketable product - the precipitate can be sold as fertilizer. Otherwise the concentrated material has to be re-solubilized using biological or physico-chemical methods and phosphorus then extracted from the liquid.

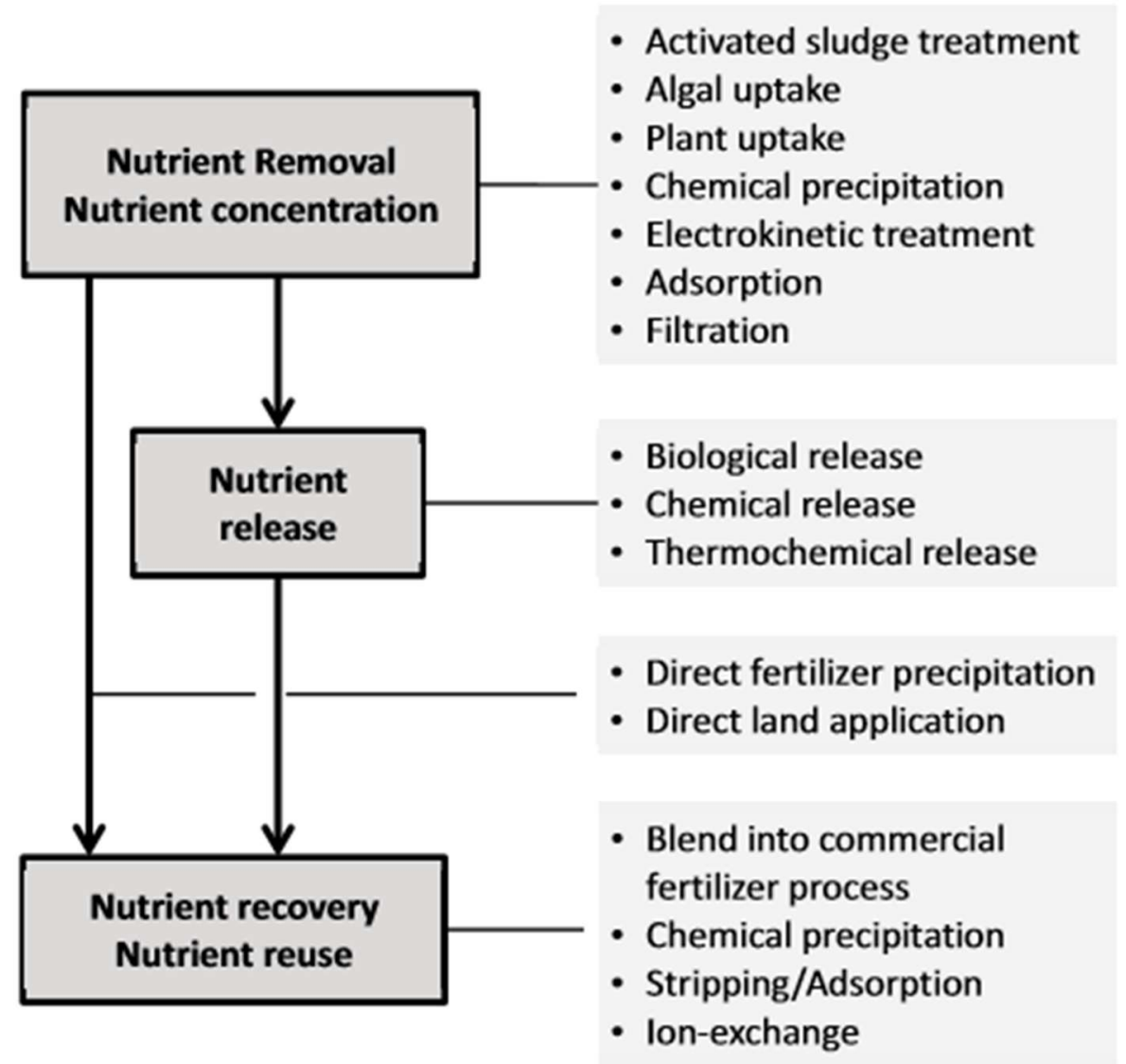

Figure 25: The Three Main Steps in Nutrient Recovery and Reuse (Federation of Canadian Municipalities and National Research Council, 2003)

In spite of importance of nutrient recovery, only a handful of WWTPs in North America have implemented extractive phosphorus recovery. According to the conducted survey, among 69 responding WWTPs only $4.6 \%$ are currently recovering nutrients and only $26.2 \%$ are planning extractive recovery in the future. The participants mentioned lack of economic drivers and regulations as the main reasons against implementing recovery units. The widespread application of recovery technologies depends on the market, regulations and is site-specific. Making legal obligations by policy makers along with long term benefits coming from 
economic analysis should provide the required driving factors to start the phosphorus recovery economy.

Review of data from existing municipal facilities in North America indicated that influent phosphorus concentration in municipal wastewater are in the range of 2 to $9 \mathrm{mg} / \mathrm{L}$, with a Nutrient average concentration of $6 \mathrm{mg} / \mathrm{L}$. Approximately $10 \%$ of the incoming phosphorus load is removed with the primary sludge (Cornel and Schaum 2009). Generally speaking, in a biological wastewater treatment approximately $30 \%$ of the incoming phosphorus is incorporated into the biomass and removed with waste activated sludge, without specific phosphorus removal processes. In a nutrient removal plant, based on the permitted discharge concentration of 0.1 to $1 \mathrm{mg} / \mathrm{L}$, additional $50 \%$ of the incoming phosphorus load has to be removed specifically, either by biological or chemical-physical phosphorus removal process or their combination. This means approximately 95\% of the incoming phosphorus load is incorporated into the wastewater sludge (Cornel and Schaum 2009). A rough phosphorus balance for a typical municipal wastewater treatment plant is shown in Figure 26. The numbers illustrate maximum potential for phosphorus recovery. The recovery technologies are typically 90-95\% efficient (Federation of Canadian Municipalities and National Research Council, 2003)

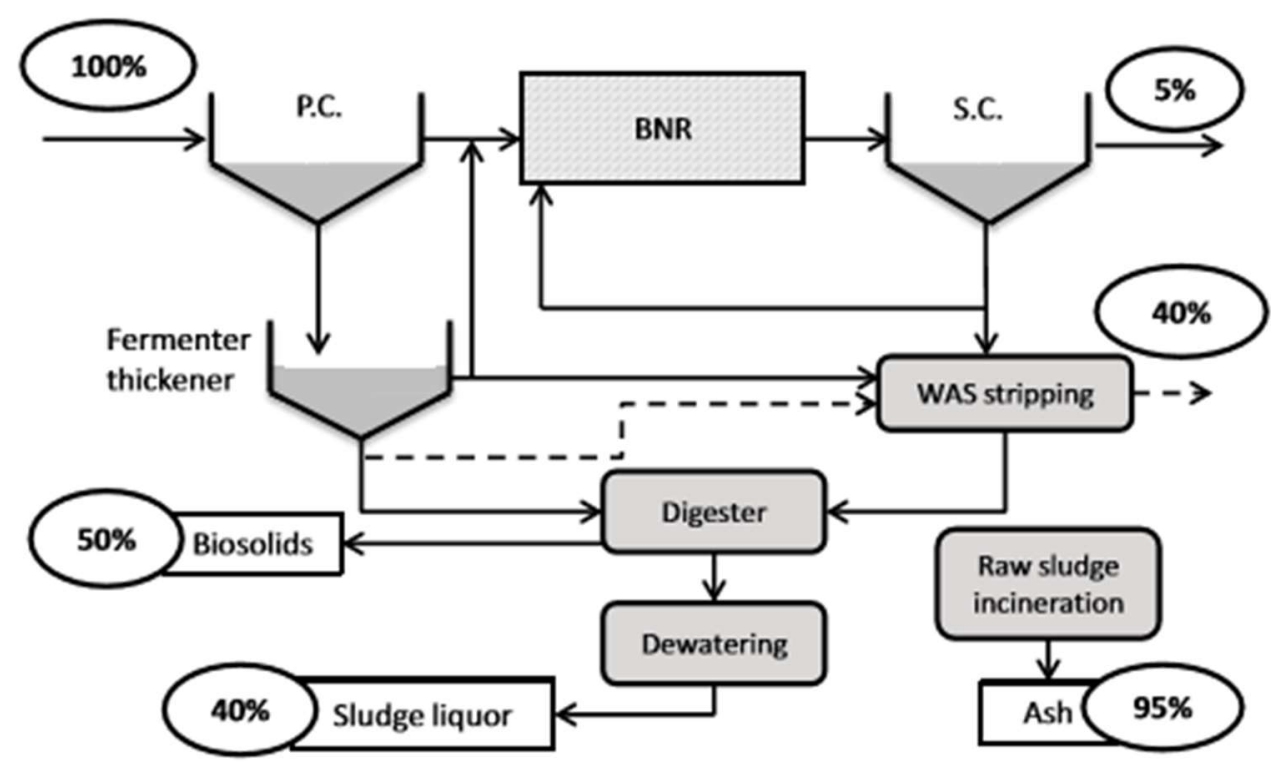

Figure 26: Potentially Recoverable Phosphorous at Various Points in a Typical WWTP (Federation of Canadian Municipalities and National Research Council, 2003) 
In North America the influent nitrogen concentration in municipal wastewater are in the range of 25 to $50 \mathrm{mg} / \mathrm{L}$, with an average concentration of $40 \mathrm{mg} / \mathrm{L}$. In a biological nutrient removal wastewater treatment approximately $65 \%$ of the incoming nitrogen is removed through nitrification and denitrification process. Based on the permitted discharge concentration of 1 to $15 \mathrm{mg} / \mathrm{L}$, with typical concentration of $10 \mathrm{mg} / \mathrm{L}$, approximately $10 \%$ of the incoming nitrogen load ends up in the effluent. Almost $25 \%$ of the incoming ammonia load is incorporated into the wastewater sludge. A rough nitrogen balance for a typical municipal wastewater treatment plant is shown in Figure 27.

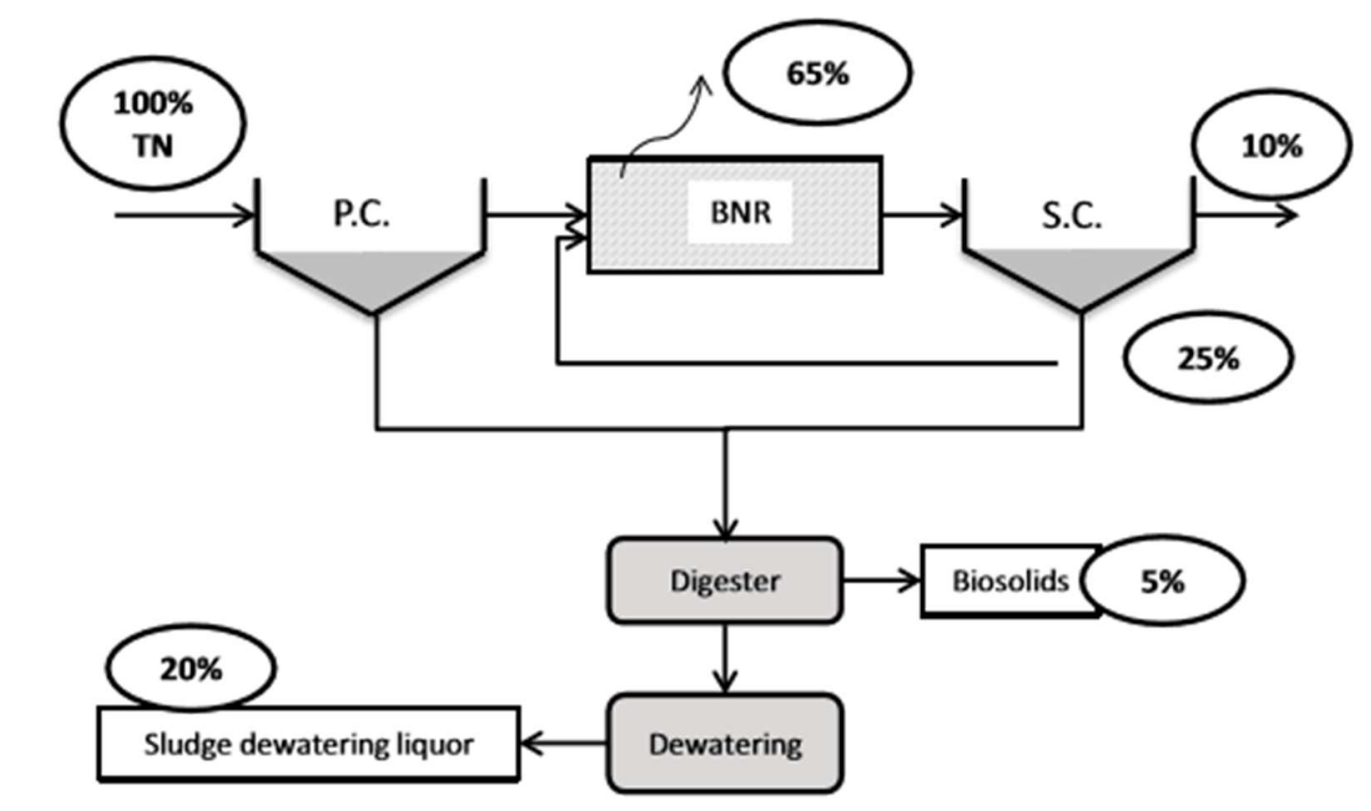

Figure 27: Potentially Recoverable Nitrogen at Various Points in a Typical WWT (Federation of Canadian Municipalities and National Research Council, 2003)

As illustrated in both $\mathrm{P}$ and $\mathrm{N}$ mass balance graphs, nutrient loading from sludge handling processes in the sidestream can be very significant for the mainstream removal processes. Plants have reported return nitrogen loads as high as $35 \%$ of the incoming load. High concentrations of phosphorus in the sidestream also results in increased operational and maintenance costs due to maintenance problems from phosphorus precipitation. Therefore, a dedicated recovery system in the sidestream, can benefit mainstream treatment and allow nutrient recovery. For effluent TP limits of less than $1 \mathrm{mg} / \mathrm{L}$ in the effluent the removal, and possibly recovery, of phosphorus from the sidestream is mandatory for process stability (Clark et al., 2014). 
Wastewater treatment could remove up to $95 \%$ of the phosphorus from municipal wastewater and concentrate it into sewage sludge which after treatment can be applied to land as fertilizer or can be recovered in the sidestream using chemicals (Khunjar et al., 2013). Restriction ofland application of biosolids due to high concentrations of phosphorus in relation to nitrogen or high levels of metals makes removal and recovery of phosphorus from biosolids a logical and sustainable solution. Nutrients can be recovered from nutrient-rich side streams, sewage sludge and sewage sludge ash. Recovery of phosphorus from side streams (centrate or filtrate) can yield up to $40 \%$ of the influent phosphorus. Recovering phosphorus from sewage sludge or sludge ash up to $90 \%$ of the influent phosphorus could be obtained (Cornel and Schaum 2009). A number of technologies are available for recovering nutrients from sidestream or from biosolids. They can be divided into six groups: (1) recovery of $\mathrm{N}$ or P from sludge generated in a biological process which includes recovery from centrate, filtrate, supernatant, fermented or digested sludge; (2) recovery of $\mathrm{N}$ or P from chemical sludge; (3) recovery of $\mathrm{P}$ from ash; (4) recovery of $\mathrm{N}$ and $\mathrm{P}$ from mainstream; (5) nitrogen recovery only as through ammonia stripping or ion exchange; and (6) recovery from source separated urine. A summary of the nutrient recovery processes discussed in this chapter is presented in Figure 28.

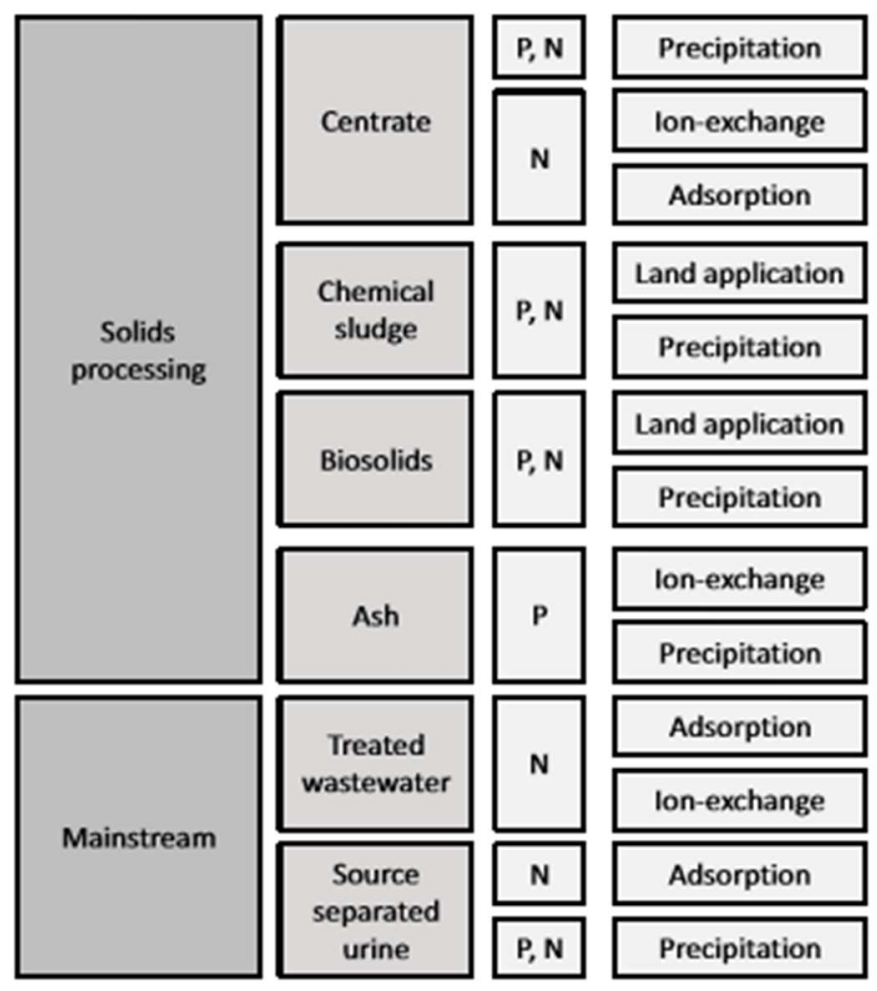

Figure 28: Options for Nutrient Recovery 
The main methods of nutrient (mainly phosphorus) recovery from sludge or sludge ash are presented in Table 5.

Table 5: Mechanisms of Phosphorous Recovery (Federation of Canadian Municipalities and National Research Council, 2003)

\begin{tabular}{|l|l|}
\hline Release of Phosphorus & Recovered Elements \\
\hline $\begin{array}{l}\text { Precipitating the released phosphorous } \\
\text { from EBPR sludge through aerobic or } \\
\text { anaerobic digestion, VFA stripping or } \\
\text { media regeneration }\end{array}$ & $\mathrm{P}, \mathrm{N}, \mathrm{Mg}$ \\
\cline { 2 - 2 } & $\mathrm{P}, \mathrm{Ca}$ \\
\hline $\begin{array}{l}\text { Using acid to solubilize nutrients in } \\
\text { digested sludge and producing a nutrient } \\
\text { rich filtrate after dewatering }\end{array}$ & $\mathrm{P}, \mathrm{N}, \mathrm{Mg}$ \\
\hline Using acid to nutrients from sludge ash & $\mathrm{P}, \mathrm{Ca}, \mathrm{Al}$ \\
\hline $\begin{array}{l}\text { Adding potassium and magnesium } \\
\text { chloride to ash and heating the mixture } \\
\text { to more than } 100 \text { degrees centigrade }\end{array}$ & $\mathrm{P}, \mathrm{K}, \mathrm{Mg}$ \\
\hline
\end{tabular}

\subsubsection{Phosphorous Recovery from Sludge Originating from a Biological Process}

\section{Phosphorus recovery from biosolids}

Biological phosphorus removal is achieved by enrichment of PAOs in the activated sludge. The selection of PAOs acts to increase the net phosphorus concentration within biological solids. Phosphorus is then removed from wastewater by wasting biological solids, including PAOs, from the mainstream as WAS. The phosphorus-enriched WAS is, potentially, a form of recovered phosphorus that can be applied to land as fertilizer. WAS from non-BNR systems can also be land applied as fertilizer, replenishing both nitrogen and phosphorus. The meaningful recovery and reuse of nutrients can thus be achieved without extractive recovery systems and should be considered in design when the municipality cannot feasibly meet the capital cost of extractive recovery technologies. Biosolids for land application need to be stabilized and disinfected. A number of treatment technologies are available e.g. Lystek, NViro, VitAG, Neutrallizer and Schwing-Bioset process etc. The Lystek process uses high $\mathrm{pH}$ alkali high-temperature treatment generating a liquid product LysteGroTM (Figure 29). This 
liquid fertilizer has very high phosphorus to nitrogen ratio $(\mathrm{N}: \mathrm{P}: \mathrm{K}=1.8: 2.8: 1)$ and much lower viscosity $(<1800 \mathrm{cP})$ than dewatered digested biosolids and, reportedly, can be stored for over a year with no pathogen regrowth (Singh et al., 2006). Lystek has full-scale operations in Guelph ON, St. Marys ON, Peterborough ON and North Battleford, SK.

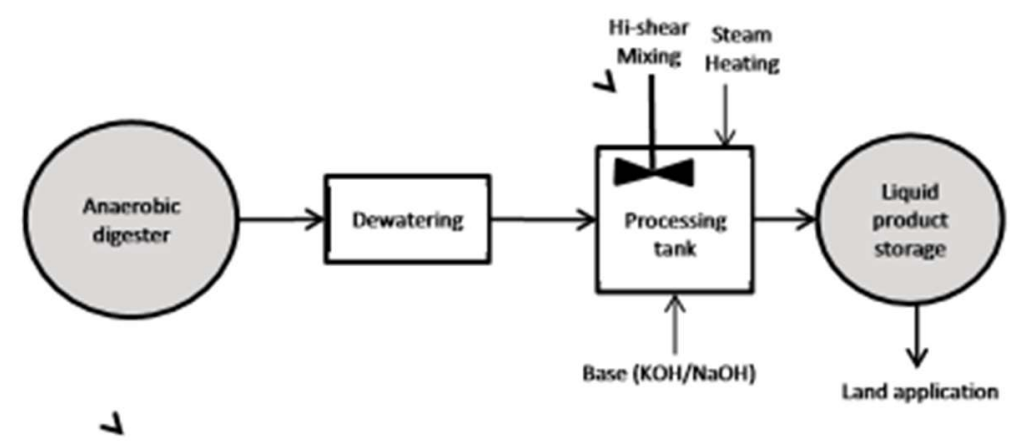

Figure 29: Schematic of the Lystek Process- Developed after Singh el al. 2006 and Janssens 2014

The N-Viro process, Figure 30 is high-solids, high-pH and large dose of alkalinity addition process. The process includes addition of cement kiln dust and lime to dewatered sludge followed by mixing, drying and heating. High temperature originates from chemical reactions of lime with water. Due to addition of $35-70 \%$ by dry weight of alkaline admixtures the end product has a physical structure similar to the soil. The process has been applied to primary, secondary and raw as well as digested sludges. Full-scale applications of this technology in Canada are located in Leamington, Sarnia, Thorold, ON, Halifax Region, NS, Banff, AB and Summerside, PEI (Hydromantis Inc., 2011). Large doses of lime/Kiln dust are necessary to achieve Class A biosolids product.

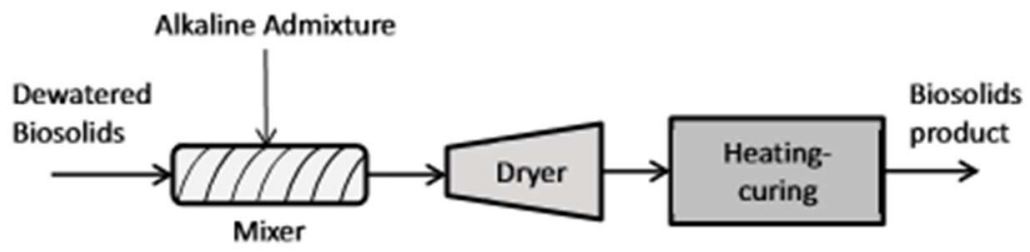

Figure 30: Schematic of an Established Process of Alkalinity Addition-the N-Viro Process (Federation of Canadian Municipalities and National Research Council, 2003) 
VitAG process is an emerging technology in which dewatered biosolids are converted to a commercial ammonium sulfate granular fertilizer for which there is a large existing market (Figure 31). The process is essentially a fertilizer manufacturing process where sludge stream serves the role of quenching the acid-ammonia reaction. The product has N:P:K:S ratio of 1620-16. The proponents claim that VitAG solution consumes almost $31 \%$ less energy and produce $40 \%$ less GHG compared to inorganic fertilizers while providing the same amount of plantavailable nitrogen (Gould et al., 2011).

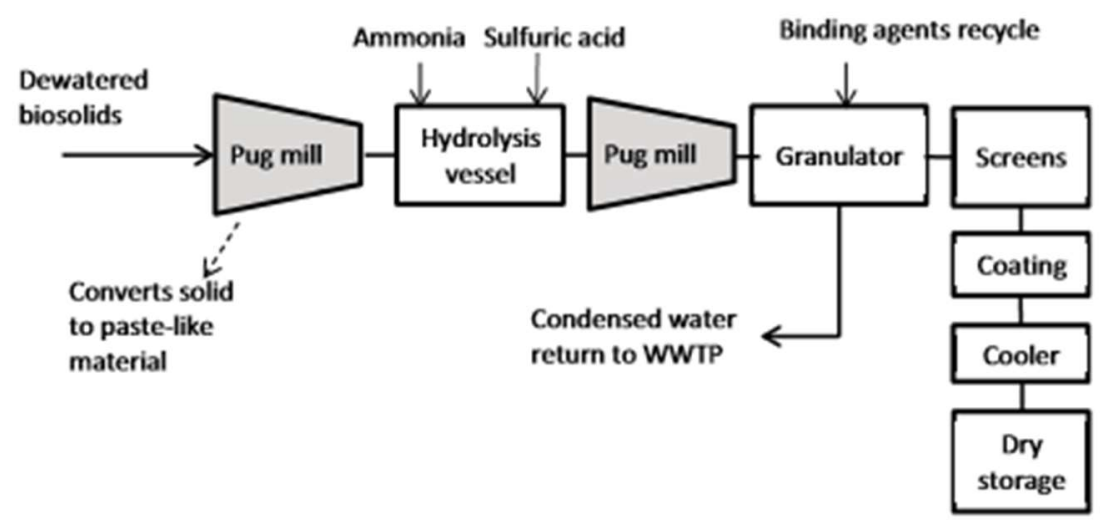

\section{Figure 31: An Emerging Technology: VitAG Process Producing Ammonium Sulfate - Developed After Gould et al -2011}

\subsubsection{Disinfection}

Disinfection is typically the last step in wastewater treatment processes. Disinfection is the process of destruction of pathogens that is important for the protection of the public health from waterborne disease transmission in drinking waters. The following techniques can be used for disinfection in WWTPs:

- Thermal disinfection: Boiling of wastewater for 15 to 20 min can eradicate pathogenic microorganisms but it is not practical technique for large-scale WWTPs.

- Chemical oxidants: Permanganate, hydrogen peroxide etc. can be used as chemical oxidants. However, some of the chemical oxidants are toxic and can produce harmful by-products.

- Chlorine: Chlorine gas or sodium hypochlorite solution can be used. There are certain drawbacks with chlorine disinfection, such as production of carcinogenic and harmful by-products known as chlorinated disinfection by-products (DBPs). 
- Ozone: Ozone is an effective disinfectant that has ability oxidize proteins and enzymes, thereby being effective against pathogens. When ozone decomposes in water, the free hydroxyl radicals are formed that have great oxidizing capacity. Ozonation is a more complex technology compared to chlorine or UV disinfection. Furthermore, require complicated equipment.

- UV disinfection: A highly efficient and environmentally-friendly (no chemical residual) technique for disinfection. UV radiation destroys the microbial cell's ability to reproduce. Fig 32.

- Electrochemical treatment: Rarely used and very expensive technology. (Elbeshbishy, 2016)

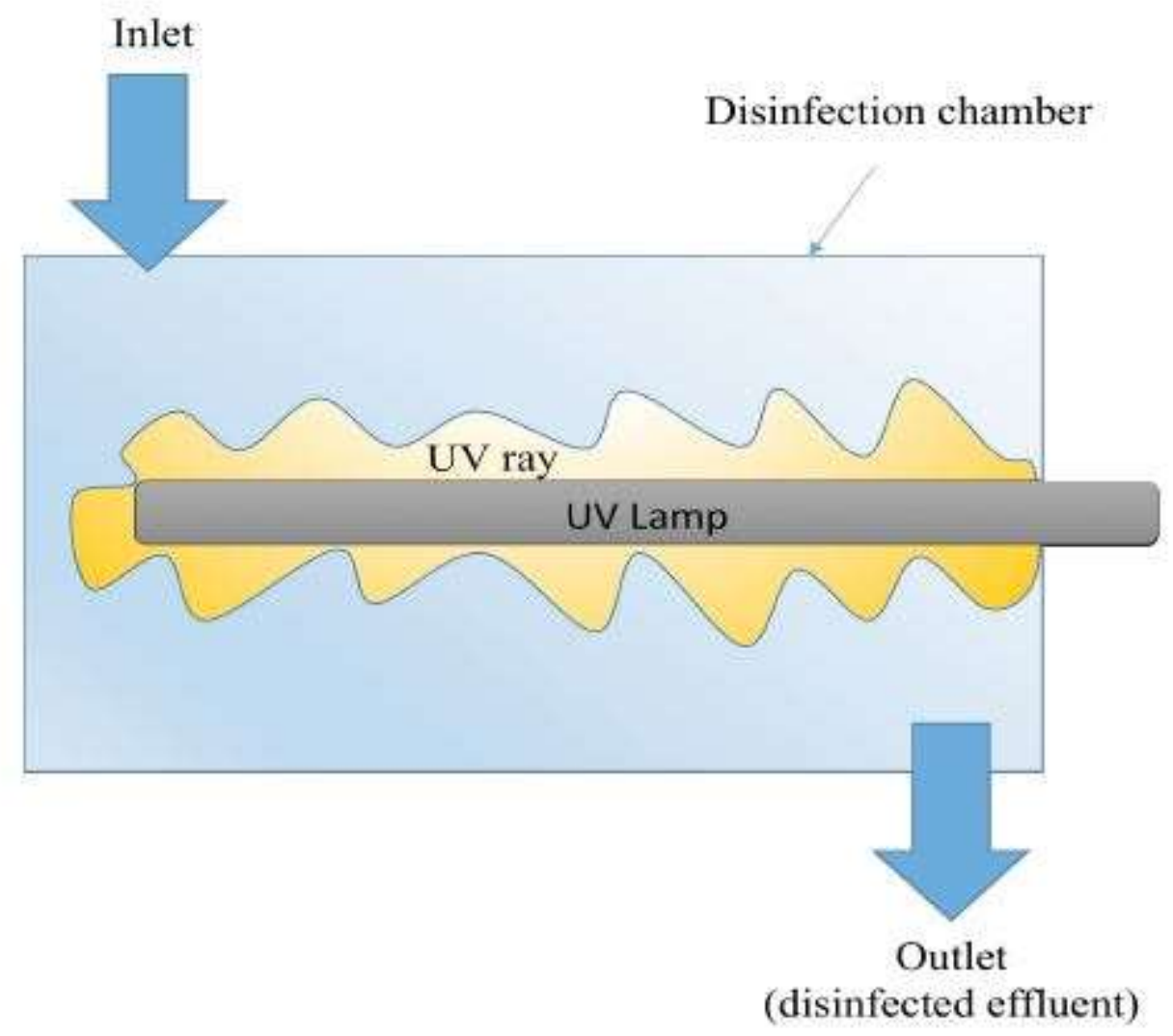

Figure 32: Schematic of a UV Disinfection Chamber (Elbeshbishy, 2016) 


\section{Optimization Opportunities Through Process Modifications}

\subsection{Plant Hydraulics}

Rapid changes in hydraulic load are caused by such things as intermittent pumped flows, the dormitory nature of the community, or combined sewage systems. Excessive variations in flow and load can affect the performance of the whole plant. These issues can be addressed by operational modifications such as:

- $\quad$ using a recycle system for variable flow control;

- $\quad$ using multiple smaller constant speed pumps;

- replacing the constant speed pumps with variable speed pumps or screw pumps;

- operation of the constant speed pumps in an influent pump station at a lower flow rate over a longer period of time;

- use of step feed and contact stabilization modes to alleviate the impact of excessive inflow and infiltration (I/I) on suspended growth treatment plants;

- returning digester supernatant or other concentrated streams during low flow periods;

- pump speed controllers and wet well level controllers set to minimize the number of pump starts and stops; and

- providing system storage and real-time control.

Inflow and infiltration (I/I) can be major sources of flow in wastewater systems. This impacts on system performance due to increased flow through the system and higher demand requirements from pumping stations. By implementing I/I reduction programs, wastewater flows requiring treatment can be significantly reduced resulting in lower treatment requirements and consequent resource (chemical and energy) savings.

\section{Screening}

Inadequate screening can limit plant performance and capacity, and greatly increase O\&M requirements. Although many small WWTPs still use manually cleaned screens, all plants should consider upgrading to automatically cleaned screens. Screen cleaning should be automated based on head loss and operating time. Adding bypass lines around screens for maintenance can also increase process flexibility.

\section{Grit Removal}

The installation of longitudinal or transverse baffles or modifying air-flow in aerated grit tanks can improve performance. If grit problems are occurring in a plant and the 
grit chamber appears to be adequately designed, the problem may be with the grit removal system. Components such as pumps, chain and flight conveyors, screw conveyors, or bucket elevators may be inadequately designed, installed, or maintained.

\subsection{Primary Treatment}

The following modifications should be considered to improve the process efficiency of primary treatment.

- Add coagulants to an undersized primary clarifier, or clarifier with high surface overflow rates (in excess of 40 to $60 \mathrm{~m} 3 / \mathrm{m} 2 . \mathrm{d}$ ).

- Relocate internal recycle or WAS flows.

- Improve flow splitting and control.

- Improve scum and sludge removal through automation.

\section{Reduce Chemical Usage}

Improving the feed rate control and mixing of chemicals at the point of addition will achieve reduced chemical use. There are many techniques and products available to improve chemical addition and mixing. Among others, they include in-line flash mixers or high velocity mixing systems. Jar tests should be performed on a routine basis to determine the optimum chemical dosage and dosing procedure.

High velocity mixing systems (HVMS) can be used to replace the injector, injector pump, diffuser, mechanical mixer, filter, and strainer of traditional induction systems. The HVMS operate with a propeller that injects the chemicals into the process stream at high velocities for better mixing. As a result of the better mixing achieved with HVMS, significant chemical use reduction can be achieved.

\section{Reduce Pre-Precipitation Chemicals for Phosphorus Removal}

Chemicals can be added for phosphorus removal at either the primary or secondary level of treatment. Generally, chemicals are more efficient for phosphorus removal when added to secondary treatment, and chemical use savings can be achieved. Chemicals may still be used in primary treatment to enhance biological nutrient removal (BOD5) removal in some facilities, reducing energy use in the biological system and secondary sludge production. Multi-point chemical addition results in the 
lowest chemical usage and sludge production when low effluent phosphorus concentrations must be achieved.

\subsection{Biological Treatment}

\section{Inadequate Process Flexibility}

If inadequate process flexibility is limiting the biological treatment process performance or capacity, piping and valving can be installed so aeration basins can be operated in the complete mix mode, the plug flow mode, the step feed mode, or the contact stabilization mode depending on flows, loads, and other critical conditions. Process equipment can be installed to increase process flexibility. This includes:

- the piping necessary to isolate individual tanks or processes;

- variable speed aerators or blowers in the aeration basin(s);

- variable speed sludge pumps for return and waste sludge flow; and

- chemical feed systems to improve settling characteristics.

\section{Nitrification}

Ammonia, chloramines, and chlorinated municipal effluents are considered to be toxic substances under the Canadian Environmental Protection Act (CEPA). Many new permits now include ammonia limits. Nitrification is the biological conversion of ammonia into nitrate. Alkalinity control is important in activated sludge systems designed for nitrification. If insufficient alkalinity is present during the conversion of ammonia to nitrate, the $\mathrm{pH}$ of the system drops, and nitrification may become inhibited. An adequate alkalinity adjustment system must be in place to provide a residual alkalinity of $50 \mathrm{mg} / \mathrm{L}$ for aeration and $150 \mathrm{mg} / \mathrm{L}$ for high-purity oxygen systems (EPA, 1982).

\section{Biological Nutrient Removal Processes}

BNR processes improve the nutrient removal capability of the WWTP and may also result in other benefits, such as improved sludge settlement, reduced sludge production, reduced process alkalinity consumption, and reduced process oxygen requirements. The potential reduction in plant capacity from implementing BNR needs to be considered. 
A wide variety of BNR process configurations are available. The process configuration selected must consider the effluent limits to be achieved and the current configuration of the bioreactors. It is also possible to create the required anaerobic and/or anoxic zones by installing baffles in the existing tankage if sufficient reactor volume and hydraulic gradient are available. Installation of mixing equipment and reconfiguration of aeration system and recycle pumping capabilities may be required depending on the BNR process selected.

\section{Oxygen Transfer System}

If a WWTP is experiencing inadequate oxygen transfer or if energy costs associated with the aeration system are to be minimized, methods of reducing the organic loading should be investigated before major modifications are made. Operational steps, such as cleaning diffusers or removing rag accumulation on surface mechanical aerators should also be pursued. If these measures do not improve the oxygen transfer capacity of the system, the following modifications can be considered.

- Install additional blowers to address an oxygen deficiency in a diffused aeration system if higher flow per diffuser is acceptable.

- Upgrade the diffused air system by replacing a mechanical system with a diffused air system, or replacing a low efficiency diffused aeration system with a higher efficiency system.

- Upgrade the mechanical aerator by refurbishing the old aerator cones, modifying aerator submergence, and operating all aerators at a higher rotational speed.

- Rearrange the aerator or diffuser spacing to remove dead zones and improve mixing.

- Increase the horsepower of existing blowers or mechanical aerators.

- Install baffles or mechanical mixing devices to improve basin mixing.

- Install/check air filters on the intake side of blowers.

- Supplement aeration systems with additional diffusers, or by alternative means.

- Inspect/maintain/repair the diffusers and delivery piping. 
- If the existing system must be upgraded or replaced as part of the plant upgrade, the following list outlines the best practice to upgrade an existing oxygen transfer system.

- Examine the condition of the existing oxygen transfer system.

- Determine the efficiency of the existing system through oxygen transfer testing.

- Calculate an estimate of existing system capacity, based on the efficiency of the existing system.

- Estimate the efficiency of alternative oxygen transfer systems.

- Determine whether evaluation of upgrade alternatives is necessary and desirable.

- Evaluate alternatives and select the most desirable alternative.

- Evaluate options for implementing the selected alternative.

- Implement oxygen transfer system improvements.

- Install an automatic dissolved oxygen system to vary air input according to the basin dissolved oxygen level to reduce energy consumption.

\section{Cold Climate Operation}

Cold wastewater temperatures result in decreased microbial activity and lower treatment efficiencies. To prevent freezing problems and minimize the effect of cold temperatures on biological treatment efficiency, covers can be placed over open tanks, and an earthen berm can be constructed to insulate above-ground tanks. The principles discussed for optimization in this best practice are applicable to WWTPs in any climatic condition.

\subsection{Secondary Clarifiers}

\section{Clarifier Modifications}

Modifications that have proven effective in improving the performance and capacity of clarifiers at existing wastewater treatment plants include the following (Daigger and Buttz, 1992).

- Influent flow splitting can be implemented when the full capacity of existing clarification units is not used due to an unequal and uncontrolled flow split. Several techniques are available, including flow splitting using multiple weirs, 
or orifices with a flow meter and flow control valve on the influent to each treatment unit. Hydraulic analysis is required to verify that adequate head is available and to design an effective system.

- Rapid flow variations are generated when a constant speed pump either turns on or turns off. Variable speed pumping can be implemented to smooth out and control flow variations. One method of variable speed pumping is to provide adjustable speed pumps with the number of pumps and their speed determined by fluid level in an upstream wet well. Constant speed pumps can also be coupled with recycle of pumped flow in excess of the influent flow back to the pump wet well. It is noted that implementation of a variable speed pumping system can increase the mechanical complexity of the plant and result in increased O\&M costs.

- An appropriately sized flocwell can be included in the clarifier to minimize the occurrence of dispersed suspended solids in the effluent.

- Inlet baffles can be used to dissipate energy contained in the influent flow, and to distribute flow for uniform entry into the clarifier. For circular clarifiers, a ring baffle supported off the sludge collection mechanisms has also proven useful in dissipating inlet energy and disrupting the density current. Outlet baffles are useful to direct high solids streams away from the clarifier effluent withdrawal point. Two types of effluent baffles are commonly used: McKinney baffle, which is horizontal in orientation and located just below the effluent weir, and the Stamford baffle, which is oriented at a 45 degree angle and is generally placed lower on the clarifier sidewall.

- Tube or plate settlers act as shallow clarifiers and improve the performance of existing clarifiers by increasing the effective area for clarification. The hydraulic flow pattern within the clarifier can also be partially modified to improve performance. Tube settlers are not effective for sludge thickening.

- Separate WAS and RAS pumps with flow meters provide the flexibility to optimize each function.

- Polymer can be added to enhance settling characteristics of sludge.

- Implementation of rapid sludge withdrawal systems can reduce sludge blanket levels in clarifiers, preventing blanket washout at high flows. 
- If the ability of sludge to settle is a cause of reduced clarifier capacity, the implementation of a selector zone to enhance settlement should be considered.

- Before adding clarifiers at high capital cost, these optimization measures should be thoroughly investigated.

Wahlberg (1998) has developed a protocol that can be used to optimize clarifiers.

\section{Excessive Clarifier Hydraulic Currents}

Dye testing can be used to identify excessive hydraulic currents. Modifications used to correct hydraulic current problems include inlet modifications to achieve both horizontal and vertical distribution of the incoming flow across the entire crosssectional area, while minimizing short circuiting and turbulence by the addition of inlet or outlet baffles, or weir relocation/addition and blanking off corner weirs. If short circuiting or a sludge density current is observed, baffling should be provided to prevent short circuiting and poor solids removal. Baffles and flow deflectors can also provide equal flow distribution across the width of the clarifier.

\section{Sludge Bulking Control}

A common misconception associated with the performance of clarifiers in a suspended growth system is that solids loss is the result of a clarifier failure, when, in fact, it is often due to poor sludge settling characteristics. The presence of excessive quantities of filamentous micro-organisms can cause a poorly settled biomass. By improving the settling characteristics of the sludge, the mixed liquor suspended solids (MLSS) concentration that can be maintained in the system is increased, which allows an increase in the organic loading on the system, resulting in the opportunity to increase plant capacity without increasing the basin volume. For a nitrifying system, an increased MLSS concentration allows nitrification to be accomplished at shorter HRTs. Alternatively, higher hydraulic loadings can be applied to the secondary clarifiers. Several sludge bulking control measures are available including:

- chlorinating the return activated sludge or mixed liquor in the reactor;

- modification of the environmental conditions (e.g., addition of nutrients, including nitrogen, phosphorus, and dissolved oxygen); 
- introduction of an organic loading gradient through addition of a selector to the suspended growth system;

- implement selective wasting to remove foam/scum-causing microorganisms from the system;

- remove impediments to the free passage of foam/scum through the bioreactor/ secondary clarifier system to a point where the foam/scum can be eliminated from the system; and

- discontinue the practice of co-settling of waste activated sludge in the primary treatment system.

Microscopic examinations should be performed routinely to monitor biomass for sludge bulking due to filamentous organisms. The methods are described in Manual on the Causes and Control of Activated Sludge Bulking, Foaming, and Other Solids Separations Problems (Lewis Publishers, 2003) and in Dynamic Corporation (USEPA, 1987), along with options to control sludge bulking.

\section{Inadequate Return Sludge and Waste Sludge Flexibility}

According to Assessment of Factors Affecting the Performance of Ontario Sewage Treatment Facilities (XCG, 1992), the lack of instrumentation to measure return sludge and waste sludge flow rates was the most serious limitation at small WWTPs with air lift sludge return systems. Without the knowledge of these flow rates, it is difficult to adjust for changes in flow or settling characteristics, or to control solids inventory in the plant. 


\section{Design Criteria \& Equations}

This section summarises the design criteria for various units and their ranges for each step along with the equations used for design calculations.

\subsection{Characteristics of Screenings}

Quantity: Typically, 20L/10 $\mathrm{m}^{3}$ of wastewater treated

Coarse: $70-95 \%$ volatile, dry solids content of 10 to $20 \%$, density $640-960 \mathrm{~kg} / \mathrm{m}^{3}$, $3.5-35$

$\mathrm{L} / 10 \mathrm{~m} 3$ (sep. sewer), 3.5 - 84 (combined sewer), peaking factor $\left(\mathrm{Q}_{\mathrm{p}} / \mathrm{Q}_{\text {ave }}\right)-5$ for separate and 20 for combined

Fine screening: volatile fraction $=65-95 \%$, density is lower than coarse, moisture content

Table 6: Coarse screenings characteristics (Droste, 1997)

\begin{tabular}{|l|l|}
\hline Item & Range \\
\hline Average from separate sewer system & $3.5-35 \mathrm{~L} / 1000 \mathrm{~m} 3$ \\
\hline Average from combined sewer system & $3.5-84 \mathrm{~L} / 1000 \mathrm{~m} 3$ \\
\hline Solids content & $10-20 \%$ \\
\hline Bulk density & $640-1100 \mathrm{~kg} / \mathrm{m} 3$ \\
\hline Volatile content of solids & $70-95 \%$ \\
\hline Fuel value & $(5400 \mathrm{BTU} / \mathrm{lb})$ \\
\hline
\end{tabular}

Approach velocity of wastewater through the channel (vc):

Where,

$$
v_{c}=\frac{Q}{A_{c}}=\frac{Q}{W \times d}
$$

$\mathrm{Q}=$ Design flow rate, $\mathrm{m} 3 / \mathrm{s}$

$\mathrm{Ac}=$ Cross section area of the channel, $\mathrm{m} 2$

$\mathrm{W}=$ Channel width, $\mathrm{m}$

$\mathrm{d}=$ Depth of water in the channel, $\mathrm{m}$

**Usually, rectangular channels are used: $(d / w=1.5)$ to give the most

efficient section 
Velocity of wastewater through the screen (vs, $\mathrm{m} / \mathrm{s})$ can be estimated using the following equation,

$v \mathrm{~s}=Q / A \mathrm{~s}$

Where: $\mathrm{Q}=$ Design flow rate, $\mathrm{m} 3 / \mathrm{s}$

As $=$ Available vertical cross section area of the screen, $\mathrm{m} 2$

As $=(\mathrm{N}-1) \times \mathrm{S} \times \mathrm{d}$

Where: $\mathrm{N}=$ number of bars

$\mathrm{S}=$ opening space between bars, $\mathrm{m}$

\section{Head loss through the screen $(\mathrm{hL})$ :}

$$
h_{L}=\frac{1}{C_{d}}\left(\frac{v_{s}^{2}-v_{c}^{2}}{2 g}\right)
$$

Where,

$\mathrm{hL}=$ Head loss through the screen, $\mathrm{m}$

$=\mathrm{h} 1-\mathrm{h} 2=$ upstream depth of flow - downstream depth of flow $\rightarrow$ should not exceed $\mathbf{0 . 1 5} \mathbf{m}$

$\mathrm{Cd}=$ Coefficient of discharge, usually

$\mathrm{Cd}=0.7-0.84$ for a clean screen $\mathrm{Cd}=0.6$ for clogged screen

$\mathrm{vs}=$ Velocity of flow through the opening of the bar screen, $\mathrm{m} / \mathrm{s}$

$\mathrm{vc}=$ approach velocity of wastewater in the channel

$\mathrm{g}=$ acceleration of gravity, $9.81 \mathrm{~m} / \mathrm{s} 2$

Table 7: Summary of bar screen design criteria

\begin{tabular}{|l|l|}
\hline Design Parameter & Typical/Recommended \\
\hline Peaking factor & $2-3$ \\
\hline Head loss (maximum) & $0.15 \mathrm{~m}$ \\
\hline $\begin{array}{l}\text { Minimum approach velocity in upstream } \\
\text { channel, m/s }\end{array}$ & 0.45 \\
\hline $\begin{array}{l}\text { Maximum velocity of flow through the } \\
\text { opening of the bar screen, } \mathrm{m} / \mathrm{s}\end{array}$ & 0.9 \\
\hline
\end{tabular}


Table 8: Design factors for manually and mechanically cleaned bar racks

\begin{tabular}{|l|l|l|}
\hline Design Factor & Manually cleaned & Mechanically cleaned \\
\hline $\begin{array}{l}\text { Velocity / through rack } \\
(\mathrm{mm} / \mathrm{s})\end{array}$ & $0.3-0.6$ & $0.6-1.0$ \\
\hline Bar size- Width (mm) & $4-8$ & $8-10$ \\
\hline Bar size- Depth (mm) & $25-50$ & $50-75$ \\
\hline $\begin{array}{l}\text { Clear spacing between bars } \\
(\mathrm{mm})\end{array}$ & $25-75$ & $10-50$ \\
\hline $\begin{array}{l}\text { Allowable head to loss } \\
(\mathrm{mm})\end{array}$ & $150-800$ & $150-800$ \\
\hline $\begin{array}{l}\text { Slope from horizontal } \\
(\text { degrees) }\end{array}$ & $45-60$ & $75-85$ \\
\hline
\end{tabular}

\subsection{Typical Design Criteria for Aerated Grit Chamber are:}

-Detention time of 2-5 minutes (Typical $3 \mathrm{~min}$ ) at peak flow rates.

- Minimum two (2) channels in parallel for continuous operation

- Typical width to depth ratio is $1: 1-5: 1$ (Typical 1.5:1)

- Length to width ratio is $3: 1-5: 1$ (Typical 4:1)

- Air supply range from $0.2-0.5 \mathrm{~m} 3 / \mathrm{min}$ per $\mathrm{m}$ of length

- Depth: 2 to $5 \mathrm{~m}$

- Length: 7.5 to $20 \mathrm{~m}$

- Width: 2.5 to $7.0 \mathrm{~m}$

- Minimum two (2) channels in parallel for continuous operation

- Grit quantities range from 0.004-0.02 m3/103 m3 (0.015 m3/103 m3 typical)

- Surface overflow rate should be less $(0.01-0.02 \mathrm{~m} / \mathrm{s})$ than settling velocity of grit $0.02-0.03 \mathrm{~m} / \mathrm{s}$

*Surface overflow rate represents flow rate per unit surface area

Surface overflow rate $(\mathrm{m} / \mathrm{s})=$ Flow rate $(\mathrm{Q}) /$ surface area of chamber $(\mathrm{A})$

$=$ Flow rate $/($ width $\times$ length $)$ 


\subsection{Design Criteria and Equations-Primary Settling}

- Primary settlers are typically designed on the basis of detention time, overflow rate, and weir loading rate

- Detention time $=$ Volume of tank $/$ Flow rate $=\mathrm{V} / \mathrm{Q}$

- Surface overflow rate $=$ Flow rate $/$ Settling surface area $=Q / A$

- Weir loading rate=Flow rate/weir length

- Design criteria are specified on the basis of average flows and peak flows. Both need to be satisfied.

Table 9: Design Criteria Typically Used for Primary Settling Tank.

\begin{tabular}{|l|l|l|}
\hline & Range & Typical/Recommended \\
\hline Detention time, hr & $1.5-2.5$ & 2 \\
\hline $\begin{array}{l}\text { Surface overflow rate, } \\
\text { m3/m2-d-- At average flow }\end{array}$ & $30-50$ & 40 \\
\hline $\begin{array}{l}\text { Surface overflow rate, } \\
\text { m3/m2-d-- At peak flow }\end{array}$ & $70-130$ & 100 \\
\hline Weir loading rate, m3/m-d & $125-500$ & 260 \\
\hline Rectangular tank & $15-90$ & $25-40$ \\
\hline Length, m & $3-24$ & $5-10$ \\
\hline Width, m & $3-5$ & 4.5 \\
\hline Depth, m & $1-7.5$ & 4 \\
\hline Length to width ratio & $4.2-25$ & $7-18$ \\
\hline Length to depth ratio & $3-60$ & \multicolumn{2}{|l|}{} \\
\hline Circular tank & $3-5$ & 4.5 \\
\hline Diameter, m & \multicolumn{2}{|l|}{} \\
\hline Depth, m & \multicolumn{2}{|l|}{} \\
\hline
\end{tabular}




\subsection{Design Criteria and Equations-Secondary Treatment (General) (Elbeshbishy, 2016)}

Volumetric Loading Rate

Volumetric loading rate is one of the major design and operating parameters for biological engineered systems (i.e., wastewater treatment plant). Volumetric loading rate is expressed as the mass load of a compound (e.g., substrate) per unit volume per unit time.

$$
V_{L}=\frac{Q S_{O}}{V}
$$

Where, $\mathrm{VL}=$ Volumetric loading rate, $\mathrm{kg} / \mathrm{m} 3-\mathrm{d}$

So $=$ Substrate concentration entering the reactor, $\mathrm{kg} \mathrm{BOD} / \mathrm{m} 3$

$\mathrm{V}=$ Volume of bioreactor, $\mathrm{m} 3$

$\mathrm{Q}=$ Flow rate, $\mathrm{m} 3 / \mathrm{d}$

Solid and Hydraulic Residence Time

Selection of residence time of wastewater in the bioreactor (i.e., activated sludge process) is very important, since it determine the volume of the bioreactor. Residence time is selected primarily based on the characteristics of wastewater, mass loading rate and microbial biodegradation kinetics.

Typically, two residence times used for biological treatment processes:

solid residence time (SRT) and hydraulic residence time (HRT). HRT indicates the average time the wastewater remains in the bioreactor in contact with the microorganisms; while SRT indicates the time that biomass (solids) remains in the reactor to achieve a given degree of treatment. 
For continuous stirred tank reactor (CSTR),

$$
\text { HRT, } \theta=\frac{\text { Volume of Reactor }(V)}{\text { Influent flow rate }(Q)}
$$

Where, $\mathrm{V}$ is the volume of the bioreactor $\left(\mathrm{m}^{3}\right)$, and $\mathrm{Q}$ is the influent flow rate $\left(\mathrm{m}^{3} / \mathrm{d}\right)$. Thus, HRT is the average length of time that the soluble compounds remain in a bioreactor

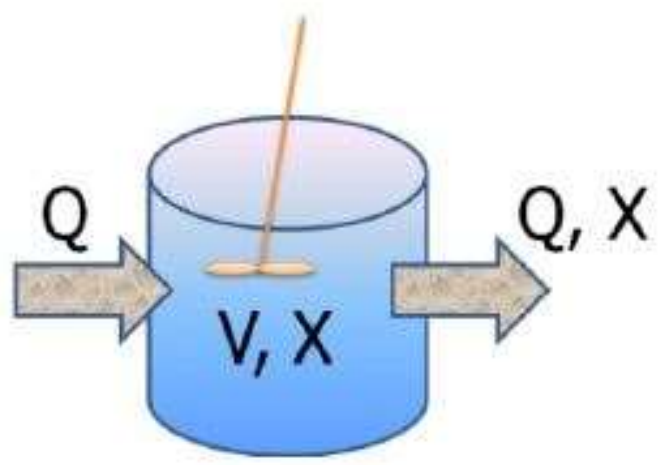

Figure 33: CSTR (Elbeshbishy, 2016)

SRT is the average time that the particulate matter (e.g., cell biomass) stays in the bioreactor (also known as sludge age or mean cell residence time). The SRT can be expressed using the following equation:

$$
\text { SRT, } \theta_{\mathrm{c}}=\frac{\text { Mass of solids in the bioreactor }(\mathrm{kg})}{\text { Solid wastage rate }(\mathrm{kg} / \mathrm{d})}
$$

Now, we will calculate SRT for bioreactors with and without effluent recycle. First, let's consider a CSTR shown in Figure 8 where suspended solids concentrations in the reactor and effluent are same $(X \mathrm{mg} / \mathrm{L})$. The SRT of the system can be calculated from the following equation.

$$
\text { SRT, } \theta_{\mathrm{c}}=\frac{\text { Mass of biomass in the bioreactor }}{\text { Biomass discharge rate }}=\frac{V X}{Q X}=\frac{V}{Q}=\text { HRT }
$$




\subsection{Conventional Activated Sludge Process}

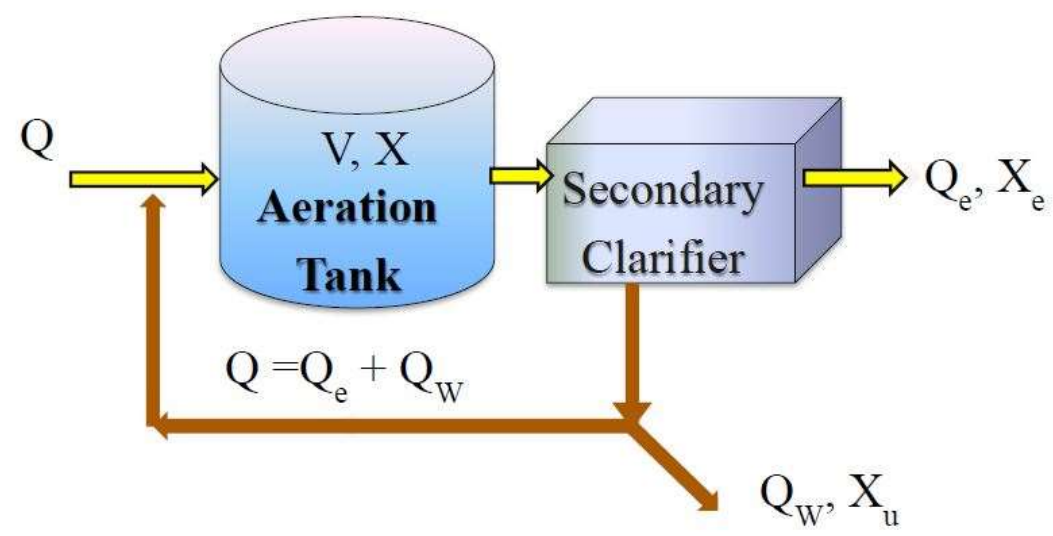

Figure 34: Activated Sludge Process (Elbeshbishy, 2016)

SRT, $\theta_{\mathrm{c}}=\frac{\text { Total Mass of biomass in the bioreactor }}{\text { Biomass discharge rate }}=\frac{V X}{\text { Solid discharge rate }}$

In AS process, solids are discharged from two points: (1) wastewater effluent and (2) wasting settled sludge from the bottom of the clarifier, as described in Figure 29. Therefore, the total biomass discharge rate would be the summation of biomass (solids) discharge rate for effluent and clarifier (QwXw $+\mathrm{QeXe})$. Thus, SRT for AS process can be expressed as following,

$$
\text { SRT, } \theta_{\mathrm{c}}=\frac{V X}{Q_{e} X_{e}+Q_{w} X_{u}}
$$

Where, $Q=$ Influent wastewater flow rate $(\mathrm{m} 3 / \mathrm{d})$

$\mathrm{Qe}=$ Effluent wastewater flow rate $(\mathrm{m} 3 / \mathrm{d})$

$\mathrm{Qw}=$ Biomass wasting rate $(\mathrm{m} 3 / \mathrm{d})$

$\mathrm{V}=$ Volume of aeration tank (m3)

$\mathrm{X}=$ Concentration of biomass in the aeration tank $(\mathrm{mg} / \mathrm{m} 3)$

$\mathrm{Xe}=$ Concentration of biomass in the effluent $(\mathrm{mg} / \mathrm{m} 3)$

$\mathrm{Xu}=$ Concentration of biomass in the wasted sludge $(\mathrm{mg} / \mathrm{m} 3)$ 
The required SRT and HRT depend on the characteristics of the wastewater to be treated. For biodegradable wastewater (containing high BOD), bioreactor can be operated at shorter HRT. However, at very short SRT, microbes can wash out from the bioreactor, while increasing SRT and HRT will increase the reactor volume as well as the capital cost. For completely mixed system with no recycle, SRT is equal to the HRT, while with recycle, SRT is significantly different from HRT. SRT and HRT have been decoupled in some bioprocesses such as activated sludge system, and membrane bioreactors to maintain shorter HRT and relatively longer SRT at the same time.

When SRT is too high, sludge 'bulking' due to growth of filamentous bacteria $\rightarrow$ Sludge does not settle well $\rightarrow$ high Xe

When SRT is too short, pin floc $\rightarrow$ Sludge does not settle well

Typical SRT and HRT for AS process used in municipal wastewater treatment are 3-15 $\mathrm{d}$ and 4-8 h.

\section{Mixed liquor suspended solids (MLSS)}

Typical MLSS in aeration tank range from 2000 to $4000 \mathrm{mg} / \mathrm{L}$. Actual MLSS include inorganic inert solids, active biomass, cell debris (decay products) and nbVSS (from influent WW) that are considered in advanced models. We will consider that the mixed liquor volatile suspended solids (MLVSS) mainly represent the heterotrophic cell biomass.

Mixed liquor suspended solids (MLSS), TSS

$=$ Mixed liquor volatile suspended solids (MLVSS)+ Inorganic inert

$=($ Heterotrophic cell biomass + cell debris + nbVSS from influent $)+$ Inorganic Inert

\section{Food to Microorganism (F/M) Ratio}

The food to microorganism $(\mathrm{F} / \mathrm{M})$ ratio is one of the significant design and operational parameters used in activated sludge systems. A balance between substrate consumption and biomass generation helps in achieving system equilibrium 
$\frac{\mathrm{F}}{\mathrm{M}}=\frac{\mathrm{Q}\left(\mathrm{S}_{\mathrm{O}}-\mathrm{S}\right)}{\mathrm{VX}}=\frac{\text { Mass of substrate }}{\text { Mass of biomass }}$

Where, $\mathrm{F} / \mathrm{M}=$ food to microorganism ratio, $\mathrm{mg} \mathrm{BOD} / \mathrm{mg}$ VSS-d

$\mathrm{V}=$ Volume of bioreactor, $\mathrm{m} 3$

So, $\mathrm{S}=\mathrm{BOD}$ of substrate in influent and effluent, respectively, $\mathrm{mg} / \mathrm{L}$

$\mathrm{X}=$ MLSS concentration in the reactor, $\mathrm{mg} / \mathrm{L}$

- Please note that different book use different formula for $\mathrm{F} / \mathrm{M}$ ratio based on different assumptions.

-Conventional activated sludge system, $0.2<\mathrm{F} / \mathrm{M}<0.5$

- The use of SRT and F/M ratio in design allows for trade-off between reactor volume and MLSS concentration in the reactor.

The oxygen requirement can be calculated using the following equation:

$M o 2=B O D$ removed - COD of waste sludge

$$
=Q\left(S_{o}-S\right)-1.42 P_{X, \text { biomass }}
$$

Where,

$\mathrm{Q}=\mathrm{WW}$ flow rate, $\mathrm{m} 3 / \mathrm{d}$

So, $\mathrm{S}=\mathrm{BOD}$ of substrate in influent and effluent, respectively, $\mathrm{kg} / \mathrm{m} 3$

$\mathrm{Mo} 2$ = oxygen requirement for BOD removal, $\mathrm{kg} \mathrm{O} 2 / \mathrm{d}$

$\mathrm{P}_{\mathrm{X}, \text { biomass }}=\mathrm{P}_{\mathrm{X}, \text { VSS }}-\mathrm{P}_{\mathrm{nbVSS}(\text { influent })}=$ Biomass wasted, $\mathrm{kg} \mathrm{VSS} / \mathrm{d}$

$1.42=\mathrm{COD}$ of cell tissue, $\mathrm{g}$ COD/g VSS

- $1.42 \times P x$, biomass is subtracted, since it represents the portion of substrate that gets converted to biomass and then removed from the system before it exerts its oxygen demand. 
The oxygen requirement for only BOD removal will vary from 0.9 to $1.3 \mathrm{~kg} \mathrm{O} 2 / \mathrm{kg}$ BOD for SRTs of 5 to $20 \mathrm{~d}$, respectively. Typical volumetric air supply rate is 30$60 \mathrm{~m} 3 \mathrm{air} / \mathrm{kg}$ BOD5

Oxygen uptake rate (OUR) can be defined as the oxygen required per unit volume of aeration tank, OUR=MO2/V

For conventional AS process, OUR is typically $30 \mathrm{mg} / \mathrm{L}-\mathrm{h}$. 


\section{Design Calculations with Primary Sedimentation}

- The design of treatment plant for medium sized city with population of 100,000 , design period of 30 years, and the growth rate is assumed to be about $0.75 \%$ per year.

- Assume that wastewater return be $90 \%$ of the water supply. The $10 \%$ is lost as irrigation or other losses.

- Based on the Ontario wastewater standards for Region of Waterloo, the per capita consumption is assumed to be 350 lit/day.

Peak factor Harmon formula

$\mathrm{M}=1+14 /(4+$ sqrt $\mathrm{P})$

The value of $\mathrm{M}$ is between $2 \& 5$

Where "P" is population in thousands

The calculations for future population based on the fact that growth rate are $0.75 \%$ and time is 30 years.

The design Population $=100,000+0.75 * 30 * 100,000 / 100$

$$
=122,500
$$

The average water use $=122,500 * 350$

$$
\text { = 42,875 Cubic Meter Per Day }
$$

Peak Factor $(\mathrm{M})=1+14 /(4+$ sqrt $\mathrm{P})$

$$
\mathrm{M}=1.9
$$

As the value of $M$ lies between $2 \& 5$, we assume $M$ to be 2 .

Peak Flow $=2 * 42,875$ Cubic Meter Per Day

$$
=85,750 \text { Cubic Meter Per Day }
$$

The returned wastewater $=90 \%$ of the demand

$$
=0.9 * 42,875
$$

Average Daily Flow $\quad=38,587$ Cubic Meter Per Day 
Peak Daily Flow

Peak Daily Flow
$=0.9 * 85,750$

$=77,175$ Cubic Meter Per Day

\subsection{Sizing of Equalization Tank}

The sizing of the equalization tank can be for the average flow and the holding period of 4 hours. The justification is that the hourly flows vary from season to season and are highly variable for certain days of the week and it is time consuming to measure such hourly variation for the community.

The size of Equalization tank $=38,587 / 6=6,431.1$ Cubic Meter.

Let the depth be $5 \mathrm{~m}$ and free board of $0.8 \mathrm{~m}$,

The width to length ratio be $1: 2$

The area of tank $=1,287 \mathrm{Sqm}$

The length of Tank= 52 Meter

The width of Tank=26 Meter

\section{Size of Equalization Tank $=5.8 * 26 * 52$ (All Dimensions in Meters)}

\subsection{Design Calculations for Screens}

The assumption that velocity through the screen is $0.9 \mathrm{~m} / \mathrm{sec}$

Bar Spacing $=2.5 \mathrm{~cm}$

Provide 2 identical Screening Channels with mechanical Cleaning Device and angle 70 Degree.

The max flow is 8.93 Cubic Meter/sec

The average flow is 4.46 Cubic Meter/sec 


\subsection{Design of Screening Channel}

Assume the depth of flow in Screening Channel $=1.5 \mathrm{~m}$

Net area of flow $=$ Qav/Velocity

$$
\begin{aligned}
& =4.46 / .9 \\
& =4.96 \mathrm{Sqm}
\end{aligned}
$$

Clear Width of Screening Channel=4.95/depth

$$
\begin{aligned}
& =4.95 / 1.5 \\
& =3.3 \mathrm{~m}
\end{aligned}
$$

Assume the width of bar be $10 \mathrm{~mm}$

Number of Spacing $=3300 / 25 \mathrm{~mm}$

$$
=132 \text { Spacings }
$$

Number of bars $=131$

The width blocked by bars $=131 * 10 / 1000$

$$
=1.31 \mathrm{~m}
$$

The width of Screening Channel=1.31+3.3

$$
=4.61 \mathrm{~m}
$$

Screening Channel size $1.5 \mathrm{~m} * 4.61 \mathrm{~m} * 20 \mathrm{~m}$

\subsection{Design Calculation for Aerated Grit Chamber}

Provide four identical Grit Chambers

Maximum Flow through each grit chamber $=8.93 / 4$

$=2.23$ Cubic Meter/ Sec

Volume of each chamber for 4 minutes detention period

$=2.23 * 4 * 60$

$=535.2$ Cubic Meter

Provide Average Depth=4.5 Meter 
Free Board $=0.8 \mathrm{M}$

Total Depth $=4.5+.8$

$$
=5.3 \text { Meter }
$$

Surface Area of Channel=535.2/5.3

$$
=100.98 \mathrm{Sqm}
$$

Provide ratio of length : width $=4: 1$

Width $=\operatorname{Sqrt}(100.98 / 4)$

$$
=5 \mathrm{~m}
$$

Length $=20 \mathrm{~m}$

Final Dimension $=5.3 * 5 \mathrm{M} * 20 \mathrm{M}$ and four numbers.

Selection of Diffuser-

The diffusers are to be placed along the centreline of the length of the chamber at $0.5 \mathrm{~m}$ above the bottom.

The air supply requirements are $7.8 \mathrm{lit} / \mathrm{sec}$ per meter length of Chamber.

Theoretical air requirement per chamber $=7.8 * 20$

$$
=156 \mathrm{Lit} / \mathrm{sec}
$$

Provide $150 \%$ above the net requirement

The aerator to be having capacity of $156^{*} 1.5=234 \mathrm{Lit} / \mathrm{sec}$ Per chamber

The total capacity of aerator $=936 \mathrm{lit} / \mathrm{sec}$

\subsection{Design of Primary Sedimentation Tank}

\section{Design Parameters-}

We shall use four rectangular primary sedimentation tanks.

Overflow rate and detention time is based on average flow of 4.46 Cubic Meter Per day The overflow rate shall be less than 36 Cubic Meter/Sqm/ Day

Detention time shall not be less than 1.5 hours and shall not be more than 2.5 hours.

The weir loading shall be less than 186 Cubic Meter/meter/day at average flow 
The depth shall not be less than $2 \mathrm{~m}$

Inflow $\mathrm{BOD}(5)=54 \mathrm{gm} /$ person-day= $171.2 \mathrm{mg} / \mathrm{lit}$

$\mathrm{BOD}($ Ultimate $)=1.47 * \mathrm{BOD}(5)=252 \mathrm{mg} / \mathrm{lit}$

Design Calculations-

Average flow for each sedimentation tank=4.46/4=1.115 Cubic Meter/sec

Overflow Rate $=36$ Cubic Meter/Sqm-Day

Surface Area of each tank $=1.115 * 86400 / 36$

$$
=2676 \mathrm{Sqm}
$$

Assume Width : Length $=1: 4$

Width $=\operatorname{Sqrt}(2676 / 4)$

$$
=25 \mathrm{M}
$$

Length $=4 * 25$

$$
=100 \mathrm{M}
$$

Provide Depth $3.5 \mathrm{M}$

Total Depth $=3.5$ meter

Check Overflow rate

$=1.115 * 86400 / 25 * 100$

$=38.5$ which is more than 36 .

Hence revise the dimension to $26 \mathrm{M} * 106 \mathrm{M}$

Check Overflow Rate

$=1.115 * 86400 / 26 * 104$

$=35.62$ Which is less than 36 Cubic Meter/Sqm- Day

Detention Time Calculations

Volume of the Sedimentation Tank $=26 * 106 * 3.5$

$$
\text { =9646 Cubic Meter }
$$

Detention Time $=$ Volume of Tank/Flow

$=9646 / 1.15$ 


$$
\begin{aligned}
& =8387 \mathrm{sec} \\
& =2.32 \text { Hours }
\end{aligned}
$$

Detention time shall be between 1.5 Hours \& 2.5 Hours.

\subsection{Design of Activated Sludge System}

Design of Completely Mixed Activated Sludge System

Wastewater Flow(Average)

$\mathrm{BOD}_{5} 54 \mathrm{~g} /$ person-day

BOD Ultimate $\left(1.47 * \mathrm{BOD}_{5}\right)$

Total kjeldahl nitrogen (TKN) ( 8 g/person-day)

Phosphorus ( 2 g/person-day)

Winter Temperature in Aeration Tank

Yield Coefficient " $Y$ "

Decay constant $K_{d}$

Specific substrate utilization rate

$$
\begin{aligned}
& =38,587 \mathrm{Cum} \text { Per Day } \\
& =0.447 \mathrm{Cum} \text { Per Sec } \\
& =171.43 \mathrm{mg} \text { Per Litre } \\
& =252 \mathrm{mg} \text { Per Litre } \\
& =25.4 \mathrm{mg} \text { Per Litre } \\
& =6.35 \mathrm{mg} \text { Per Litre } \\
& =18 \mathrm{Degree} \mathrm{Centigrade} \\
& =0.6 \\
& =0.07 \text { per day } \\
& =(0.038 \mathrm{mg} /)^{-1}(\mathrm{~h})^{-1} \text { at } 18^{\circ} \mathrm{C}
\end{aligned}
$$

Assume $30 \%$ raw $\mathrm{BOD}_{5}$ is removed in primary sedimentation

$\mathrm{BOD}_{5}$ going to aeration is

$=120 \mathrm{mg}$ Per Litre

Selection of $\theta_{c}, t$ and MLSS concentration:

Considering the operating temperature and the desire to have nitrification and good sludge settling characteristics, adopt $\theta_{c}=5 \mathrm{~d}$. As there is no special fear of toxic inflows, the HRT, $\mathrm{t}$ may be kept between 3-4 h, and MLSS $=4000 \mathrm{mg} / \mathrm{l}$. 
Effluent $\mathrm{BOD}_{5}$ :

Substrate concentration, $S=\underline{1}\left(1 / \theta_{c}+k_{d}\right)=$ qY $(1 / 5+0.07)$ $(0.038)(0.6)$

$\mathrm{S}=12 \mathrm{mg} / \mathrm{l}$

Assume suspended solids (SS) in effluent $\mathrm{VSS} / \mathrm{SS}$

$$
=20 \mathrm{mg} / 1
$$$$
=0.8 \text {. }
$$

If degradable fraction of volatile suspended solids (VSS) $\quad=0.7$ (check later) $\mathrm{BOD}_{5}$ of VSS in effluent $=0.7(0.8 \times 20)$ $=11 \mathrm{mg} / 1$. $=23 \mathrm{mg} / \mathrm{l}$ (acceptable).

Aeration Tank:

$\left.V X=\frac{Y Q \theta_{c}}{1+\mathrm{k}_{d} \theta_{c}}-\mathrm{S}\right)$ where $X=0.8(4000)=3200 \mathrm{mg} / \mathrm{l}$

or $3200 \mathrm{~V}=\underline{(0.6)(5)(38,587.5)(120-12)}$ $[1+(0.07)(5)]$

$\mathrm{V}=2,894.0 \mathrm{~m}^{3}$

Detention time, $\mathrm{t}=\frac{2,894.0 \times 24}{38,587}=1.8$ hours

$\mathrm{F} / \mathrm{M}=\underline{(120-12)(38,587)}=0.45 \mathrm{~kg} \mathrm{BOD}_{5}$ per $\mathrm{kg}$ MLSS per day (3200) $(2,894)$ 
Let the aeration tank be in the form of four square shaped compartments operated in two parallel rows, each with two cells measuring $14 \mathrm{~m} \times 14 \mathrm{~m} \times 4.0 \mathrm{~m}$

Return Sludge Pumping:

If suspended solids concentration of return flow is $1 \%=10,000 \mathrm{mg} / 1$

$\mathrm{R}=\frac{\mathrm{MLSS}}{(10000)-\mathrm{MLSS}}=0.67$

$\mathrm{Q}_{\mathrm{r}}=0.67 \times 38,587=25,853 \mathrm{~m}^{3} / \mathrm{d}$

Surplus Sludge Production: Net VSS produced $\mathrm{Q}_{\mathrm{w}} \mathrm{X}_{\mathrm{r}}=\underset{\theta_{\mathrm{c}}}{\mathrm{VX}}=\frac{(3200)(2894)}{(5)}\left(10^{3} / 10^{6}\right)=1852 \mathrm{~kg} / \mathrm{d}$

or $\mathrm{SS}$ produced $=1852 / 0.8=2315 \mathrm{~kg} / \mathrm{d}$

If SS are removed as underflow with solids concentration $1 \%$ and assuming specific gravity of sludge as 1.0,

Liquid sludge to be removed $=2315 \times 100 / 1=231,500 \mathrm{Lit} / \mathrm{d}$

$$
=231.5 \mathrm{~m}^{3} / \mathrm{d}
$$

Oxygen Requirement: 
1. For carbonaceous demand, oxygen required $=\left(\mathrm{BOD}_{\mathrm{u}}\right.$ removed $)-\left(\mathrm{BOD}_{\mathrm{u}}\right.$ of solids leaving $)$

$$
\begin{aligned}
& =1.47(4167.4 \mathrm{~kg} / \mathrm{d})-1.42(1852 \mathrm{~kg} / \mathrm{d}) \\
& =3,496.3 \mathrm{~kg} / \mathrm{d} \\
& =146 \mathrm{Kg} / \mathrm{h}
\end{aligned}
$$

2. For nitrification,

oxygen required $=4.33(\mathrm{TKN}$ oxidized, $\mathrm{kg} / \mathrm{d})$

Incoming TKN at $8.0 \mathrm{~g} /$ person-day $=122,500 * 8 / 1000=980 \mathrm{~kg} / \mathrm{day}$.

Assume $30 \%$ is removed in primary sedimentation and the balance $686 \mathrm{~kg} / \mathrm{day}$ is oxidized to nitrates. Thus, oxygen required

$$
=4.33 \times 686=2,970.38 \mathrm{~kg} / \mathrm{day}=124 \mathrm{~kg} / \mathrm{h}
$$

3. Total oxygen required

$$
=146+124=270 \mathrm{~kg} / \mathrm{h}
$$

Assuming the capacity of the aerators be $50 \%$ more than net requirements $=1.5 * 270=405 \mathrm{~kg} /$ $\mathrm{h}$

\subsection{Gravity Thickening}

Sludge Thickening

It is necessary to treat properly or dispose the sludge generated during the various stages of wastewater treatment like primary sedimentation and secondary sedimentation.

Primary Sludge: Sludge settled in primary settling tanks comes under this category which contains $3 \%$ to $7 \%$ solids out of which approximately $60 \%$ to $80 \%$ are organic. Primary sludge solids are usually grey in color, slimy, fairly coarse, and with highly obnoxious odours. This sludge is difficult to dewater without treatment; hence digestion is necessary. This type of sludge can be digested readily by aerobic or anaerobic bacteria under favourable operating conditions. 
Secondary Sludge: This type of sludge from secondary settling tanks has commonly a brownish, flocculent appearance and an earthy odour. It consists mainly of microorganism containing $75 \%$ to $90 \%$ organic fraction and remaining inert materials. The organic matter may be assumed to have a specific gravity of 1.01 to 1.05 , depending on its source, whereas the inorganic particles have high a specific gravity of about 2.5 .

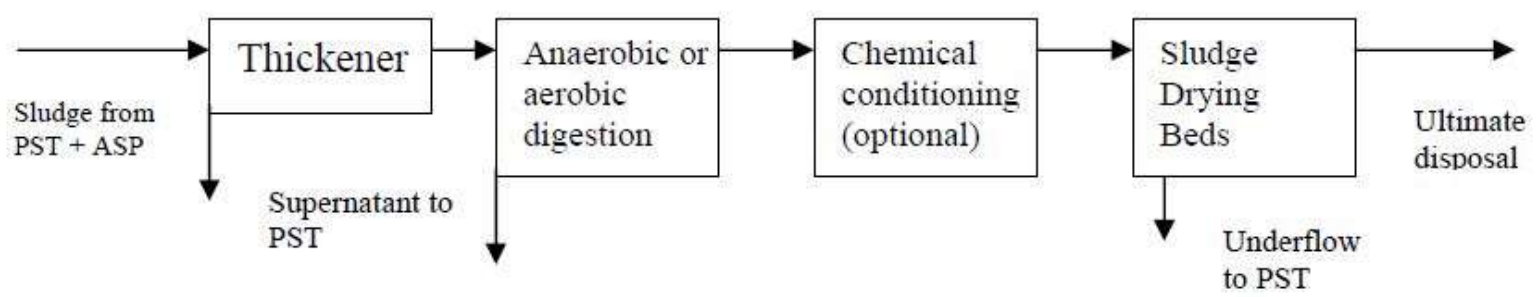

Figure 35: Flow Sheet for Biological Sludge Treatment

Gravity thickening is accomplished in a tank similar in design to a sedimentation tank. This is most commonly used for concentrating the sludge for achieving saving in the digester volume and sludge handing cost. This is used for primary sludge and for combine primary and secondary sludge, and it is not suitable for ASP sludge alone. When the ASP sludge is more than $40 \%$ (weight ratio) of the total combined sludge, gravity thickening is not effective and other methods of thickening have to be considered.

Gravity thickeners can be operated either as continuous flow or fill and draw type, with or without chemical addition. The thickened sludge is withdrawn from the bottom of the tank and pumped to the digester. The supernatant is returned to the PST. Use of slow stirring improves efficiency. Continuous feed tanks are circular in shape with central feeding and overflow at the periphery. The side water depth is kept about $3.0 \mathrm{~m}$. Due to relatively high concentration of the solids, as compared to PST or SST, the settling in thickeners will follow hindered settling in the beginning and compaction at later stage. Concentration of the underflow solids is governed by the depth of sludge blanket up to $1 \mathrm{~m}$ beyond which there is very little influence of the blanket. 
Thickeners are designed for hydraulic loading of 20 to $25 \mathrm{~m} 3 / \mathrm{m} 2 . d$. Loading rates lesser than $12 \mathrm{~m} 3 / \mathrm{m} 2 . \mathrm{d}$ are likely to give very high solids concentration, which may require dilution with plant effluent for transporting. The underflow solid concentration will increase with increase in detention time, and detention time of about $24 \mathrm{~h}$ will produce maximum compaction.

During peak condition, lesser detention time is allowed to keep the sludge blanket sufficiently below the overflow weirs to prevent excessive solids carryover. The surface loading rates for various types

of sludge are given in the Table 10 below.

Table 10: Surface Loading Rates and Solid Concentration Typically Achieved in Thickeners

\begin{tabular}{|c|c|c|}
\hline Type of sludge & $\begin{array}{l}\text { Solid surface loading } \\
(\mathrm{kg} / \mathrm{m} 2 . \text { day })\end{array}$ & $\begin{array}{l}\text { Thickened sludge solids } \\
\text { concentration, } \%(\mathrm{~g} / \mathrm{L})\end{array}$ \\
\hline \multicolumn{3}{|l|}{ Separate sludge } \\
\hline Primary & $90-140$ & $5-10(50$ to 100$)$ \\
\hline Activated & $25-30$ & $2.5-3.0(25$ to 30$)$ \\
\hline Trickling filter & $40-45$ & $7-9(70$ to 90$)$ \\
\hline \multicolumn{3}{|l|}{ Combined sludge } \\
\hline Primary + Activated & $30-50$ & $4-8(40$ to 80$)$ \\
\hline Primary + Trickling filter & $50-60$ & $7-9(70$ to 90$)$ \\
\hline
\end{tabular}

The total volume of sludge from primary settling tank \& secondary clarifiers

\section{Sludge produced from primary sedimentation}

- Specific gravity of sludge $=1.03 \mathrm{~g} / \mathrm{Cu} \mathrm{cm}$

- Typical solids content $=4.5$ percent

- TSS $200 \mathrm{mg} / \mathrm{lit}$

Computing average quantity of sludge produced per day:

Amount of solids produced at a removal rate of 60 percent

$=200 \mathrm{mg} / \mathrm{lit} * 0.60 * 38,587.5 \mathrm{Cum} /$ day $* 1 / 1000,000 * 1000$

$=4,630.5 \mathrm{~kg} / \mathrm{d}$ 
Computing the volume of sludge produced per day

Volume of sludge at specific gravity of 1.03

Specific gravity $1.03 \mathrm{~g} / \mathrm{cu} \mathrm{cm}$

Volume of sludge Produced=46,305/(1.03*10)

$=463.05 \mathrm{Cum} /$ day

Volume of Sludge produced from activated sludge system

$=231.2 \mathrm{Cum} /$ day

Total Volume of sludge produced $=231.2+463.05$

$$
=694.25 \mathrm{Cum} / \text { day }
$$

Total mass of sludge produced $\quad=4,630.5+2,315 \mathrm{~kg}$

$$
=6,945.5 \mathrm{Kg}
$$

Sizing of Gravity Thickener-

Assumptions

Concentration of the solids are $4.5 \%$ for combined sludge

Size a gravity thickener based on a solids loading of $50 \mathrm{~kg} / \mathrm{m}^{2} / \mathrm{d}$.

Underflow of $8.0 \%$ and $95 \%$ solids capture.

$\begin{array}{ll}\text { tank area required } & =\frac{6,945.5 \mathrm{~kg} / \mathrm{d}}{50 \mathrm{~kg} / \mathrm{m}^{2} / \mathrm{d}}=138.9 \mathrm{~m}^{2} \\ \text { diameter } & =\frac{(138.9 \times 4)}{\pi}=.5=13.3 \mathrm{~m}\end{array}$

Use a depth of $3 \mathrm{~m}$

$$
\text { volume of applied sludge } \quad=\quad 694 \mathrm{~m}^{3 / \text { day }}
$$

overflow rate of applied sludge $=$

$$
\underline{694 \mathrm{~m}^{3} / \mathrm{d}}=8.3 \mathrm{~m}^{3} \mathrm{~m}^{-1} \mathrm{~d}^{-1}
$$

$13.3 \times 2 \pi$ 


$$
\text { volume of thickened sludge }=\frac{694 \times 0.95}{(8.0 / 100) 1000}=8.24 \mathrm{~m}^{3 / \mathrm{d}}
$$

\subsection{Design of Secondary Clarifiers-}

\section{Design Criteria-}

We shall provide 6 units of circular clarifiers; each will be operating independently.

The design takes into account the average design flow and recirculation. The surface overflow rates at average and peak flow conditions shall not exceed 15 and 40 Cubic meter/sqm Day.

\section{Design Calculations-}

Calculation of Surface area of the clarifier

Design flow to secondary Clarifier

$$
\begin{aligned}
& =\text { Qav }+ \text { Qr-Qw } \\
\text { Qav } & =38,587 \mathrm{Cum} / \text { Day } \\
& =0.4466 \mathrm{Cum} / \mathrm{Sec} \\
\text { Qr } \quad & =25,853 \mathrm{Cum} / \text { Day } \\
& =0.299 \mathrm{Cum} / \mathrm{Sec} \\
\text { Qw } \quad & =231 \mathrm{Cum} / \mathrm{Day} \\
& =0.0027 \mathrm{Cum} / \mathrm{Sec}
\end{aligned}
$$

Design Flow $=0.4466+0.299-0.0027 \mathrm{Cum} / \mathrm{Sec}$

$$
=0.7429 \mathrm{Cum} / \mathrm{Sec}
$$

Design Flow for Each Clarifiers $=0.7429 / 6$

$$
=0.1238 \mathrm{Cum} / \mathrm{Sec}
$$


Assume surface loading rate (SOR) to be $15 \mathrm{~m}$ /day

Area of each clarifier $=$ flow $/$ SOR

$$
\begin{aligned}
& =.1238 * 24 * 60 * 60 / 15 \\
& =713 \mathrm{Sqm}
\end{aligned}
$$

Diameter of Secondary Clarifier $=\operatorname{Sqrt}(713 * 4 / \mathrm{pi})$

$$
=30 \text { meter }
$$

Provide six clarifiers each of diameter 30 meter.

Total area of all the clarifier $=6 * 3.14 * 30 * 30 / 4$

$$
=4239 \mathrm{Sqm}
$$

Check for overflow rate at average flow

Average overflow rate $=$ Qav/area

$$
\begin{aligned}
& =.7429 * 24 * 60 * 60 / 4239 \\
& =15.14 \text { Cubic Meter/ Sqm day }
\end{aligned}
$$

The design need to be revised to optimise the operation and maintenance of the plant.

We need to consider the number of clarifiers to be four from six, which is the assumption in the above calculations.

Considering four units of clarifiers, the relevant calculations are shown below-

Design Flow $=0.4466+0.299-0.0027 \mathrm{Cum} / \mathrm{Sec}$

$$
=0.7429 \mathrm{Cum} / \mathrm{Sec}
$$

Design Flow for Each Clarifiers $=0.7429 / 4$

$$
=0.1857 \mathrm{Cum} / \mathrm{Sec}
$$

Assume surface loading rate (SOR) to be $15 \mathrm{~m} /$ day

Area of each clarifier $=$ flow $/ \mathrm{SOR}$

$$
\begin{aligned}
& =.1857 * 24 * 60 * 60 / 15 \\
& =1069 \mathrm{Sqm}
\end{aligned}
$$

Diameter of Secondary Clarifier= Sqrt $(1069 * 4 /$ pi $)$

$$
=37 \text { meter }
$$


Provide 4 clarifiers each of diameter 37 meter.

Total area of all the clarifier $=4 * 3.14 * 37 * 37 / 4$

$$
=4299 \mathrm{Sqm}
$$

Check for overflow rate at average flow

Average overflow rate $=$ Qav/area

$$
\begin{aligned}
& =0.7429 * 24 * 60 * 60 / 4299 \\
& =14.93 \text { Cubic Meter/ Sqm day which is satisfactory }
\end{aligned}
$$

Check for Overflow Rate at peak Flow

At the peak flow the flow is almost double, which will result in the SOR to be 30 from 15 for the average flow and is less than 40 as per design criteria and hence design check passes the criteria.

\section{Design depth of the Clarifier}

Provide average depth to be $3.5 \mathrm{~m}$

Total depth of Clarifier $=3.5$

\section{Detention Time}

Average volume of clarifier $=3.14 * 37 * 37 * 3.5 / 4$

$$
=3,761 \text { Cum }
$$

Detention time for average flow with recirculation

$$
\begin{aligned}
& =3761 / .1857 * 3600 \\
& =5.6 \text { Hours. }
\end{aligned}
$$

This will be similar for peak flow condition also. 


\subsection{Design of Continuous Stirred Tank Reactor (CSTR) Digester}

\section{Sludge produced from Gravity Thickener}

Volume of sludge produced $=8.24 \mathrm{Cum}$ per day and $8 \%$ concentration of solids

Mass of solids in sludge $=.08 * 8.24 * 1000=659.2 \mathrm{Kg}$

SRT, $\theta=$ Mass of solids in the bioreactor $(\mathrm{kg}) /$ Solid wastage rate $(\mathrm{kg} / \mathrm{d})$

Assume $\theta=20$ days

Solid waste rate $=659.2 / 20=32.96 \mathrm{~kg} /$ day

HRT, $\theta=$ Volume of Reactor (V)/Influent flow rate (Q)

HRT is same as SRT $=20$

Volume of reactor $(\mathrm{V})=\mathrm{HRT}^{*}$ influent flow $(\mathrm{Q})$

$$
\begin{aligned}
& =20 * 8.24 \mathrm{Cum} \\
& =164.8 \mathrm{Cum}
\end{aligned}
$$

Size of reactor $=$ cylindrical with diameter $5 \mathrm{~m}$ and length $8.5 \mathrm{~m}$

\subsection{Chlorine Disinfection}

\section{Type}

Chlorine is available for disinfection in gas, liquid (hypochlorite solution), and pellet (hypochlorite tablet) form. The type of chlorine should be carefully evaluated during the facility planning process. The use of chlorine gas or liquid will be most dependent on the size of the facility and the chlorine dose required. Large quantities of chlorine, such as are contained in ton cylinders and tank cars, can present a considerable hazard to plant personnel and to the surrounding area should such containers develop leaks. Both monetary cost and the potential public exposure to chlorine should be considered when making the final determination. 


\section{Dosage}

For disinfection, the capacity shall be adequate to produce an effluent that will meet the applicable bacterial limits specified by the regulatory agency for that installation. Required disinfection capacity will vary, depending on the uses and points of application of the disinfection chemical. The chlorination system shall be designed on a rational basis and calculations justifying the equipment sizing and number of units shall be submitted for the whole operating range of flow rates for the type of control to be used. System design considerations shall include the controlling wastewater flow meter (sensitivity and location), telemetering equipment and chlorination controls. For normal domestic wastewater, the following may be used as a guide in sizing chlorination facilities.

Table 11: Type of Treatment \& Dosage

\begin{tabular}{|l|l|}
\hline Type of Treatment & Dosage \\
\hline Trickling filter plant effluent & $10 \mathrm{mg} / \mathrm{L}$ \\
\hline Activated sludge plant effluent & $8 \mathrm{mg} / \mathrm{L}$ \\
\hline Tertiary filtration effluent & $6 \mathrm{mg} / \mathrm{L}$ \\
\hline Nitrified effluent & $6 \mathrm{mg} / \mathrm{L}$ \\
\hline
\end{tabular}

The amount of chlorine required per day $=38,587 \mathrm{Cum} * 8 \mathrm{mg} / \mathrm{lit}=308 \mathrm{Kg} / \mathrm{day}$

Assume efficiency of system be $95 \%$

The required chlorine per day $=308 / .95=325 \mathrm{Kg} /$ day

The size of contact Tank

For a contact period of say 20 minutes

Volume of tank $=38,587 * 15 /(24 * 60)$

$=401 \mathrm{Cum}$

Size of Contact chamber (Tank) Say $11 \mathrm{~m} * 11 \mathrm{M} * 4 \mathrm{M}$ 


\section{Containers}

\section{Ton Containers}

The use of one-ton $(907 \mathrm{~kg}$ ) containers should be considered where the average daily chlorine consumption is over 150 pounds $(68 \mathrm{~kg})$.

\section{Tank Cars}

At large installations, the use of tank cars, generally accompanied by evaporators, may be considered. Area wide public safety shall be evaluated. No interruption of chlorination shall be permitted during tank car switching.

The tank car being used for the chlorine supply shall be located on a dead end, level track that is a private siding. The tank car shall be protected from accidental bumping by other railway cars by a locked derail device or a closed locked switch or both. The area shall be clearly posted "DANGER-CHLORINE". The tank car shall be secured by adequate fencing with gates provided with locks for personnel and rail access.

The tank car site shall be provided with a suitable operating platform at the unloading point for easy access to the protective housing or the tank car for connection of flexible feedlines and valve operation. Adequate area lighting shall be provided for night time operation and maintenance.

\section{Liquid Hypochlorite Solutions}

Storage containers for hypochlorite solutions shall be of sturdy, non-metallic lined construction and shall be provided with secure tank tops and pressure relief and overflow piping. Storage tanks should be either located or vented outside. Provision shall be made for adequate protection from light and extreme temperatures. Tanks shall be located where leakage will not cause corrosion or damage to other equipment. A means of secondary containment shall be provided to contain spills and facilitate cleanup. Due to deterioration of hypochlorite solutions over time, it is recommended that containers not be sized to hold more than one month's needs. At larger facilities and locations where delivery is not a problem, it may be desirable to limit on-site storage to one week. 


\section{Equipment}

\section{Scales}

Scales for weighing cylinders and containers shall be provided at all plants using chlorine gas. At large plants, scales of the indicating and recording type are recommended. At least a platform scale shall be provided. Scales shall be of corrosion-resistant material.

\section{Evaporators}

Where manifolding of several cylinders or ton containers will be required to evaporate sufficient chlorine, consideration should be given to the installation of evaporators to produce the quantity of gas required.

\section{Mixing}

The disinfectant shall be positively mixed as rapidly as possible, with a complete mix being effected in 3 seconds. This may be accomplished by either the use of turbulent flow regime or a mechanical flash mixer.

\section{Contact Period and Tank}

For a chlorination system, a minimum contact period of 15 minutes at design peak hourly flow or maximum rate of pumpage shall be provided after thorough mixing. For evaluation of existing chlorine contact tanks, field tracer studies should be done to assure adequate contact time.

The chlorine contact tank shall be constructed so as to reduce short-circuiting of flow to a practical minimum. Tanks not provided with continuous mixing shall be provided with "over-and-under" or "end-around" baffling to minimize short-circuiting.

The tank should be designed to facilitate maintenance and cleaning without reducing effectiveness of disinfection. Duplicate tanks, mechanical scrapers, or portable deck-level vacuum cleaning equipment shall be provided. Consideration should be given to providing skimming devices on all contact tanks. Covered tanks are discouraged. 


\section{Piping and Connections}

Piping systems should be as simple as possible, specifically selected and manufactured to be suitable for chlorine service, with a minimum number of joints. Piping should be well supported and protected against temperature extremes.

Due to the corrosiveness of wet chlorine, all lines designated to handle dry chlorine shall be protected from the entrance of water or air containing water. Even minute traces of water added to chlorine results in a corrosive attack. Low pressure lines made of hard rubber, saran-lined, rubber-lined, polyethylene, polyvinylchloride (PVC), or other approved materials are satisfactory for wet chlorine or aqueous solutions of chlorine.

The chlorine system piping shall be color coded and labeled to distinguish it from other plant piping. Where sulfur dioxide is used, the piping and fittings for chlorine and sulfur dioxide systems shall be designed so that interconnection between the two systems cannot occur.

\section{Standby Equipment and Spare Parts}

Standby equipment of sufficient capacity should be available to replace the largest unit during shutdowns. Spare parts shall be available for all disinfection equipment to replace parts which are subject to wear and breakage.

\section{Chlorinator Water Supply}

An ample supply of water shall be available for operating the chlorinator. Where a booster pump is required, duplicate equipment should be provided, and, when necessary, standby power as well. Adequately filtered plant effluent should be considered for use in the chlorinator.

\section{Leak Detection and Controls}

A bottle of 56 percent ammonium hydroxide solution shall be available for detecting chlorine leaks. Where ton $(907 \mathrm{~kg}$ ) containers or tank cars are used, a leak repair kit approved by the Chlorine Institute shall be provided. Consideration should be given to the provision of caustic soda solution reaction tanks for absorbing the contents of leaking one-ton (907 kg) containers where such containers are in use. Consideration should be given to the installation of automatic gas detection and related alarm equipment. 
6.11.Drawings of the Treatment Units (Dimensions in milimetres)

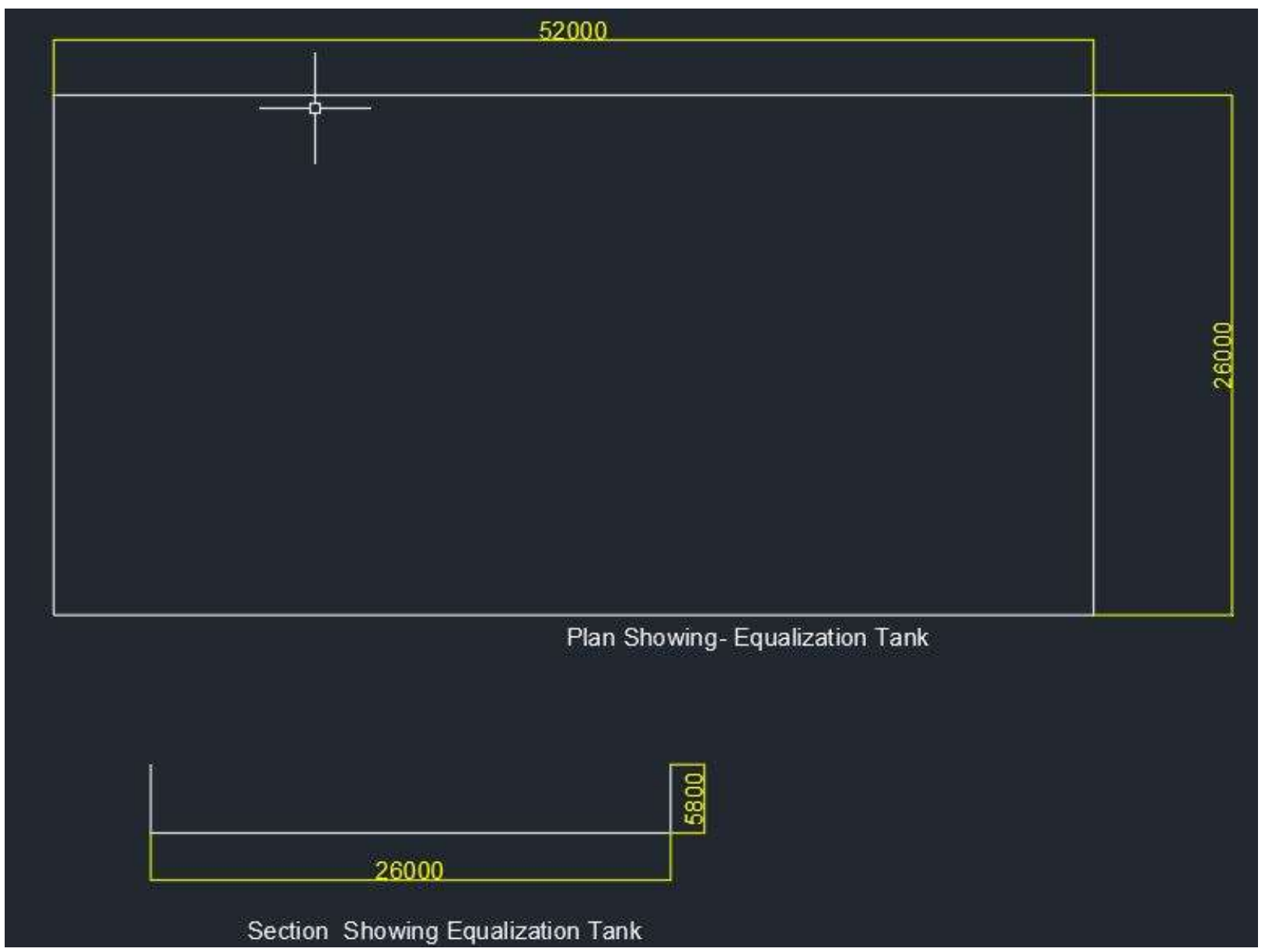

Figure 36: Above Shows Plan \& Section Through Equalization Tank

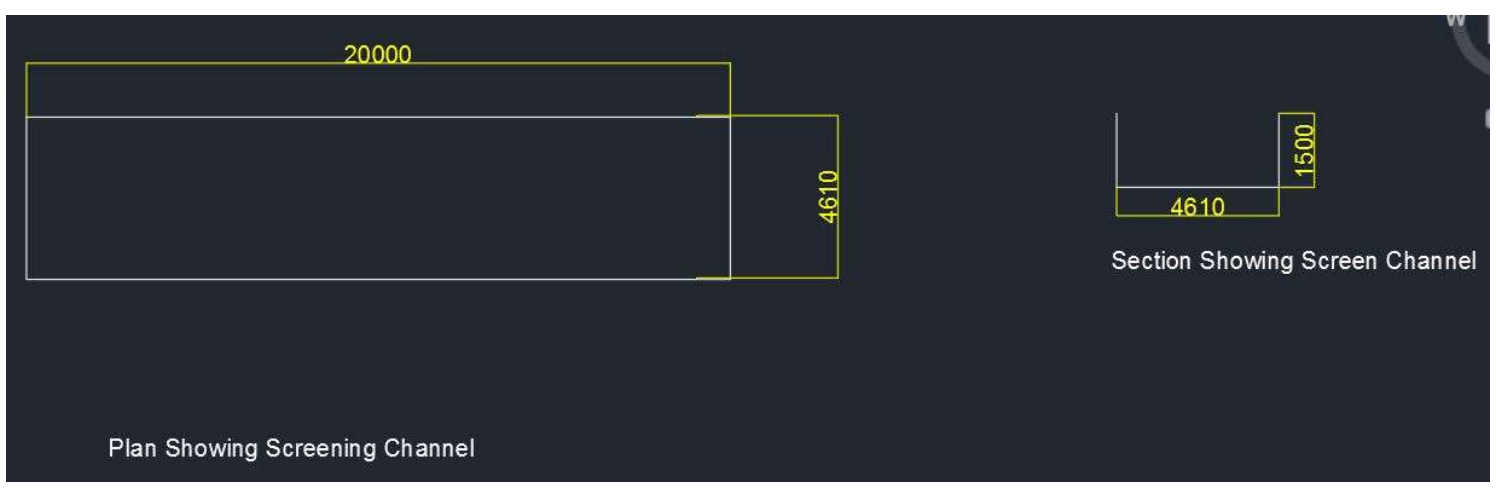

Figure 37: Above Shows Plan and Section for Screening Channel 


\section{0}

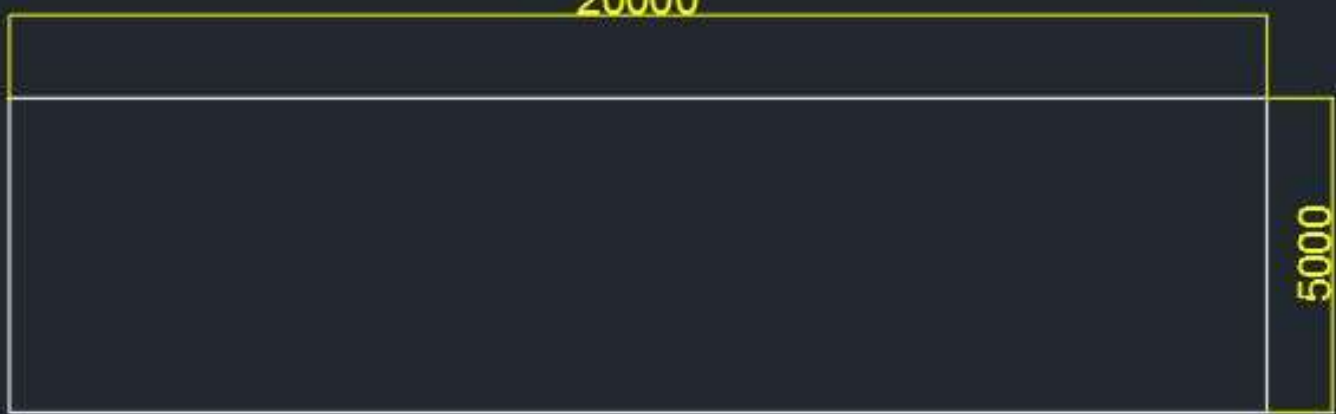

Plan Showing Grit Chamber

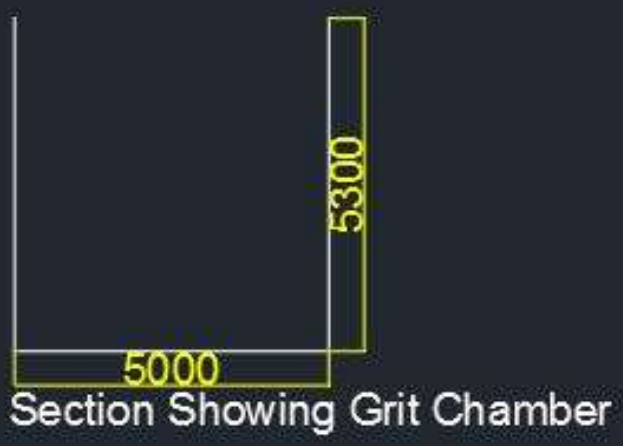

Figure 38: Above Shows Plan \& Section for Grit Chamber

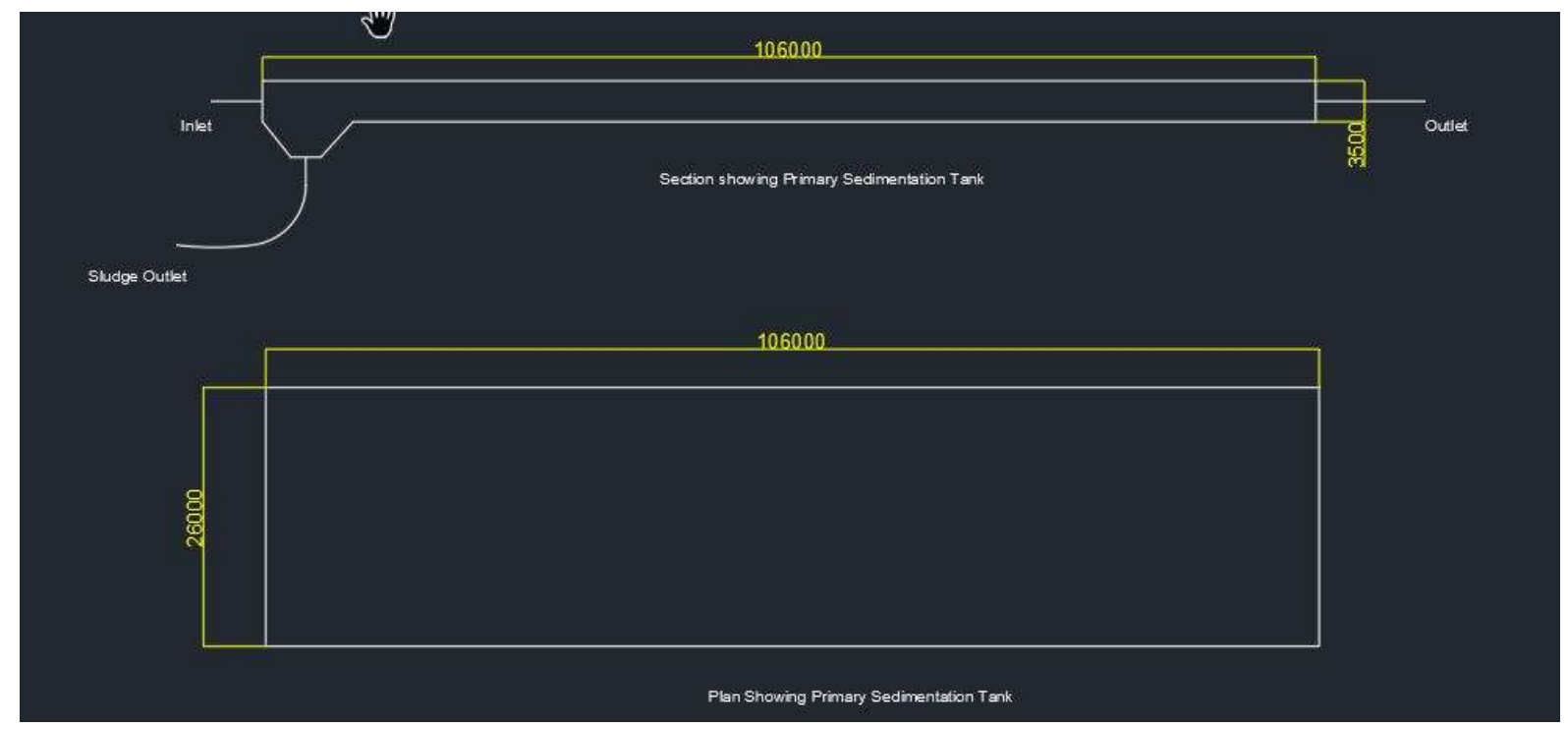

Figure 39: Above Shows Plan \& Section for Primary Sedimentation Tank 

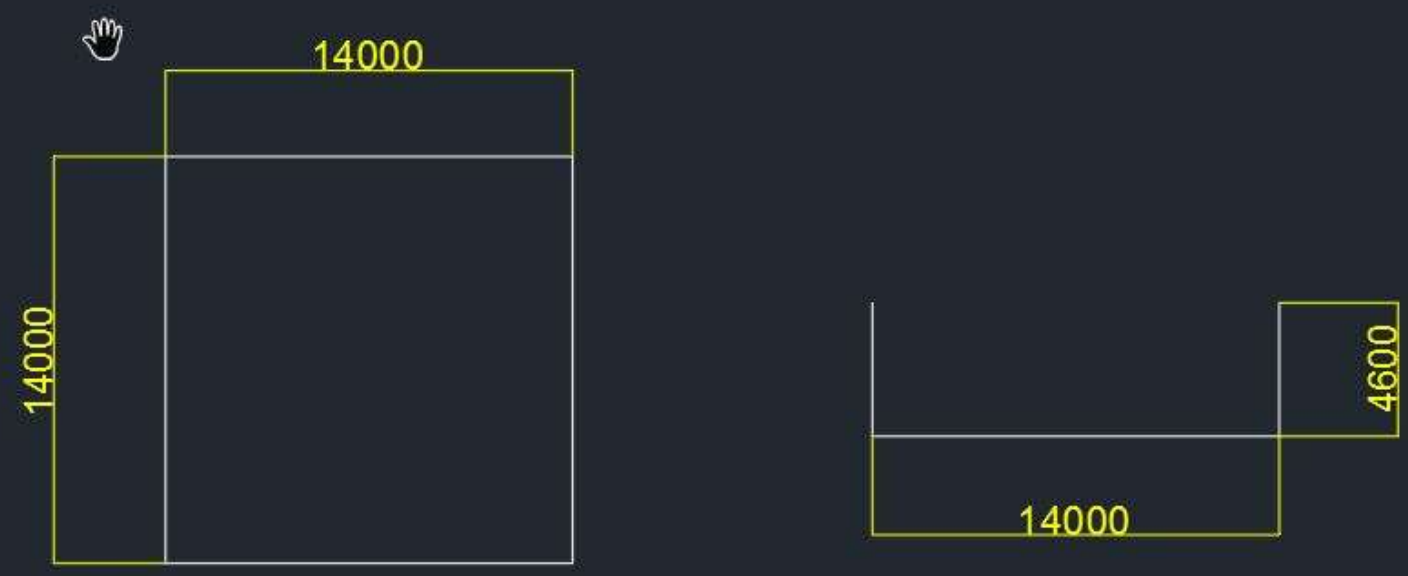

Plan Showing Aeration Tank

Section of Aeration Tank

Figure 40: Figure Above Shows Plan \& Section of Aeration Tank

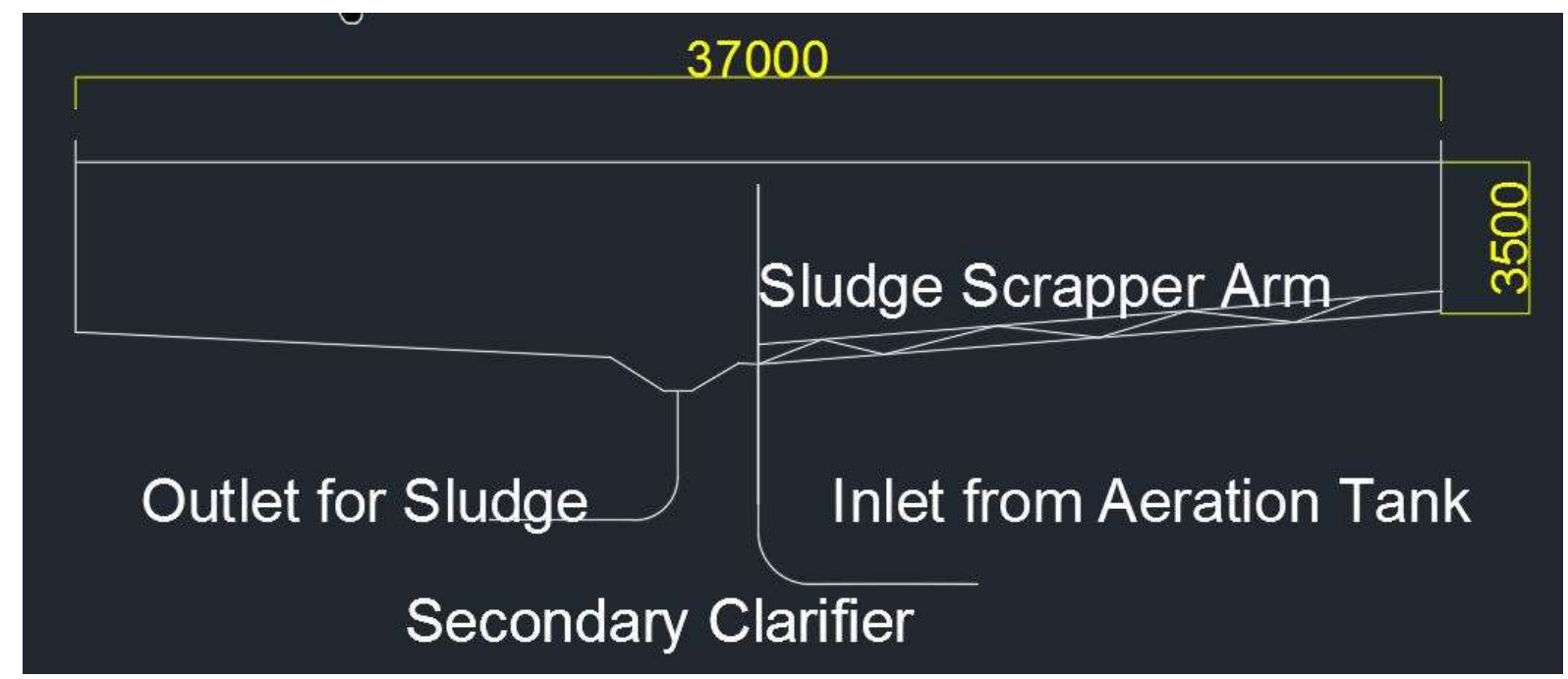

Figure 41: Secondary Clarifier 


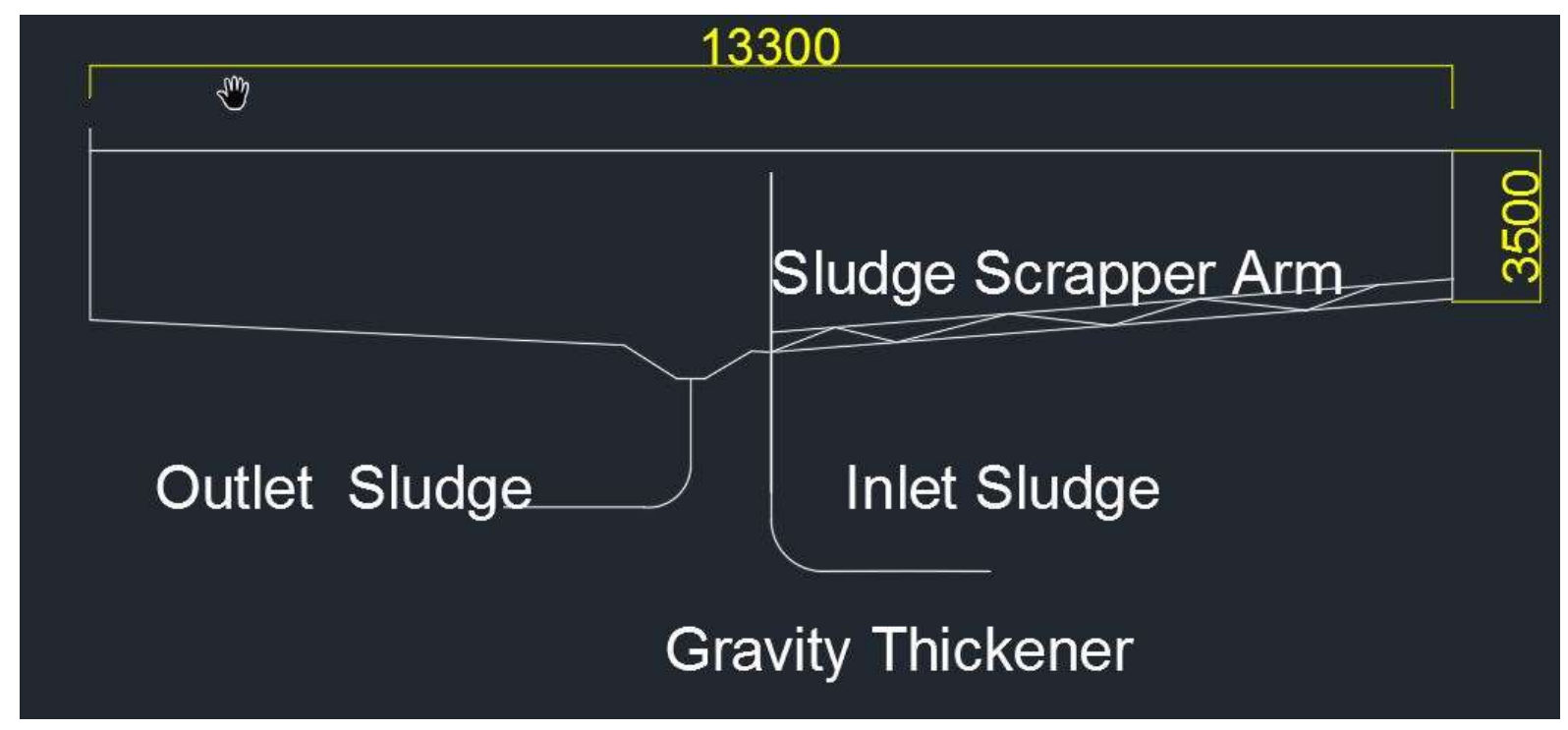

Figure 42: Gravity Thickener

\section{Elevation of CSTR Dia 5m Length $8.5 \mathrm{~m}$}

Figure 43: CSTR 


\section{Plan of Chlorination Tank $11 \mathrm{~m} \times 11 \mathrm{~m}$}

Figure 44: Plan Showing Chlorination Tank 


\subsection{Hydraulic Diagram of WWTP}

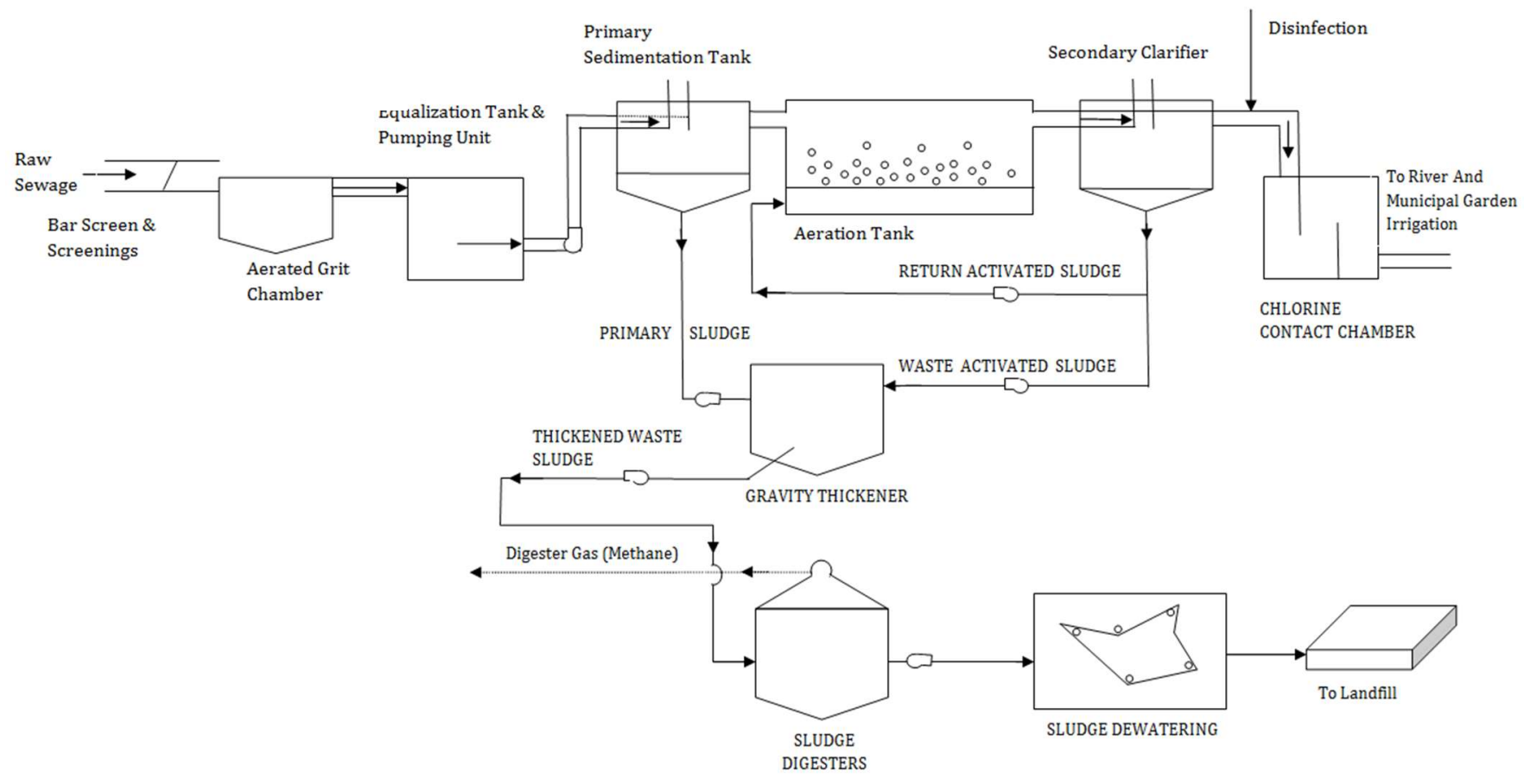

Figure 45: Hydraulic Profile of WWTP 


\section{Design Calculations without Primary Sedimentation}

The size of the following units will not be impacted due to non-provision of primary sedimentation and therefore, their dimensions will same as case I:

1. Equalization Tank

2. Screens

3. Screening Channel

4. Aerated Grit Chamber

\subsection{Design of Activated Sludge System}

Design of Completely Mixed Activated Sludge System

Wastewater Flow(Average)

$\mathrm{BOD}_{5} 54 \mathrm{~g} /$ person-day

BOD Ultimate $\left(1.47 * \mathrm{BOD}_{5}\right)$

Total kjeldahl nitrogen (TKN) ( 8 g/person-day)

Phosphorus ( 2 g/person-day)

Winter Temperature in Aeration Tank

Yield Coefficient " Y"

Decay constant $\mathrm{K}_{\mathrm{d}}$

Specific substrate utilization rate
=38,587 Cum Per Day

$=0.447 \mathrm{Cum}$ Per Sec

$=171.43 \mathrm{mg}$ Per Litre

$=252 \mathrm{mg}$ Per Litre

$=25.4 \mathrm{mg}$ Per Litre

$=6.35 \mathrm{mg}$ Per Litre

$=18$ Degree Centigrade

$=0.6$

$=0.07$ per day

$=(0.038 \mathrm{mg} / \mathrm{l})^{-1}(\mathrm{~h})^{-1}$ at $18^{\circ} \mathrm{C}$

Assume $30 \%$ raw $\mathrm{BOD}_{5}$ is removed in primary sedimentation- Not Applicable

$\mathrm{BOD}_{5}$ going to aeration is

$=171.4 \mathrm{mg}$ Per Litre

Selection of $\theta_{c}, t$ and MLSS concentration: 
Considering the operating temperature and the desire to have nitrification and good sludge settling characteristics, adopt $\theta_{\mathrm{c}}=5 \mathrm{~d}$. As there is no special fear of toxic inflows, the HRT, $\mathrm{t}$ may be kept between 3-4 h, and MLSS $=4000 \mathrm{mg} / \mathrm{l}$.

Effluent $\mathrm{BOD}_{5}$ :

Substrate concentration, $S=\frac{1}{q Y}\left(1 / \theta_{c}+k_{d}\right)=\frac{1}{(0.038)(0.6)}(1 / 5+0.07)$

$\mathrm{S}=12 \mathrm{mg} / 1$

Assume suspended solids (SS) in effluent

$\mathrm{VSS} / \mathrm{SS}$
$=20 \mathrm{mg} / 1$

$=0.8$.

If degradable fraction of volatile suspended solids (VSS) $\quad=0.7$ (check later)

$\mathrm{BOD}_{5}$ of VSS in effluent $=0.7(0.8 \times 20)$ $=11 \mathrm{mg} / \mathrm{l}$.

Thus, total effluent $\mathrm{BOD}_{5}=12+11$

$=23 \mathrm{mg} / \mathrm{l}$ (acceptable).

Aeration Tank:

$\left.V X=\frac{Y Q \theta_{c}}{1+K_{d} \theta_{c}}-S\right)$ where $X=0.8(4000)=3200 \mathrm{mg} / \mathrm{l}$

or $3200 \mathrm{~V}=\underline{(0.6)(5)(38,587.5)(171.4-12)}$

$[1+(0.07)(5)]$

$\mathrm{V}=4,271.3 \mathrm{~m}^{3}$ Detention time, $\mathrm{t}=\frac{4,271.3 \times 24}{38,587}=2.6$ hours 
$\mathrm{F} / \mathrm{M}=\underline{(171.4-12)(38,587)}=0.45 \mathrm{~kg} \mathrm{BOD}_{5}$ per $\mathrm{kg}$ MLSS per day (3200) $(4,271.3))$

Let the aeration tank be in the form of four square shaped compartments operated in two parallel rows, each with two cells measuring $16.4 \mathrm{~m} \times 16.4 \mathrm{~m} \times 4.0 \mathrm{~m}$

Return Sludge Pumping:

If suspended solids concentration of return flow is $1 \%=10,000 \mathrm{mg} / 1$

$$
\begin{aligned}
& \mathrm{R}=\frac{\mathrm{MLSS}}{(10000)-\mathrm{MLSS}}=0.67 \\
& \mathrm{Q}_{\mathrm{r}}=0.67 \times 38,587=25,853 \mathrm{~m}^{3} / \mathrm{d}
\end{aligned}
$$

Surplus Sludge Production:

Net VSS produced $\mathrm{Q}_{\mathrm{w}} \mathrm{X}_{\mathrm{r}}=\underline{\mathrm{VX}}=\underline{(3200)(4,271)}\left(10^{3} / 10^{6}\right)=2,733.44 \mathrm{~kg} / \mathrm{d}$ (5)

or SS produced $=2,733.44 / 0.8=3,416.8 \mathrm{~kg} / \mathrm{d}$

If $\mathrm{SS}$ are removed as underflow with solids concentration $1 \%$ and assuming specific gravity of sludge as 1.0,

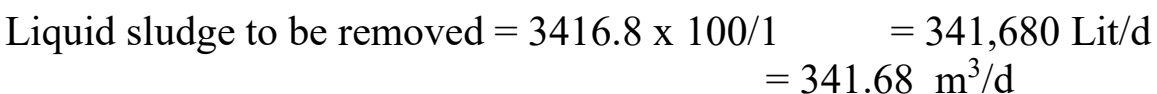


Oxygen Requirement:

4. For carbonaceous demand,

oxygen required $=\left(\mathrm{BOD}_{\mathrm{u}}\right.$ removed $)-\left(\mathrm{BOD}_{\mathrm{u}}\right.$ of solids leaving $)$

$$
\begin{aligned}
& =1.47(6150.7 \mathrm{~kg} / \mathrm{d})-1.42(2733.44 \mathrm{~kg} / \mathrm{d}) \\
& =5,159 \mathrm{~kg} / \mathrm{d} \\
& =215 \mathrm{Kg} / \mathrm{h}
\end{aligned}
$$

5. For nitrification,

oxygen required $=4.33(\mathrm{TKN}$ oxidized, $\mathrm{kg} / \mathrm{d})$

Incoming TKN at $8.0 \mathrm{~g} /$ person-day $=122,500 * 8 / 1000=980 \mathrm{~kg} /$ day.

Thus, oxygen required

$$
=4.33 \times 980=4,243.4 \mathrm{~kg} / \text { day }=176.8 \mathrm{~kg} / \mathrm{h}
$$

6. Total oxygen required

$$
=215+176.8=391.8 \mathrm{~kg} / \mathrm{h}
$$

Assuming the capacity of the aerators be $50 \%$ more than net requirements $=1.5 * 391.8=588$ $\mathrm{kg} / \mathrm{h}$

\subsection{Design of Secondary Clarifiers}

Design Criteria-

We shall provide 6 units of circular clarifiers; each will be operating independently.

The design takes into account the average design flow and recirculation. The surface overflow rates at average and peak flow conditions shall not exceed 15 and 40 Cubic meter/sqm Day.

\section{Design Calculations-}

Calculation of Surface area of the clarifier

Design flow to secondary Clarifier

$$
\begin{aligned}
& =\mathrm{Qav}+\mathrm{Qr}-\mathrm{Qw} \\
\mathrm{Qav} & =38,587 \mathrm{Cum} / \text { Day }
\end{aligned}
$$




$$
\begin{aligned}
& =0.4466 \mathrm{Cum} / \mathrm{Sec} \\
\text { Qr } \quad & =25,853 \mathrm{Cum} / \text { Day } \\
& =0.299 \mathrm{Cum} / \mathrm{Sec} \\
\text { Qw } & =231 \mathrm{Cum} / \text { Day } \\
& =0.0027 \mathrm{Cum} / \mathrm{Sec}
\end{aligned}
$$

Design Flow $=0.4466+0.299-0.0027 \mathrm{Cum} / \mathrm{Sec}$

$$
=0.7429 \mathrm{Cum} / \mathrm{Sec}
$$

Design Flow for Each Clarifiers $=0.7429 / 6$

$$
=0.1238 \mathrm{Cum} / \mathrm{Sec}
$$

Assume surface loading rate (SOR) to be $15 \mathrm{~m}$ /day

Area of each clarifier $=$ flow $/$ SOR

$$
\begin{aligned}
& =.1238 * 24 * 60 * 60 / 15 \\
& =713 \mathrm{Sqm}
\end{aligned}
$$

Diameter of Secondary Clarifier $=$ Sqrt $(713 * 4 /$ pi $)$

$$
=30 \text { meter }
$$

Provide six clarifiers each of diameter 30 meter.

Total area of all the clarifier $=6 * 3.14 * 30 * 30 / 4$

$$
=4239 \mathrm{Sqm}
$$

Check for overflow rate at average flow

Average overflow rate $=$ Qav/area

$$
\begin{aligned}
& =.7429 * 24 * 60 * 60 / 4239 \\
& =15.14 \text { Cubic Meter/ Sqm day }
\end{aligned}
$$

The design need to be revised to optimise the operation and maintenance of the plant.

We need to consider the number of clarifiers to be four from six, which is the assumption in the above calculations.

Considering four units of clarifiers, the relevant calculations are shown below-

Design Flow $=0.4466+0.299-0.0027 \mathrm{Cum} / \mathrm{Sec}$ 
$=0.7429 \mathrm{Cum} / \mathrm{Sec}$

Design Flow for Each Clarifiers $=0.7429 / 4$

$=0.1857 \mathrm{Cum} / \mathrm{Sec}$

Assume surface loading rate (SOR) to be $15 \mathrm{~m} /$ day

Area of each clarifier $=$ flow $/ \mathrm{SOR}$

$$
\begin{aligned}
& =.1857 * 24 * 60 * 60 / 15 \\
& =1069 \mathrm{Sqm}
\end{aligned}
$$

Diameter of Secondary Clarifier= Sqrt $(1069 * 4 /$ pi $)$

$$
=37 \text { meter }
$$

Provide 4 clarifiers each of diameter 37 meter.

Total area of all the clarifier $=4 * 3.14 * 37 * 37 / 4$

$$
=4299 \mathrm{Sqm}
$$

Check for overflow rate at average flow

Average overflow rate $=$ Qav/area

$$
\begin{aligned}
& =0.7429 * 24 * 60 * 60 / 4299 \\
& =14.93 \text { Cubic Meter/ Sqm day which is satisfactory }
\end{aligned}
$$

Check for Overflow Rate at peak Flow

At the peak flow the flow is almost double, which will result in the SOR to be 30 from 15 for the average flow and is less than 40 as per design criteria and hence design check passes the criteria.

\section{Design depth of the Clarifier}

Provide average depth to be $3.5 \mathrm{~m}$

Provide free Board to be $0.6 \mathrm{~m}$

Total depth of Clarifier $=3.5+0.6$

$$
=4.1 \mathrm{~m}
$$

\section{Detention Time}

Average volume of clarifier $=3.14 * 37 * 37 * 3.5 / 4$ 


$$
=3,761 \mathrm{Cum}
$$

Detention time for average flow with recirculation

$$
\begin{aligned}
& =3761 / .1857 * 3600 \\
& =5.6 \text { Hours. }
\end{aligned}
$$

This will be similar for peak flow condition also.

\subsection{Gravity Thickening}

\section{Sludge Thickening}

It is necessary to treat properly or dispose the sludge generated during the various stages of wastewater treatment like primary sedimentation and secondary sedimentation.

Primary Sludge: Sludge settled in primary settling tanks comes under this category which contains $3 \%$ to $7 \%$ solids out of which approximately $60 \%$ to $80 \%$ are organic. Primary sludge solids are usually gray in color, slimy, fairly coarse, and with highly obnoxious odours. This sludge is difficult to dewater without treatment; hence digestion is necessary. This type of sludge can be digested readily by aerobic or anaerobic bacteria under favourable operating conditions.

Secondary Sludge: This type of sludge from secondary settling tanks has commonly a brownish, flocculent appearance and an earthy odour. It consists mainly of microorganism containing $75 \%$ to $90 \%$ organic fraction and remaining inert materials. The organic matter may be assumed to have a specific gravity of 1.01 to 1.05 , depending on its source, whereas the inorganic particles have high a specific gravity of about 2.5 .

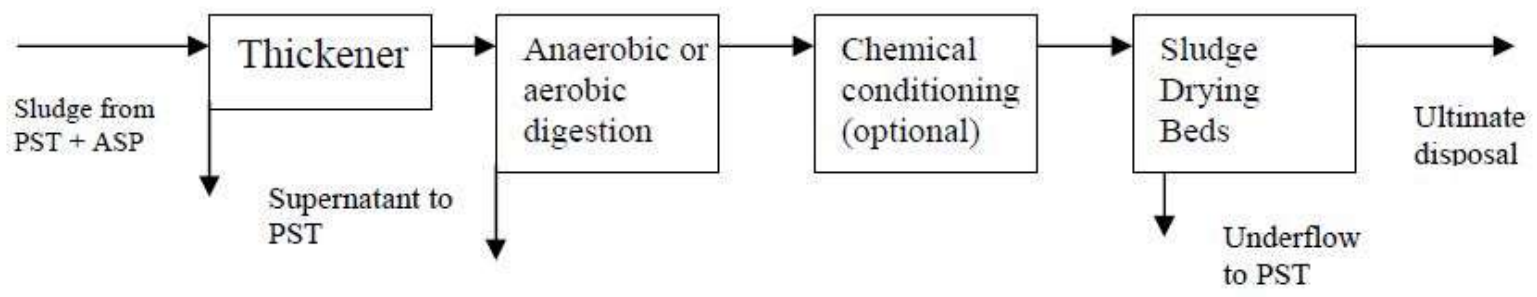

Figure 46: Flow Sheet for Biological Sludge Treatment 
Gravity thickening is accomplished in a tank similar in design to a sedimentation tank. This is most commonly used for concentrating the sludge for achieving saving in the digester volume and sludge handing cost. This is used for primary sludge and for combine primary and secondary sludge, and it is not suitable for ASP sludge alone. When the ASP sludge is more than $40 \%$ (weight ratio) of the total combined sludge, gravity thickening is not effective and other methods of thickening have to be considered.

Gravity thickeners can be operated either as continuous flow or fill and draw type, with or without chemical addition. The thickened sludge is withdrawn from the bottom of the tank and pumped to the digester. The supernatant is returned to the PST. Use of slow stirring improves efficiency. Continuous feed tanks are circular in shape with central feeding and overflow at the periphery. The side water depth is kept about $3.0 \mathrm{~m}$. Due to relatively high concentration of the solids, as compared to PST or SST, the settling in thickeners will follow hindered settling in the beginning and compaction at later stage. Concentration of the underflow solids is governed by the depth of sludge blanket up to $1 \mathrm{~m}$ beyond which there is very little influence of the blanket.

Thickeners are designed for hydraulic loading of 20 to $25 \mathrm{~m} 3 / \mathrm{m} 2 . d$. Loading rates lesser than $12 \mathrm{~m} 3 / \mathrm{m} 2 . \mathrm{d}$ are likely to give very high solids concentration, which may require dilution with plant effluent for transporting. The underflow solid concentration will increase with increase in detention time, and detention time of about $24 \mathrm{~h}$ will produce maximum compaction.

During peak condition, lesser detention time is allowed to keep the sludge blanket sufficiently below the overflow weirs to prevent excessive solids carryover. The surface loading rates for various types of sludge are given in the Table 11 below. 
Table 12: Surface Loading Rates and Solid Concentration Typically Achieved in Thickeners

\begin{tabular}{|l|l|l|}
\hline Type of sludge & $\begin{array}{l}\text { Solid surface loading } \\
(\mathrm{kg} / \mathrm{m} 2 . \text { day })\end{array}$ & $\begin{array}{l}\text { Thickened sludge solids } \\
\text { concentration, \% (g/L) }\end{array}$ \\
\hline Separate sludge & $90-140$ & $5-10(50$ to 100$)$ \\
\hline Primary & $25-30$ & $2.5-3.0(25$ to 30$)$ \\
\hline Activated & $40-45$ & $7-9(70$ to 90$)$ \\
\hline Trickling filter & \multicolumn{2}{|l}{} \\
\hline Combined sludge & $4-8(40$ to 80$)$ \\
\hline Primary + Activated & $30-50$ & $7-9(70$ to 90$)$ \\
\hline Primary + Trickling filter & $50-60$ & \\
\hline
\end{tabular}

\section{Sludge produced from Secondary Clarifier-}

Volume of Sludge produced from activated sludge system

$=341.68 \mathrm{Cum} /$ day

Total Volume of sludge produced $=341.68 \mathrm{Cum} /$ day

Total mass of sludge produced $\quad=3416.8 \mathrm{~kg}$

Sizing of Gravity Thickener-

Assumptions

Concentration of the solids are $4.5 \%$ for sludge

Size a gravity thickener based on a solids loading of $30 \mathrm{~kg} / \mathrm{m}^{2} / \mathrm{d}$.

Underflow of $8.0 \%$ and $95 \%$ solids capture.

$\begin{array}{ll}\text { tank area required } & =\frac{3416.8 \mathrm{~kg} / \mathrm{d}}{30 \mathrm{~kg} / \mathrm{m}^{2} / \mathrm{d}}=113.8 \mathrm{~m}^{2} \\ \text { diameter } & \left.=\frac{(113.8 \times 4)}{\pi}\right)^{0.5}=12.1 \mathrm{~m}\end{array}$

Use a depth of $3 \mathrm{~m}$ 
volume of applied sludge

overflow rate of applied sludge

volume of thickened sludge $=\quad 341.68 \mathrm{~m}^{3} /$ day

$=$

$\underline{341.68 \mathrm{~m}^{3} / \mathrm{d}}$

$=4.5 \mathrm{~m}^{3} \mathrm{~m}^{-1} \mathrm{~d}^{1}$

$12.1 \times 2 \pi$

$=$ $=\quad 4.05 \mathrm{~m}^{3} / \mathrm{d}$

$(8.0 / 100) 1000$

\subsection{Design of Continuous Stirred Tank Reactor (CSTR) Digester}

\section{Sludge produced from Gravity Thickener}

Volume of sludge produced $=4.05$ Cum per day and $8 \%$ concentration of solids

Mass of solids in sludge $=.08 * 4.05 * 1000=324 \mathrm{Kg}$

SRT, $\theta=$ Mass of solids in the bioreactor $(\mathrm{kg}) /$ Solid wastage rate $(\mathrm{kg} / \mathrm{d})$

Assume $\theta=20$ days

Solid waste rate $=324 / 20=16.2 \mathrm{~kg} /$ day

HRT, $\theta=$ Volume of Reactor (V)/Influent flow rate (Q)

HRT is same as $\mathrm{SRT}=20$

Volume of reactor $(\mathrm{V})=\mathrm{HRT}^{*}$ influent flow $(\mathrm{Q})$

$$
\begin{aligned}
& =20 * 4.05 \mathrm{Cum} \\
& =81 \mathrm{Cum}
\end{aligned}
$$

Size of reactor $=$ cylindrical with diameter $4 \mathrm{~m}$ and length $6.5 \mathrm{~m}$ 


\subsection{Chlorine Disinfection}

Type

Chlorine is available for disinfection in gas, liquid (hypochlorite solution), and pellet (hypochlorite tablet) form. The type of chlorine should be carefully evaluated during the facility planning process. The use of chlorine gas or liquid will be most dependent on the size of the facility and the chlorine dose required. Large quantities of chlorine, such as are contained in ton cylinders and tank cars, can present a considerable hazard to plant personnel and to the surrounding area should such containers develop leaks. Both monetary cost and the potential public exposure to chlorine should be considered when making the final determination.

\section{Dosage}

For disinfection, the capacity shall be adequate to produce an effluent that will meet the applicable bacterial limits specified by the regulatory agency for that installation. Required disinfection capacity will vary, depending on the uses and points of application of the disinfection chemical. The chlorination system shall be designed on a rational basis and calculations justifying the equipment sizing and number of units shall be submitted for the whole operating range of flow rates for the type of control to be used. System design considerations shall include the controlling wastewater flow meter (sensitivity and location), telemetering equipment and chlorination controls. For normal domestic wastewater, the following may be used as a guide in sizing chlorination facilities.

Table 13: Type of Treatment \& Dosage

\begin{tabular}{|l|l|}
\hline Type of Treatment & Dosage \\
\hline Trickling filter plant effluent & $10 \mathrm{mg} / \mathrm{L}$ \\
\hline Activated sludge plant effluent & $8 \mathrm{mg} / \mathrm{L}$ \\
\hline Tertiary filtration effluent & $6 \mathrm{mg} / \mathrm{L}$ \\
\hline Nitrified effluent & $6 \mathrm{mg} / \mathrm{L}$ \\
\hline
\end{tabular}

The amount of chlorine required per day $=38,587 \mathrm{Cum} * 8 \mathrm{mg} / \mathrm{lit}=308 \mathrm{Kg} / \mathrm{day}$

Assume efficiency of system be $95 \%$

The required chlorine per day $=308 / .95=325 \mathrm{Kg} /$ day 
The size of contact Tank

For a contact period of say 20 minutes

Volume of tank $=38,587 * 15 /(24 * 60)$

$$
=401 \mathrm{Cum}
$$

Size of Contact chamber (Tank) Say $11 \mathrm{~m} * 11 \mathrm{M} * 4 \mathrm{M}$

\subsection{Drawings of the Treatment Units (Dimensions in millimetres)}

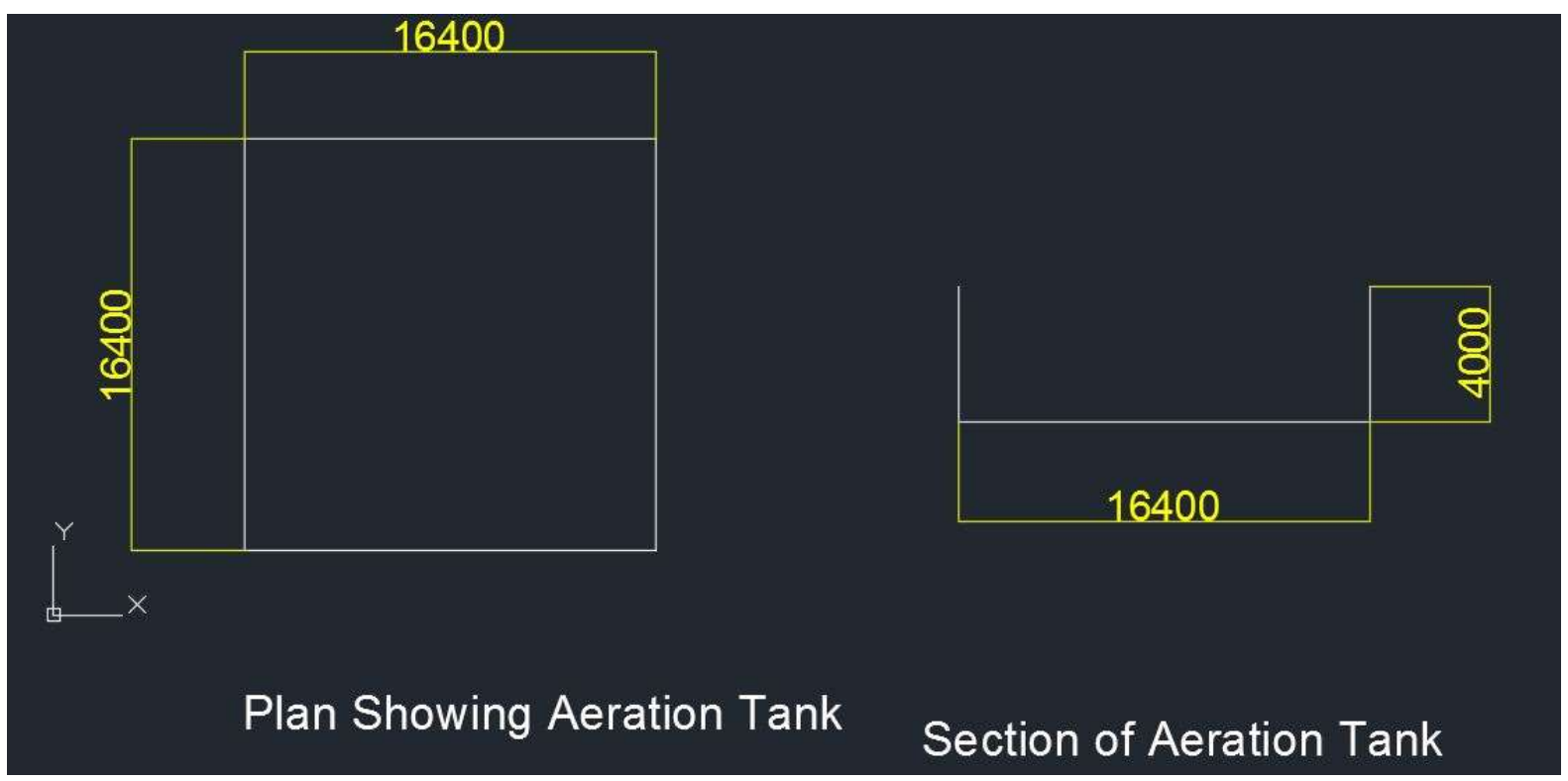

Figure 47: Plan Showing Aeration Tank 


\section{0}

Sludge Scrapper Arm

Outlet Sludge

Inlet Sludge

Gravity Thickener

Figure 48: Section showing Gravity Thickener

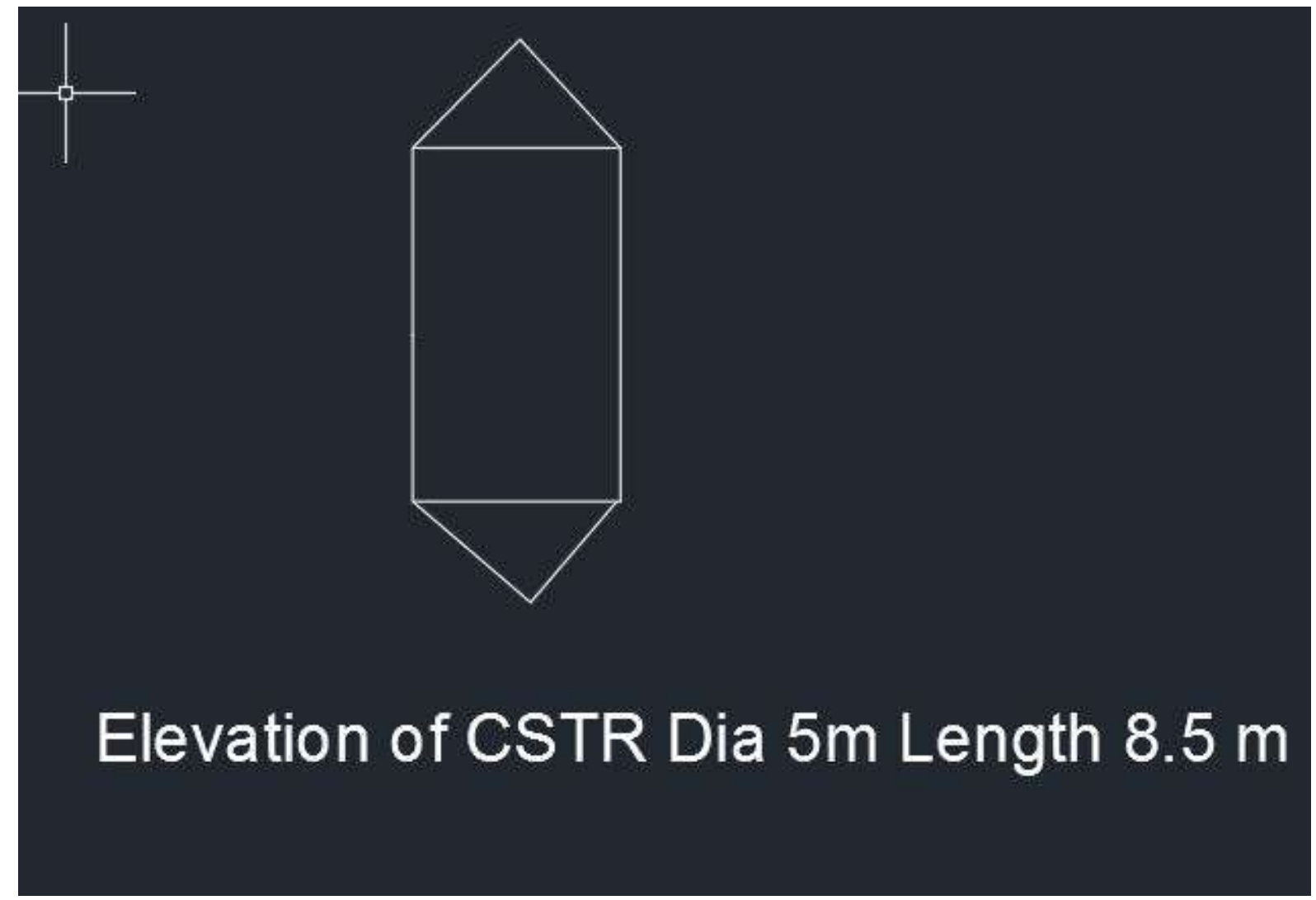

Figure 49: Elevation CSTR 


\subsection{Hydraulic Diagram of WWTP (without Primary Sedimentation)}

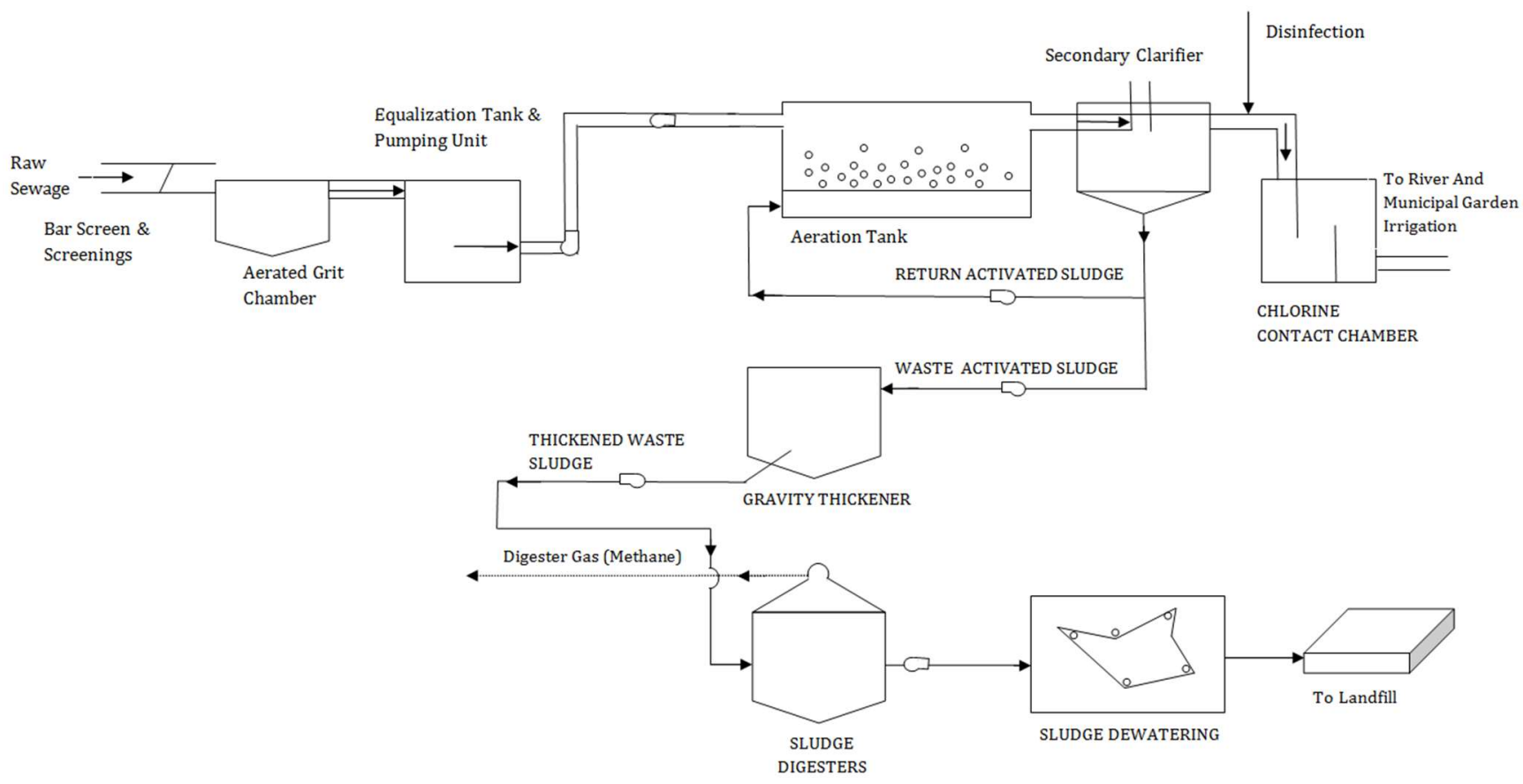

Figure 50: Hydraulic Flow Diagram 


\section{Establishing the Percent Capital Cost Savings Using the Technique of Parametric Estimation-}

\subsection{Parametric Estimation Concept \& Formulation-}

A parametric estimating model is a mathematical representation of cost relationships that provide a logical and predictable correlation between the physical or functional characteristics of a project (plant, process system, etc.) and its resultant cost [4]. A parametric estimate is comprised of cost estimating relationships and other parametric estimating functions that provide logical and repeatable relationships between independent variables (such as design parameters or physical characteristics) and the dependent variable (cost). The independent variables are known as cost drivers, and typically may be physical, performance, or operational characteristics associated with the project to be estimated.

Capacity factor and equipment factors estimates are simple examples of parametric estimates.

Parametric estimating provides several advantages as an estimating technique. Parametric estimates are:

- Efficient: They not only allowing estimates to be prepared in much less time than required by more detailed techniques, but require less engineering and level of project definition to support the estimate.

- Objective: Parametric models require quantitative inputs that are linked to algorithms providing quantitative outputs. All costs are traceable.

- Consistent: If two estimators input the same values for parameters, they will get the same resulting cost. Parametric models also provide a consistent estimate format and estimate documentation.

- Flexible: Parametric models provide costs for a range of input values, extrapolating to derive costs for projects of a different size or nature than you may have history for. The models can be easily adjusted to provide cost sensitivity analysis for proposed design changes. 
- Defensible: The models highlight the design parameters used, and can provide key statistical relationships and metrics for comparison with other projects.

Parametric estimating is the process of estimating cost by using mathematical equations that relate cost to one or more physical or performance variables associated with the item being estimated (Wyskida-Steward ). Used in its simplest form, a unit estimate that predicts the cost of a building based on its square footage is a parametric estimate as it relates the cost of the building to one physical variable - the square footage. As an example of a unit cost estimate consider the following (AACE International, 2005) (AACE International, 2011)

Practical cost data for similar period

Table 14: Building Costs with Area in Sqft

\begin{tabular}{|l|l|l|l|}
\hline Project Name & Cost \$ & Sq-feet & $\begin{array}{l}\text { Functional \& } \\
\text { Quality }\end{array}$ \\
\hline Project 1 & 100,000 & 2,000 & Similar \\
\hline Project 2 & 145,000 & 3,000 & Similar \\
\hline Project 3 & 190,000 & 4,000 & Similar \\
\hline Project 4 & 225,000 & 5,000 & Similar \\
\hline Total & 660,000 & 14,000 & \\
\hline
\end{tabular}

Rate per Sqft $=660,000 / 14000$

$$
=\$ 47.14 / \mathrm{Sqft}
$$

Extending the concept of parametric estimation to the capital cost of the wastewater treatment plant.

We assume that the capital cost of the WWTP is proportional to the combined volume of the various units in the WWTP.

It is based on the premises that the more the combined volume of the WWTP units with same functional and performance characteristics. The percent cost savings can be established by the following computations.

Capital cost (with Primary Sedimentation)

$=$ constant $*$ Volume of WWTP with Primary Sedimentation

Capital cost (Without Primary Sedimentation)

$=$ constant $*$ Combined Volume of WWTP without Primary Sedimentation 
Capital Cost Percent savings

$=$ Volume of WWTP with Primary Sedimentation/ Combined Volume of WWTP without Primary Sedimentation

\subsection{Computing the Volume of the Units with Primary Sedimentation}

Table 15: Computation Showing the Volume with Primary Sedimentation

\begin{tabular}{|l|r|r|r|r|r|}
\hline $\begin{array}{l}\text { Name of Treatment } \\
\text { Unit }\end{array}$ & Nos & D (m) & W (m) & L (m) & \multicolumn{2}{l|}{$\begin{array}{l}\text { Volume } \\
\text { Cum }\end{array}$} \\
\hline Equalization Tank & 1 & 5.8 & 26 & 52 & 7841.6 \\
\hline Screening Channel & 1 & 1.5 & 4.61 & 20 & 138.3 \\
\hline Aerated grit Chamber & 4 & 5.3 & 5 & 20 & 2120 \\
\hline $\begin{array}{l}\text { Primary Sedimentation } \\
\text { Tank }\end{array}$ & 1 & 3.5 & 26 & 106 & 9646 \\
\hline $\begin{array}{l}\text { Aeration Tank } \\
\text { (Activated sludge tank) }\end{array}$ & 4 & & & & \\
\hline Gravity Thickeners & 1 & 176.89 & 3 & 0.785 & 416.5 \\
\hline Secondary Clarifier & 4 & 1369 & 3.5 & 0.785 & 15045.3 \\
\hline CSTR & 1 & 25 & 8.5 & 0.785 & 166.8 \\
\hline Chlorination Tank & 1 & 11 & 11 & 4 & 484 \\
\hline \begin{tabular}{l} 
Total Volume \\
\hline
\end{tabular} & & & & & $38,994.60$ \\
\hline
\end{tabular}

\subsection{Computing the Volume of the Units with Primary Sedimentation}

Table 16: Computation Showing the Volume Without Primary Sedimentation

\begin{tabular}{|l|r|r|r|r|r|}
\hline $\begin{array}{l}\text { Name of Treatment } \\
\text { Unit }\end{array}$ & Nos & D (m) & W (m) & L (m) & \multicolumn{2}{l|}{$\begin{array}{l}\text { Volume } \\
\text { Cum }\end{array}$} \\
\hline Equalization Tank & 1 & 5.8 & 26 & 52 & 7841.6 \\
\hline Screening Channel & 1 & 1.5 & 4.61 & 20 & 138.3 \\
\hline Aerated grit Chamber & 4 & 5.3 & 5 & 20 & 2120 \\
\hline $\begin{array}{l}\text { Primary Sedimentation } \\
\text { Tank }\end{array}$ & 0 & 0 & 0 & 0 & 0 \\
\hline $\begin{array}{l}\text { Aeration Tank } \\
\text { (Activated sludge tank) }\end{array}$ & 4 & 4 & 16.4 & 16.4 & 4303.36 \\
\hline Gravity Thickeners & 1 & 146.41 & 3 & 0.785 & 344.79 \\
\hline Secondary Clarifier & 4 & 1369 & 3.5 & 0.785 & 15045.31 \\
\hline CSTR & 1 & 16 & 6.5 & 0.785 & 81.64 \\
\hline Chlorination Tank & 1 & 11 & 11 & 4 & 484 \\
\hline & & & & & $30,359.01$ \\
\hline
\end{tabular}




\subsection{Computing the Percent Capital Cost Savings}

Percent Capital Cost Reduction=100 * $(38,994.60-30,359.01) / 38,994.6$

\% Capital Cost Reduction

$22.15 \%$ 


\section{Conclusion}

It has been demonstrated by the design example that the capital cost of the Municipal wastewater treatment can be reduced by almost 22 percent, when we do not use the primary sedimentation tank. The capital cost savings are achieved by reduction in the volume of the sedimentation tank and there is minor increase in the size of the aeration tank. The size of the CSTR is also reduced due to the less volume of sludge produced from aeration tank. The model for cost estimation is based on the concept of parametric estimation, which has been long established and is being used widely in the cost calculations of the capital projects.

It can be seen that the there are many ways the operating performance of the municipal wastewater treatment plant can be achieved by carefully studying the problem and measuring the required parameters. The nutrients can be removed in many ways and this helps to maintain the clean environment as well as saving costs to produce those nutrients. Various methods of nutrients recovery are discussed. 


\section{References}

1. Activated sludge process description. Retrieved July 18, 2016, from http://nptel.ac.in/courses/105104102/Lecture\%2024.htm In-line Citation: (“Activated sludge process description," n.d.)

2. Cristina Ortega, K. K. (2009). Conceptual design of a waterwater treatment plant for municipality of Cotorro, province of Havana, Cuba. ASCE, 309-316.

3. Damian Kruk, M. T. (2015). Options for improved Nutrient Removal \& Recovery from Municipal Wastewater in Canadian Context. Manitoba : Canadian Municipal Water Consortium \& Canadian Water Network.

4. Federation of Canadian Municipalities and National Research Council. (2003). Wastewater Treatment Plant Optimization. Federation of Canadian Municipalities and National Research Council.

5. Kumar, K. S. (2011). Computer Aided Design of Wastewater Treatment Plant with Activated Sludge Process. International mJournal of Engineering Science \& Technology, 3348-3356.

6. Ministry of Enviornment -Ontario. (2008). Design Guidelines for Sewage Works 2008. Ontario: Ministry of Enviornment.

7. Lecture notes: Wastewater Treatment by Dr. Elsayed Elbeshbishy.-2016

8. Bruce E. Logan, Slawomir W. Hermanowicz and Denny S. Parker. A Fundamental Model for Trickling Filter Process Design. Journal (Water Pollution Control Federation), Vol. 59, No. 12 (Dec., 1987), pp. 1029-1042

9. John R. Harrison and Glen T. Daigger. A Comparison of Trickling Filter Media. Journal (Water Pollution Control Federation). Vol. 59, No. 7 (Jul., 1987), pp. 679-685

10. Njenga Mburu, Sylvie M. Tebitendwa, Johan J.A. van Bruggen, Diederik P.L. Rousseau, Piet N.L. Lens. Performance comparison and economics analysis of waste stabilization ponds and horizontal subsurface flow constructed wetlands treating domestic wastewater: A case study of the Juja sewage treatment works. Journal of Environmental Management, Volume 128, 15 October 2013, Pages 220-225

11. Aloyce W. Mayo, Muslim Abbas. Removal mechanisms of nitrogen in waste stabilization ponds. Physics and Chemistry of the Earth, Parts A/B/C, Volumes 72-75, 2014, Pages 7782 
12. Argelier, S., Delgenes, J., \& Moletta, R. (1998). Design of acidogenic reactors for the anaerobic treatment of the organic fraction of solid food waste. Bioprocess Engineering, 18(4), 309-315

13. Chanakya, H., Borgaonkar, S., Rajan, M., \& Wahi, M. (1992). Two-phase anaerobic digestion of water hyacinth or urban garbage. Bioresource Technology, 42(2), 123-131.

14. Demirel, B., \& Yenigün, O. (2002). Two-phase anaerobic digestion processes: A review. J. Chem. Technol. Biotechnol. Journal of Chemical Technology \& Biotechnology, 77(7), 743-755.

15. Demirer, G., \& Chen, S. (2005). Two-phase anaerobic digestion of unscreened dairy manure. Process Biochemistry, 40(11)

16. Mata-Alvarez, J., Macé, S., \& Llabrés, P. (2000). Anaerobic digestion of organic solid wastes. An overview of research achievements and perspectives. Bioresource Technology, 74(1), 3-16.

17. Metcalf \& Eddy. Wastewater Engineering: Treatment and Reuse; ISBN 13:9780070418783; McGraw-Hill Professional, 2002; $4^{\text {th }}$ edition

18. Pavlostathis, S. G., \& Giraldo-Gomez, E. (1991). Kinetics of anaerobic treatment: A critical review. Critical Reviews in Environmental Control, 21(5-6), 411-490.

19. Tsonis, S. P., \& Grigoropoulos, S. G. (1993). Water Science and Technology (Vol. 28, pp. 35-44).

20. Haandel, A. C., \& Lettinga, G. (1994). Anaerobic sewage treatment: A practical guide for regions with a hot climate. Chichester: J. Wiley.

21. Ward, A. J., Hobbs, P. J., Holliman, P. J., \& Jones, D. L. (2008). Optimisation of the anaerobic digestion of agricultural resources. Bioresource Technology, 99(17), 7928-7940.

22. Recommended Practice 10S-90, "Cost Engineering Terminology", AACE International 2016

23. Recommended Practice 17R-97, "Cost Estimate Classification”, AACE International -2011

24. Recommended Practice 18R-97, "Cost Estimate Classification - As Applied in Engineering, Procurement, and Construction for the Process Industries", AACE International -2005

25. Parametric Cost Estimating Handbook, NASA -2008

26. Black, Dr J. H., “Application of Parametric Estimating to Cost Engineering”, 1984 AACE Transactions, AACE International, 1984

27. Dysert, L. R., "Developing a Parametric Model for Estimating Process Control Costs", 1999 AACE 